\title{
Interventions to reduce preterm birth and stillbirth, and improve outcomes for babies born preterm in low- and middle-income countries: A systematic review
}

\author{
Elizabeth Wastnedge ${ }^{1 *}$, Donald Waters ${ }^{1 *}$, Sarah R \\ Murray ${ }^{1}$, Brian McGowan ${ }^{1}$, Effie Chipeta ${ }^{2}$, Alinane \\ Linda Nyondo-Mipando ${ }^{3}$, Luis Gadama ${ }^{4}$, Gladys \\ Gadama ${ }^{4}$, Martha Masamba ${ }^{4}$, Monica Malata ${ }^{2}$, Frank \\ Taulo $^{4}$, Queen Dube ${ }^{5}$, Kondwani Kawaza ${ }^{5}$, Patricia \\ Munthali Khomani ${ }^{6}$, Sonia Whyte ${ }^{1}$, Mia Crampin ${ }^{7}$, \\ Bridget Freyne ${ }^{6,8}$, Jane E Norman ${ }^{9}$, Rebecca M \\ Reynolds $^{1,10}$; DIPLOMATIC Collaboration
}

\footnotetext{
${ }^{1}$ Medical Research Council Centre for Reproductive Health, University of Edinburgh, Queen's Medical Research Institute, Edinburgh, UK

${ }^{2}$ Centre for Reproductive Health, College of Medicine, University of Malawi, Blantyre, Malawi

${ }^{3}$ Department of Health Systems \& Policy, School of Public Health and Family Medicine, College of Medicine, University of Malawi, Blantyre, Malawi

${ }^{4}$ Department of Obstetrics \& Gynaecology, College of Medicine, University of Malawi, Blantyre, Malawi

${ }^{5}$ Department of Paediatrics, College of Medicine, University of Malawi, Blantyre, Malawi

${ }^{6}$ Malawi-Liverpool Wellcome Trust Research Program, Blantyre, Malawi

${ }^{7}$ Malawi Epidemiology and Intervention Research Unit, Lilongwe, Malawi

${ }^{8}$ Institute of Infection \& Global Health, University of Liverpool, Liverpool, UK

${ }^{9}$ Faculty of Health Sciences, University of Bristol, Bristol, UK

${ }^{10}$ Centre for Cardiovascular Science, University of Edinburgh,

Queen's Medical Research Institute, Edinburgh, UK

*These authors contributed equally.
}

\section{Correspondence to:}

Professor Rebecca Reynolds

Centre for Cardiovascular Science

University of Edinburgh

Queen's Medical Research Institute

Edinburgh

UK EH16 4TJ

Rebecca.reynolds@ed.ac.uk
Background Reducing preterm birth and stillbirth and improving outcomes for babies born too soon is essential to reduce under-5 mortality globally. In the context of a rapidly evolving evidence base and problems with extrapolating efficacy data from high- to low-income settings, an assessment of the evidence for maternal and newborn interventions specific to lowand middle-income countries (LMICs) is required.

Methods A systematic review of the literature was done. We included all studies performed in LMICs since the Every Newborn Action Plan, between 2013 - 2018, which reported on interventions where the outcome assessed was reduction in preterm birth or stillbirth incidence and/or a reduction in preterm infant neonatal mortality. Evidence was categorised according to maternal or neonatal intervention groups and a narrative synthesis conducted.

Results 179 studies (147 primary evidence studies and 32 systematic reviews) were identified in 82 LMICs. 81 studies reported on maternal interventions and 98 reported on neonatal interventions. Interventions in pregnant mothers which resulted in significant reductions in preterm birth and stillbirth were (i) multiple micronutrient supplementation and (ii) enhanced quality of antenatal care. Routine antenatal ultrasound in LMICs increased identification of fetal antenatal conditions but did not reduce stillbirth or preterm birth due to the absence of services to manage these diagnoses. Interventions in pre-term neonates which improved their survival included (i) feeding support including probiotics and (ii) thermal regulation. Improved provision of neonatal resuscitation did not improve pre-term mortality rates, highlighting the importance of post-resuscitation care. Community mobilisation, for example through community education packages, was found to be an effective way of delivering interventions. 
Conclusions Evidence supports the implementation of several low-cost interventions with the potential to deliver reductions in preterm birth and stillbirth and improve outcomes for preterm babies in LMICs. These, however, must be complemented by overall health systems strengthening to be effective. Quality improvement methodology and learning health systems approaches can provide important means of understanding and tackling implementation challenges within local contexts. Further pragmatic efficacy trials of interventions in LMICs are essential, particularly for interventions not previously tested in these contexts.

Despite major global improvements in maternal and neonatal health during the Millennium Development Goals era, unacceptably high levels of preventable morbidity and mortality remain in many areas of the world [1]. Reductions in neonatal mortality (deaths within the first 28 days of life) have lagged behind those of overall mortality in children under 5 years of age, and as a result neonatal mortality accounts for $45 \%$ of total under-5 mortality worldwide [2]. Prematurity and associated complications are now the most frequent cause of death in all children younger than 5. Improvements in newborn survival have been slower in sub-Saharan Africa with current trends suggesting it will take over a century to achieve rates of newborn survival comparable to North America or Europe [3]. Sub-Saharan Africa has the highest stillbirth rates of any region, an under-recognised and neglected global public health issue responsible for 2.6 million third trimester fetal deaths worldwide in 2015 [4].

Despite evidence suggesting that $71 \%$ of neonatal deaths could be averted through scale-up of existing interventions, interventional studies in low-resource settings are limited [5]. This is reflected in the WHO guidelines on maternal and newborn care, which are derived primarily from studies done in high-income settings [6-8]. Extrapolation of efficacy estimates between settings is problematic as seen in the Antenatal Corticosteroids Trial (ACT) [9] and Fluid Expansion As Supportive Therapy (FEAST) trials [10,11]. There is therefore a major requirement for further efficacy studies of many interventions in low- and middle-income countries. In addition to this, there is an ongoing need for dissemination of current research findings in these settings in order to target future research appropriately.

This review presents the current evidence from studies done in LMICS over the last five years. We included studies or systematic reviews which reported on interventions targeted at (i) the prevention of preterm birth and stillbirth and (ii) decreasing mortality in preterm and low birth weight infant and ill newborns. This review aims to update existing guidance from the Every Newborn Action Plan [6-8] and report on the latest evidence from recent studies.

\section{METHODS}

A systematic literature review was done for studies published between (January 2013-May 2018) which reported on interventions in both mothers and infants from LMICs with the outcomes of 1) reducing preterm birth incidence 2) reducing stillbirth incidence 3) reducing neonatal mortality in preterm, low-birth weight, or unwell infants. The review adhered to MOOSE and PRISMA guidelines for reporting of systematic reviews and was pre-registered with Prospero (CRD42018099173). Key outcomes were defined as following: stillbirth was defined as baby born without signs of life after 28 weeks gestation; preterm birth was defined as Baby born before 36 weeks gestation; neonatal mortality was defined as death of baby born live, before 28 days of age [12].

MEDLINE, EMBASE, Web of Science, LILACS, CINAHL, Global health, MIDIRS, and the Cochrane Library were searched using keywords related to the above outcomes and limited to LMICs as defined by World Bank groupings [13]. The search was time-limited in order to build on previous reviews published in 2014 as part of the Lancet Every Newborn Series [5]. The keyword searches were done separately for maternal and neonatal interventions. Selected studies were screened by two reviewers (EW, DW). Inclusion criteria were: intervention studies published 2013-2018 in pregnant women or preterm newborns reporting on outcomes of preterm birth, stillbirth or neonatal mortality conducted in LMIC (or systematic reviews reporting $>50 \%$ LMIC data or providing LMIC subgroup analysis. Accepted study designs were RCTs, cohort studies, case/ control studies or before/after studies based in either community or hospital settings on both singleton and multiple pregnancies. Studies were excluded if they did not adequately report sample size calculation, or if they reported on wider public health interventions not exclusively aimed at pregnant women. Editorials, commentaries, reviews, conference abstracts and trial protocols were excluded, as were studies not published in the English language. 


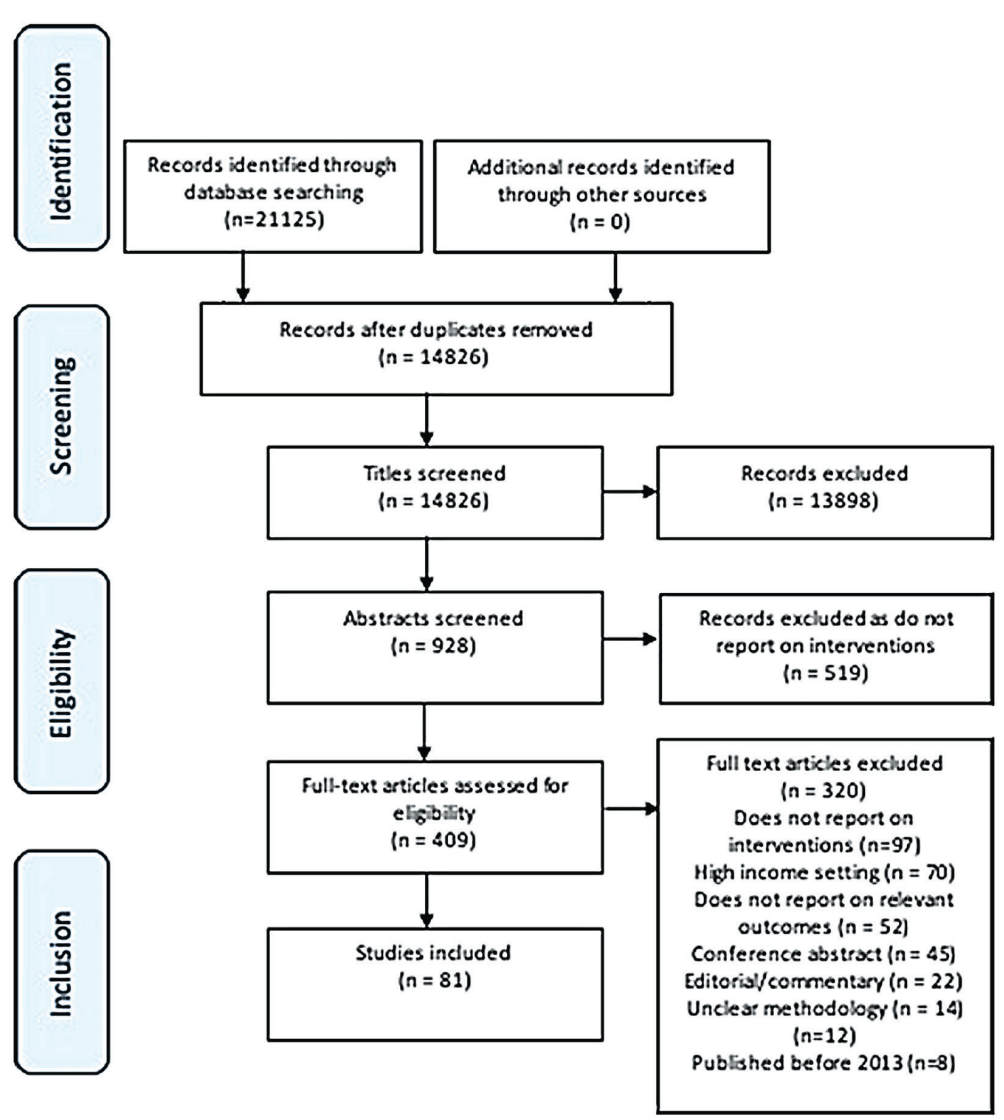

Figure 1. PRISMA flow diagram for maternal intervention study selection.

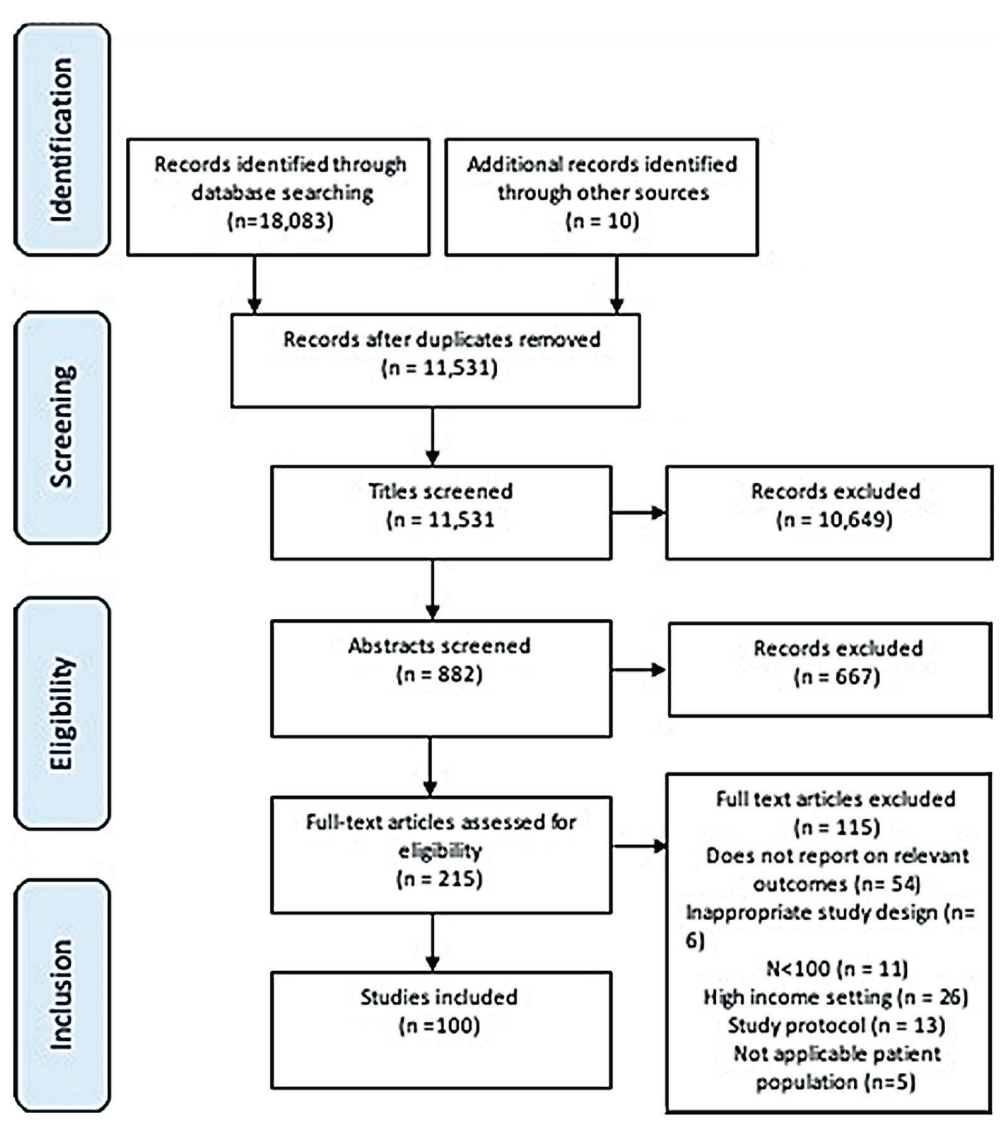

Figure 2. PRISMA flow diagram for neonatal intervention study selection.
Reference lists from relevant articles were also searched. Details of the search strategy can be found in Table S1 in the Online Supplementary Document. The PRISMA flow diagrams of search strategies for maternal interventions and neonatal interventions can be seen in Figure 1 and Figure 2.

In light of the results from the ACT trial showing potential harm from antenatal corticosteroids in LMICs, and the pending publication of the WHO ACTION trials [14], we excluded studies related to antenatal corticosteroids and preterm birth prevention [15].

\section{Evidence synthesis}

All studies which met these criteria were entered into an evidence gap map which is a visual representation of the studies in each area, demonstrating the volume of evidence in each area [16]. antenatal and delivery care (Table 1), lifestyle interventions (Table 2), health systems, training and guidelines (Table 3), pharmacological interventions (Table 4), nutritional supplements (Table 5), and community groups (Table 6). Neonatal interventional studies were grouped as: infection prevention and treatment (Table 7), respiratory support (Table 8), cardiovascular support (Table 9), health systems, training and guidelines (Table 10), feeding and nutrition (Table 11) and community mobilization (Table 12). Complex interventions were disaggregated where possible and the relevant data for each of the above groups was assessed independently.

\section{RESULTS}

A total of 81 studies of maternal interventions (68 implementation studies and 13 systematic reviews) were included in analysis. Fifty-five studies reported on data from Sub-Saharan Africa, 25 from South Asia, 20 from East Asia and Pacific, 15 from the Middle East and North Africa, 12 from Latin America and the Caribbean and 2 from Europe and Central Asia.

Ninety-eight studies of neonatal interventions (79 implementation studies, 19 systematic reviews) were included in analyses. 36 reported data from Sub-Saharan Africa, 35 from South Asia, 12 from East Asia and Pacific, 10 from the Middle East and North Africa, 14 from Latin America and the Caribbean, and 12 from Europe and Central Asia.

\section{Maternal interventions}

Tables 2-7 show the study characteristics and details of the maternal interventions. 
Table 1. Maternal interventions - characteristics of individual studies (antenatal and delivery care)

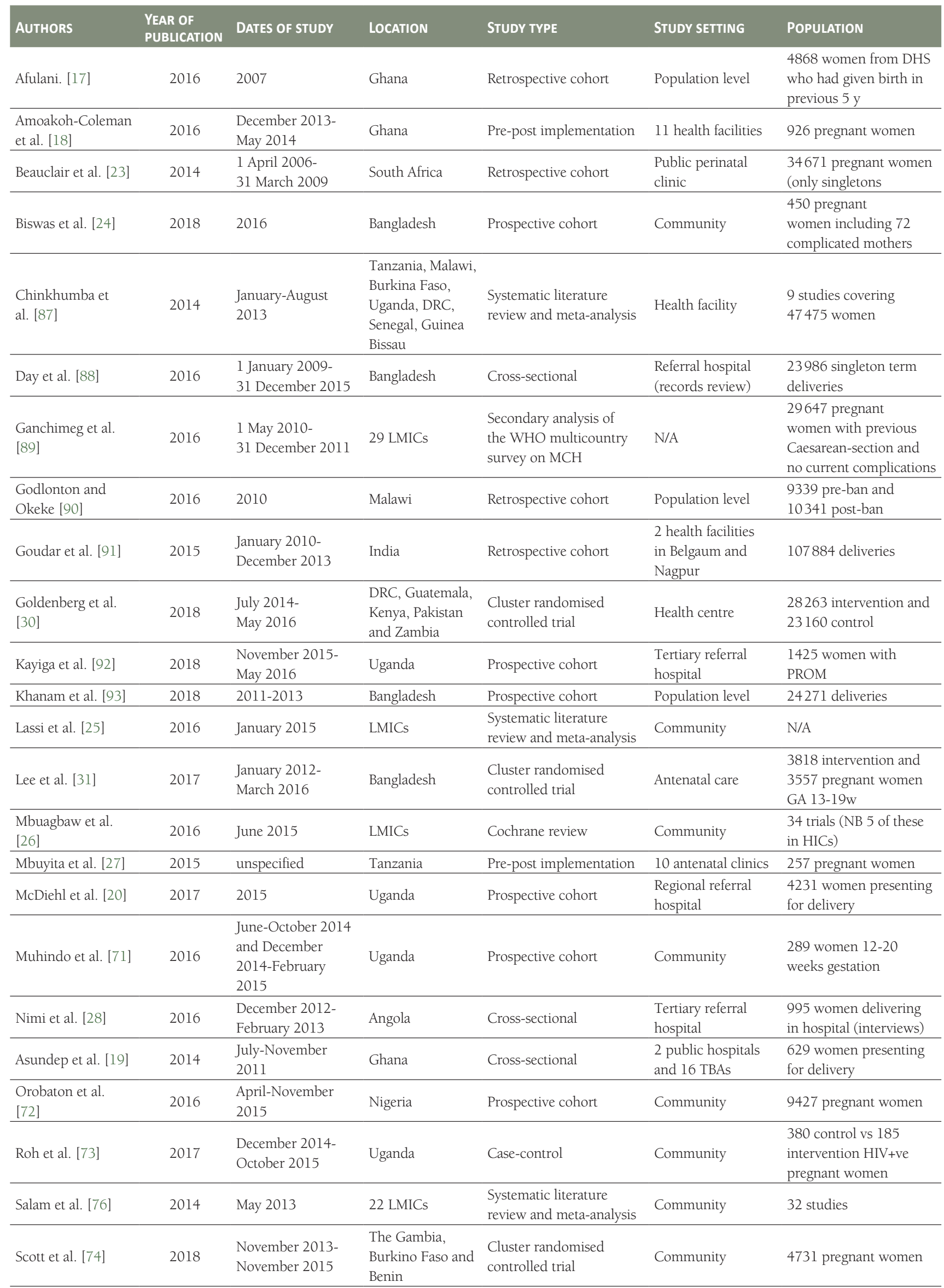


Table 2. Maternal interventions- characteristics of individual studies (lifestyle)

\begin{tabular}{|c|c|c|c|c|c|c|}
\hline AUTHORS & $\begin{array}{l}\text { YEAR OF } \\
\text { PUBLICATION }\end{array}$ & DATES OF STUDY & LOCATION & STUDY TYPE & STUDY SETTING & POPULATION \\
\hline $\begin{array}{l}\text { Alexander et al. } \\
{[70]}\end{array}$ & 2018 & $\begin{array}{l}\text { June 2013-October } \\
2015\end{array}$ & Nigeria & $\begin{array}{l}\text { Randomised control } \\
\text { trial }\end{array}$ & Community & $\begin{array}{l}324 \text { pregnant women } \\
\text { (162 intervention and } 162 \\
\text { control) }\end{array}$ \\
\hline Wang et al. [68] & 2017 & $\begin{array}{l}\text { December 2014- } \\
\text { July } 2016\end{array}$ & China & $\begin{array}{l}\text { Randomised control } \\
\text { trial }\end{array}$ & Antenatal care & $\begin{array}{l}300 \text { singleton women at GA } \\
10 \text { weeks with } \mathrm{BMI}>24\end{array}$ \\
\hline Wang et al. [69] & 2015 & $\begin{array}{l}20 \text { June-30 } \\
\text { November } 2013\end{array}$ & China & Retrospective cohort & Antenatal care & $\begin{array}{l}2750 \text { pregnant women with } \\
\text { GDM. } 74.9 \% \text { underwent } \\
\text { intervention }\end{array}$ \\
\hline
\end{tabular}

Table 3. Maternal interventions- characteristics of individual studies (health systems, training and guidelines)

\begin{tabular}{|c|c|c|c|c|c|c|}
\hline AUTHORS & $\begin{array}{l}\text { YEAR OF } \\
\text { PUBLICATION }\end{array}$ & DATES OF STUDY & LOCATION & STUDY TYPE & STUDY SETTING & POPULATION \\
\hline $\begin{array}{l}\text { Amoakoh-Coleman } \\
\text { et al. [18] }\end{array}$ & 2016 & $\begin{array}{l}\text { December 2013- } \\
\text { May } 2014\end{array}$ & Ghana & $\begin{array}{l}\text { Pre-post } \\
\text { implementation }\end{array}$ & 11 health facilities & 926 pregnant women \\
\hline Asare et al. [80] & 2017 & $\begin{array}{l}\text { January 2014- } \\
\text { May } 2016\end{array}$ & Ghana & $\begin{array}{l}\text { Pre-post } \\
\text { implementation }\end{array}$ & Teaching hospital & $\begin{array}{l}\text { Women with SCD } 158 \text { pre } \\
\text { and } 90 \text { post- intervention }\end{array}$ \\
\hline Ballard et al. [22] & 2016 & $\begin{array}{l}\text { May- December } \\
2014\end{array}$ & Ethiopia & $\begin{array}{l}\text { Cross-sectional } \\
\text { (questionnaires of } \\
\text { women who delive- } \\
\text { red in the past } 12 \\
\text { mo) }\end{array}$ & Community & $\begin{array}{l}4442 \text { women who had } \\
\text { delivered in previous } 12 \text { mo } \\
\text { (randomly selected) }\end{array}$ \\
\hline $\begin{array}{l}\text { Byaruhanga et al. } \\
\text { [81] }\end{array}$ & 2015 & $\begin{array}{l}\text { July 2012- } \\
\text { December } 2013\end{array}$ & Uganda & $\begin{array}{l}\text { Prospective equally } \\
\text { randomised clinical } \\
\text { trial }\end{array}$ & Teaching hospital & 1971 women in active labour \\
\hline Chomba et al. [85] & 2017 & $\begin{array}{l}\text { March 2005- } \\
\text { February } 2007\end{array}$ & $\begin{array}{l}\text { DRC, Guatemala, } \\
\text { Kenya, Pakistan } \\
\text { and Zambia }\end{array}$ & Prospective cohort & Community & $\begin{array}{l}22745 \text { controls and } 35074 \\
\text { intervention }\end{array}$ \\
\hline Gomez et al. [86] & 2018 & $\begin{array}{l}\text { March 2014- } \\
\text { February } 2017\end{array}$ & Ghana & $\begin{array}{l}\text { Cluster randomised } \\
\text { controlled trial }\end{array}$ & 40 hospitals & $\begin{array}{l}67659 \text { births post- } \\
\text { intervention }+38192 \text { births } \\
\text { pre-intervention }\end{array}$ \\
\hline Goudar et al. [91] & 2015 & $\begin{array}{l}\text { January 2010- } \\
\text { December } 2013\end{array}$ & India & Retrospective cohort & $\begin{array}{l}2 \text { health facilities } \\
\text { in Belgaum and } \\
\text { Nagpur }\end{array}$ & 107884 deliveries \\
\hline Maaløe et al. [77] & 2017 & $\begin{array}{l}1 \text { October 2014- } \\
31 \text { January } 2015\end{array}$ & Tanzania & $\begin{array}{l}\text { Pre-post } \\
\text { implementation }\end{array}$ & Referral hospital & $\begin{array}{l}\text { All labouring women in the } \\
\text { hospital- baseline }=3690 \\
\text { intervention }=3087\end{array}$ \\
\hline Mgaya et al. [78] & 2016 & $\begin{array}{l}\text { October 2013- } \\
\text { March } 2014 \\
\text { then July } 2015 \text { - } \\
\text { November } 2015\end{array}$ & Tanzania & $\begin{array}{l}\text { Pre-post } \\
\text { implementation }\end{array}$ & $\begin{array}{l}\text { National referral } \\
\text { hospital }\end{array}$ & $\begin{array}{l}260 \text { deliveries pre and } 250 \\
\text { post }\end{array}$ \\
\hline $\begin{array}{l}\text { Okonofua et al. } \\
\text { [79] }\end{array}$ & 2013 & $\begin{array}{l}\text { Baseline } \\
\text { Jan-May 2008, } \\
\text { April-June } 2009\end{array}$ & Nigeria & $\begin{array}{l}\text { Pre-post } \\
\text { implementation }\end{array}$ & 6 teaching hospitals & 219 women with eclampsia \\
\hline Pasha et al. [61] & 2013 & $\begin{array}{l}\text { March 2009- } \\
30 \text { September } 2011\end{array}$ & $\begin{array}{l}\text { Pakistan, } \\
\text { Kenya, Zambia, } \\
\text { Guatemala and } \\
\text { Argentina }\end{array}$ & $\begin{array}{l}\text { Cluster randomised } \\
\text { controlled trial }\end{array}$ & Community & $\begin{array}{l}55712 \text { intervention and } \\
54822 \text { control over } 106 \\
\text { clusters }\end{array}$ \\
\hline Patel et al. [218] & 2017 & $\begin{array}{l}1 \text { July 2012- } \\
30 \text { November } 2013\end{array}$ & India & Prospective cohort & Community & 7050 pregnant women \\
\hline $\begin{array}{l}\text { Srofenyoh et al. } \\
\text { [83] }\end{array}$ & 2013 & 2007-2009 & Ghana & Quality improvement & $\begin{array}{l}\text { Regional referral } \\
\text { hospital }\end{array}$ & $\begin{array}{l}\text { All women delivering in the } \\
\text { facility }\end{array}$ \\
\hline
\end{tabular}


Table 4. Maternal interventions- characteristics of individual studies (Pharmacological interventions)

\begin{tabular}{|c|c|c|c|c|c|c|}
\hline AUTHORS & $\begin{array}{l}\text { YEAR OF } \\
\text { PUBLICATION }\end{array}$ & DATES OF STUDY & LOCATION & STUDY TYPE & STUDY SETTING & POPULATION \\
\hline Bellad et al. [32] & 2018 & $\begin{array}{l}\text { October } 2013 \text { - } \\
\text { July } 2015\end{array}$ & India & $\begin{array}{l}\text { Randomised placebo- } \\
\text { controlled trial }\end{array}$ & Antenatal care & $\begin{array}{l}1727 \text { women GA } 13-20 \\
\text { weeks with vaginal } \mathrm{pH} \geq 5\end{array}$ \\
\hline Brizot et al. [98] & 2015 & $\begin{array}{l}1 \text { June } 2007- \\
31 \text { October } 2013\end{array}$ & Brazil & $\begin{array}{l}\text { Randomised placebo- } \\
\text { controlled double- } \\
\text { blinded }\end{array}$ & Single hospital & $\begin{array}{l}390 \text { twin pregnancies } 18- \\
22 \mathrm{w} \text { GA }\end{array}$ \\
\hline $\begin{array}{l}\text { Chagomerana et } \\
\text { al. [94] }\end{array}$ & 2017 & $\begin{array}{l}\text { April 2012- } \\
\text { November } 2015\end{array}$ & Malawi & Retrospective cohort & $\begin{array}{l}\text { Regional referral } \\
\text { hospital }\end{array}$ & $\begin{array}{l}3074 \text { HIV infected } \\
\text { pregnant women } \\
\text { delivering at }>27 \text { weeks } \\
\text { gestation }\end{array}$ \\
\hline Cluver et al. [218] & 2018 & $\begin{array}{l}\text { January 2016- April } \\
2017\end{array}$ & South Africa & $\begin{array}{l}\text { Randomised control } \\
\text { trial }\end{array}$ & Hospital & $\begin{array}{l}\text { Women with pre- } \\
\text { eclampsia } 26-37 w \text { GA. } \\
59 \text { intervention and } 60 \\
\text { placebo }\end{array}$ \\
\hline Day et al. [88] & 2016 & $\begin{array}{l}1 \text { January 2009- } \\
31 \text { December } 2015\end{array}$ & Bangladesh & Cross-sectional & $\begin{array}{l}\text { Referral hospital } \\
\text { (records review) }\end{array}$ & $\begin{array}{l}23986 \text { singleton term } \\
\text { deliveries }\end{array}$ \\
\hline Gupta et al. [33] & 2013 & $\begin{array}{l}\text { October } 2005- \\
\text { March } 2007\end{array}$ & India & $\begin{array}{l}\text { Randomised control } \\
\text { trial }\end{array}$ & Referral hospital & $\begin{array}{l}242 \text { women GA } 12-24 \text { w } \\
\text { with abnormal vaginal } \\
\text { flora }\end{array}$ \\
\hline Haghighi et al. [99] & 2017 & $\begin{array}{l}\text { December 2001- } \\
\text { November } 2012\end{array}$ & South Africa & $\begin{array}{l}\text { Randomised control } \\
\text { trial }\end{array}$ & Teaching hospital & $\begin{array}{l}315 \text { women with } \\
\text { threatened pre-term } \\
\text { labour (progesterone 159, } \\
\text { nifedipine 156) }\end{array}$ \\
\hline Jiang et al. [100] & 2016 & $\begin{array}{l}\text { November 2013- } \\
\text { July } 2015\end{array}$ & China & $\begin{array}{l}\text { Randomised control } \\
\text { trial }\end{array}$ & $\begin{array}{l}\text { County level } \\
\text { hospital }\end{array}$ & $\begin{array}{l}\text { Pregnant women }<20 \mathrm{w} \\
\text { GA } 232 \text { intervention } 234 \\
\text { control }\end{array}$ \\
\hline Lancaster et al. [96] & 2016 & $\begin{array}{l}12 \text { March 2001- } \\
6 \text { January } 2010\end{array}$ & $\begin{array}{l}\text { Uganda and } \\
\text { Zimbabwe }\end{array}$ & Prospective cohort & Community & $\begin{array}{l}160 \text { HIV infected pregnant } \\
\text { women }\end{array}$ \\
\hline Lee et al. [31] & 2017 & $\begin{array}{l}\text { January 2012- } \\
\text { March } 2016\end{array}$ & Bangladesh & $\begin{array}{l}\text { Cluster randomised } \\
\text { controlled trial }\end{array}$ & Antenatal care & $\begin{array}{l}3818 \text { intervention and } \\
3557 \text { pregnant women GA } \\
13-19 \mathrm{w}\end{array}$ \\
\hline Li et al. [34] & 2017 & $2001-2015$ & China & $\begin{array}{l}\text { Prospective cohort with } \\
\text { effect estimates based } \\
\text { on modelling }\end{array}$ & Antenatal care & $\begin{array}{l}2.8 \text { million pregnant } \\
\text { women screening for } \\
\text { syphylis, } 7149+\text { ve }\end{array}$ \\
\hline $\begin{array}{l}\text { Ndibazza et al. } \\
\text { [219] }\end{array}$ & 2010 & $\begin{array}{l}\text { April 2003- } \\
\text { November } 2005\end{array}$ & Uganda & $\begin{array}{l}\text { Randomised placebo- } \\
\text { controlled double- } \\
\text { blinded }\end{array}$ & Antenatal care & 2507 pregnant women \\
\hline $\begin{array}{l}\text { Ponmozhi et al. } \\
\text { [220] }\end{array}$ & 2017 & $\begin{array}{l}\text { December 2012- } \\
\text { August } 2014\end{array}$ & India & $\begin{array}{l}\text { Randomised double- } \\
\text { blind placebo- } \\
\text { controlled parallel arm } \\
\text { superiority trial }\end{array}$ & $\begin{array}{l}\text { Tertiary referral } \\
\text { hospital }\end{array}$ & $\begin{array}{l}100 \text { women below } 16 \mathrm{w} \\
\text { GA with any risk factors } \\
\text { for pre-eclampsia }\end{array}$ \\
\hline Rempis et al. [95] & 2017 & $\begin{array}{l}\text { February-December } \\
2013\end{array}$ & Uganda & Cross-sectional & District hospital & $\begin{array}{l}412 \text { mother-newborn } \\
\text { pairs }\end{array}$ \\
\hline Salam et al. [76] & 2014 & May 2013 & 22 LMICs & $\begin{array}{l}\text { Systematic literature } \\
\text { review and meta- } \\
\text { analysis }\end{array}$ & Community & 32 studies \\
\hline Unger et al. [75] & 2015 & $\begin{array}{l}\text { November 2009- } \\
\text { February } 2013\end{array}$ & $\begin{array}{l}\text { Papua New } \\
\text { Guinea }\end{array}$ & $\begin{array}{l}\text { Parallel group } \\
\text { randomised controlled } \\
\text { trial }\end{array}$ & Antenatal care & $\begin{array}{l}2021 \text { pregnant women } \\
<26 w \text { GA }\end{array}$ \\
\hline Westen et al. [97] & 2014 & $\begin{array}{l}\text { March 2008- } \\
\text { February } 2009\end{array}$ & Tanzania & $\begin{array}{l}\text { Randomised controlled } \\
\text { non-inferiority trial }\end{array}$ & 2 rural hospitals & $\begin{array}{l}176 \text { women requiring } \\
\text { Caesarean-section }\end{array}$ \\
\hline
\end{tabular}


Table 5. Maternal interventions- characteristics of individual studies (nutrition supplements)

\begin{tabular}{|c|c|c|c|c|c|c|}
\hline AUTHORS & $\begin{array}{l}\text { YEAR OF } \\
\text { PUBLICATION }\end{array}$ & DATES OF STUDY & LOCATION & STUDY TYPE & STUDY SETTING & POPULATION \\
\hline Bhutta et al. [148] & 2013 & N/A & LMICs & $\begin{array}{l}\text { Review including } \\
\text { evidence from the } \\
\text { literature and de novo } \\
\text { evidence }\end{array}$ & Community & Pregnant women \\
\hline Muriel et al. [36] & 2016 & $\begin{array}{l}\text { March 2010- } \\
\text { June } 2011\end{array}$ & India & Case-control & Teaching hospital & $\begin{array}{l}\text { Randomly selected wo- } \\
\text { men attending ANC-100 } \\
\text { intervention and } 100 \\
\text { control }\end{array}$ \\
\hline $\begin{array}{l}\text { Haider and Bhutta } \\
\text { [47] }\end{array}$ & 2017 & 11-Mar 2015 & LMICs & Cochrane review & Antenatal care & $\begin{array}{l}1437791 \text { pregnant } \\
\text { women in } 17 \text { studies }\end{array}$ \\
\hline Haider et al. [51] & 2013 & 31-May 2012 & LMICs & $\begin{array}{l}\text { Systematic literature } \\
\text { review and meta- } \\
\text { analysis }\end{array}$ & Antenatal care & $\begin{array}{l}12932 \text { pregnant women } \\
\text { in } 21 \text { studies }\end{array}$ \\
\hline He et al. [52] & 2016 & $2010-2015$ & China & Retrospective cohort & Antenatal care & $\begin{array}{l}1535066 \text { pregnant } \\
\text { women }\end{array}$ \\
\hline $\begin{array}{l}\text { Hemminki et al. } \\
\text { [53] }\end{array}$ & 2016 & $\begin{array}{l}\text { June 2007- } \\
\text { October } 2008\end{array}$ & Mozambique & $\begin{array}{l}\text { Randomised control } \\
\text { trial }\end{array}$ & 2 health centres & $\begin{array}{l}\text { Pregnant women: } 2142 \\
\text { intervention and } 2184 \\
\text { control }\end{array}$ \\
\hline Hossain et al. [54] & 2018 & $\begin{array}{l}\text { September 2010- } \\
\text { May } 2011\end{array}$ & Pakistan & $\begin{array}{l}\text { Randomised control } \\
\text { trial }\end{array}$ & $\begin{array}{l}\text { University teaching } \\
\text { hospital }\end{array}$ & 193 pregnant women \\
\hline $\begin{array}{l}\text { Janmohamad et } \\
\text { al. [55] }\end{array}$ & 2016 & Unspecified & Cambodia & $\begin{array}{l}\text { Cluster randomised } \\
\text { controlled trial }\end{array}$ & $\begin{array}{l}\text { Community ( } 75 \\
\text { villages) }\end{array}$ & $\begin{array}{l}333 \text { intervention and } 214 \\
\text { control pregnant women }\end{array}$ \\
\hline Kang et al. [56] & 2017 & $2007-2012$ & Tibet & Prospective cohort & $\begin{array}{l}2 \text { high altitude rural } \\
\text { communities }\end{array}$ & 1149 pregnant women \\
\hline Kiondo et al. [57] & 2014 & $\begin{array}{l}\text { November 2011- } \\
\text { June } 2012\end{array}$ & Uganda & $\begin{array}{l}\text { Randomised placebo- } \\
\text { controlled trial }\end{array}$ & $\begin{array}{l}\text { Tertiary referral } \\
\text { hospital }\end{array}$ & $\begin{array}{l}932 \text { women age } 15-42 \mathrm{GA} \\
12-22 \mathrm{w} \text { ( } 466 \text { intervention } \\
\text { and } 466 \text { placebo) }\end{array}$ \\
\hline Li et al. [37] & 2014 & $\begin{array}{l}\text { October 1993- } \\
\text { December } 1996\end{array}$ & $\begin{array}{l}\text { China }(2 \\
\text { provinces) }\end{array}$ & Prospective cohort & Antenatal care & $\begin{array}{l}207936 \text { singleton preg- } \\
\text { nancies from GA to } 20 \mathrm{w}\end{array}$ \\
\hline Liu et al. [38] & 2013 & $\begin{array}{l}\text { May 2006- } \\
\text { April } 2009\end{array}$ & China & $\begin{array}{l}\text { Randomised double- } \\
\text { blinded controlled trial }\end{array}$ & 5 counties & $\begin{array}{l}18775 \text { nulliparous } \\
\text { pregnancy women } \\
\text { without anaemia }\end{array}$ \\
\hline $\begin{array}{l}\text { McCauley et al. } \\
\text { [39] }\end{array}$ & 2016 & 30 March 2016 & LMICs & Cochrane review & Antenatal care & $\begin{array}{l}\text { Pregnant women in } 19 \\
\text { trials }\end{array}$ \\
\hline Mojibian et al. [40] & 2015 & $2010-2012$ & Iran & $\begin{array}{l}\text { Randomised control } \\
\text { trial }\end{array}$ & 2 prenatal clinics & 500 pregnant women \\
\hline Mosha et al. [41] & 2016 & $\begin{array}{l}\text { August 2001- } \\
\text { July } 2004\end{array}$ & Tanzania & Prospective cohort & Community & 7634 pregnant women \\
\hline Nossier et al. [42] & 2015 & $\begin{array}{l}\text { February 2007- } \\
\text { September } 2009\end{array}$ & Egypt & $\begin{array}{l}\text { Double-blind placebo- } \\
\text { controlled, parallel } \\
\text { group randomised trial }\end{array}$ & Antenatal care & 675 pregnant women \\
\hline Ota et al. [43] & 2015 & 31 October 2014 & LMICs & Cochrane review & Antenatal care & $\begin{array}{l}21 \text { RCTs including } \\
>17000 \text { women }\end{array}$ \\
\hline $\begin{array}{l}\text { Pena-Rosas et al. } \\
\text { [44] }\end{array}$ & 2015 & March 2012 & LMICs & $\begin{array}{l}\text { Systematic literature } \\
\text { review and meta- } \\
\text { analysis }\end{array}$ & Antenatal care & $\begin{array}{l}4072 \text { women (from } 18 \\
\text { trials) }\end{array}$ \\
\hline $\begin{array}{l}\text { Ramakrishnan et } \\
\text { al. [45] }\end{array}$ & 2016 & $\begin{array}{l}\text { November } 2011- \\
\text { September } 2013 \\
\end{array}$ & Vietnam & $\begin{array}{l}\text { Randomised double- } \\
\text { blinded controlled trial }\end{array}$ & Antenatal care & 1813 pregnant women \\
\hline Sablok et al. [46] & 2015 & 2010-2012 & India & $\begin{array}{l}\text { Randomised control } \\
\text { trial }\end{array}$ & $\begin{array}{l}\text { Tertiary referral } \\
\text { hospital }\end{array}$ & $\begin{array}{l}180 \text { pregnant women (60 } \\
\text { control, } 120 \text { intervention) }\end{array}$ \\
\hline Smith et al. [48] & 2017 & July 2015 & 14 LMICs & $\begin{array}{l}\text { Systematic literature } \\
\text { review and meta- } \\
\text { analysis }\end{array}$ & Antenatal care & 112953 women \\
\hline West et al. [49] & 2014 & $\begin{array}{l}4 \text { December } 2007- \\
30 \text { August } 2012\end{array}$ & Bangladesh & $\begin{array}{l}\text { Cluster randomised } \\
\text { double masked control } \\
\text { trial }\end{array}$ & Antenatal care & 44567 pregnancies \\
\hline Zheng et al. [50] & 2016 & $1999-2012$ & China & Prospective cohort & Community & $\begin{array}{l}231179 \text { deliveries seen in } \\
\text { 1st trimester (excluding } \\
\text { singletons weighing } \\
<1000 \mathrm{~g} \text { or }>5000 \mathrm{~g} \text { ) }\end{array}$ \\
\hline
\end{tabular}


Table 6. Maternal interventions- characteristics of individual studies (community groups)

\begin{tabular}{|c|c|c|c|c|c|c|}
\hline AUTHORS & $\begin{array}{l}\text { YEAR OF } \\
\text { PUBLICATION }\end{array}$ & DATES OF STUDY & LOCATION & STUDY TYPE & STUDY SETTING & POPULATION \\
\hline $\begin{array}{l}\text { Colbourn et al. } \\
\text { [58] }\end{array}$ & 2015 & $\begin{array}{l}1 \text { October } 2008- \\
31 \text { December } 2010\end{array}$ & Malawi & Prospective cohort & Community & 729 community groups \\
\hline Fottrell et al. [59] & 2016 & $\begin{array}{l}1 \text { January 2009- } \\
30 \text { June } 2011\end{array}$ & Bangladesh & $\begin{array}{l}\text { Cluster randomised } \\
\text { controlled trial }\end{array}$ & Community & 19301 pregnant women \\
\hline $\begin{array}{l}\text { Lassi and Bhutta } \\
\text { [29] }\end{array}$ & 2015 & May 2014 & $\begin{array}{l}\text { India, } \\
\text { Bangladesh, } \\
\text { Pakistan, Nepal, } \\
\text { China, Zambia, } \\
\text { Malawi, Tanzania, } \\
\text { South Africa, } \\
\text { Ghana }\end{array}$ & Cochrane review & Community & 26 studies \\
\hline Lassi et al. [25] & 2016 & January 2015 & LMICs & $\begin{array}{l}\text { Systematic literature } \\
\text { review and meta- } \\
\text { analysis }\end{array}$ & Community & N/A \\
\hline Lewycka et al. [63] & 2013 & 2005-2009 & Malawi & $\begin{array}{l}\text { Cluster randomised } \\
\text { controlled trial }\end{array}$ & Community & $\begin{array}{l}185888 \text { women with } 26262 \\
\text { births }\end{array}$ \\
\hline $\begin{array}{l}\text { Mbuagbaw et al. } \\
\text { [26] }\end{array}$ & 2016 & June 2015 & LMICs & Cochrane review & Community & $\begin{array}{l}34 \text { trials (NB } 5 \text { of these in } \\
\text { HICs) }\end{array}$ \\
\hline Pasha et al. [61] & 2013 & $\begin{array}{l}\text { March 2009- } \\
30 \text { September } 2011\end{array}$ & $\begin{array}{l}\text { Pakistan, } \\
\text { Kenya, Zambia, } \\
\text { Guatemala and } \\
\text { Argentina }\end{array}$ & $\begin{array}{l}\text { Cluster randomised } \\
\text { controlled trial }\end{array}$ & Community & $\begin{array}{l}55712 \text { intervention and } \\
54822 \text { control over } 106 \\
\text { clusters }\end{array}$ \\
\hline Prost et al. [65] & 2013 & N/A & $\begin{array}{l}\text { Bangladesh, } \\
\text { Malawi, India } \\
\text { and Nepal }\end{array}$ & $\begin{array}{l}\text { Systematic literature } \\
\text { review and meta- } \\
\text { analysis }\end{array}$ & Community & 119428 births over 7 trials \\
\hline Soubeiga et al. [66] & 2014 & December 2013 & $\begin{array}{l}\text { India, nepal, } \\
\text { Bangladesh, } \\
\text { Ghana, Malawi, } \\
\text { Pakistan, Brazil, } \\
\text { Argentina }\end{array}$ & $\begin{array}{l}\text { Systematic literature } \\
\text { review and meta- } \\
\text { analysis }\end{array}$ & Community & $\begin{array}{l}307018 \text { pregnant women } \\
\text { across } 14 \text { studies }\end{array}$ \\
\hline
\end{tabular}

Table 7. Neonatal interventions- characteristics of individual studies grouped by intervention type (infection prevention and treatment)

\begin{tabular}{|c|c|c|c|c|c|c|}
\hline AUTHORS & $\begin{array}{l}\text { YEAR OF } \\
\text { PUBLICATION }\end{array}$ & DATES OF STUDY & LOCATION & STUDY TYPE & STUDY SETTING & POPULATION \\
\hline Afjeh et al. [133] & 2016 & $\begin{array}{l}\text { July 2011- } \\
\text { June } 2012\end{array}$ & Iran & Prospective cohort & $\begin{array}{l}\text { Tertiary referral } \\
\text { perinatal centre }\end{array}$ & $\begin{array}{l}\text { All VLBW newborns admitted } \\
\text { to NICU that survived }>2 \mathrm{~W} \\
(\mathrm{~N}=145,104 / 145 \text { inborn })\end{array}$ \\
\hline $\begin{array}{l}\text { Banupriya et al. } \\
\text { [112] }\end{array}$ & 2017 & $\begin{array}{l}\text { May 2013- } \\
\text { November } 2015\end{array}$ & India & RCT & $\begin{array}{l}\text { Tertiary referral } \\
\text { centre }\end{array}$ & $\begin{array}{l}\text { Neonates aged }<28 \mathrm{~d} \text {, } \\
\text { GA }>31 \text { weeks, on significant } \\
\text { enteral feeds, biochemical or } \\
\text { microbioogical evidence of } \\
\text { infection }(\mathrm{N}=134) \text {. Excluded } \\
\text { if already on Abx for sepsis. }\end{array}$ \\
\hline $\begin{array}{l}\text { Cleminson et al. } \\
\text { [143] }\end{array}$ & 2016 & August 2015 & $\begin{array}{l}\text { India, Egypt, } \\
\text { Bangladesh, } \\
\text { Turkey, Iran, } \\
\text { Pakistan, Brazil }\end{array}$ & $\begin{array}{l}\text { Systematic literature } \\
\text { review \& meta- } \\
\text { analysis }\end{array}$ & $\begin{array}{l}\text { Health facilities and } \\
\text { community }\end{array}$ & $\begin{array}{l}1184 \text { infants. } 11 \text { trials ( } 9 \text { from } \\
\text { LMICs). }\end{array}$ \\
\hline Debes et al. [109] & 2013 & December 2011 & $\begin{array}{l}\text { Ghana, Nepal, } \\
\text { India }\end{array}$ & $\begin{array}{l}\text { Systematic literature } \\
\text { review \& meta- } \\
\text { analysis }\end{array}$ & $\begin{array}{l}\text { Health facilities and } \\
\text { community }\end{array}$ & $\begin{array}{l}18 \text { studies. } 3 \text { studies included } \\
\text { in mortality analyses. }\end{array}$ \\
\hline Dilli et al. [114] & 2015 & $\begin{array}{l}\text { June 2011- } \\
\text { June } 2014\end{array}$ & Turkey & RCT & $\begin{array}{l}5 \text { tertiary referral } \\
\text { centres }\end{array}$ & $\begin{array}{l}\text { VLBW infants with } G A<32 \\
\text { weeks and birthweight }<1500 \mathrm{~g} \\
(\mathrm{~N}=400) \text {. Neonates who } \\
\text { died in lst week of life were } \\
\text { excluded. }\end{array}$ \\
\hline $\begin{array}{l}\text { Erdermir et al. } \\
\text { [134] }\end{array}$ & 2015 & $\begin{array}{l}\text { September 2010- } \\
\text { September } 2012\end{array}$ & Turkey & $\mathrm{RCT}$ & $\begin{array}{l}\text { Tertiary referral } \\
\text { centre }\end{array}$ & $\begin{array}{l}\text { Preterm newborns }<35 \text { weeks } \\
\text { gestation and }<24 \text { old at time } \\
\text { of admission }(\mathrm{N}=197)\end{array}$ \\
\hline
\end{tabular}


Table 7. continued

\begin{tabular}{|c|c|c|c|c|c|c|}
\hline AUTHORS & $\begin{array}{l}\text { YEAR OF } \\
\text { PUBLICATION }\end{array}$ & DATES OF STUDY & LOCATION & STUDY TYPE & STUDY SETTING & POPULATION \\
\hline $\begin{array}{l}\text { Fernandez-Carro- } \\
\text { cera et al [116] }\end{array}$ & 2013 & $\begin{array}{l}\text { January 2007-June } \\
2010\end{array}$ & Mexico & RCT & $\begin{array}{l}\text { Tertiary referral } \\
\text { centre }\end{array}$ & $\begin{array}{l}\text { Preterm newborns }<1500 \mathrm{~g} \\
\text { BW who were admitted to } \\
\text { neonatal care }\end{array}$ \\
\hline $\begin{array}{l}\text { Guney-Varal et al. } \\
\text { [113] }\end{array}$ & 2017 & $\begin{array}{l}\text { "one year period"- } \\
\text { dates not reported }\end{array}$ & Turkey & $\mathrm{RCT}$ & $\begin{array}{l}\text { Tertiary referral } \\
\text { centre }\end{array}$ & $\begin{array}{l}\text { Infants }<33 \text { weeks } G A \text { and } \\
<1500 \mathrm{~g}(\mathrm{~N}=110)\end{array}$ \\
\hline Kaur et al. [117] & 2015 & $\begin{array}{l}\text { May 2012-July } \\
2013\end{array}$ & India & RCT & $\begin{array}{l}\text { Tertiary referral } \\
\text { centre }\end{array}$ & $\begin{array}{l}\text { Inborn neonates }<2000 \mathrm{~g} \\
\text { admitted to NICU in first } 12 \mathrm{~h} \\
\text { of birth with no maternal risk } \\
\text { factors for sepsis }(\mathrm{N}=130) \text {. } \\
\text { Neonates who developed } \\
\text { culture-proven sepsis within } \\
72 \mathrm{~h} \text { of life were excluded. }\end{array}$ \\
\hline $\begin{array}{l}\text { Hosseini et al. } \\
\text { [144] }\end{array}$ & 2017 & $\begin{array}{l}\text { January 2013- } \\
\text { June } 2015\end{array}$ & Iran & RCT & $\begin{array}{l}\text { Tertiary referral } \\
\text { centre }\end{array}$ & $\begin{array}{l}\text { Preterm infants with } \\
\text { birthweight }<1500 \mathrm{~g} \text { admitted } \\
\text { to NICU with suspected sepsis } \\
(\mathrm{N}=209)\end{array}$ \\
\hline Khan et al. [111] & 2015 & Not reported & $\begin{array}{l}\text { Bangladesh, } \\
\text { Philippines, } \\
\text { India, Ghana, } \\
\text { Mexico, Nepal, } \\
\text { Brazil }\end{array}$ & $\begin{array}{l}\text { Systematic literature } \\
\text { review \& meta- } \\
\text { analysis }\end{array}$ & $\begin{array}{l}\text { Health facilities and } \\
\text { community }\end{array}$ & 10 studies, 6 in LMICs. \\
\hline Li et al. [135] & 2015 & $\begin{array}{l}\text { January 2008- } \\
\text { December } 2013 \\
\text { (Retrospective: } \\
\text { Jan 2008-Dec 2010, } \\
\text { Prospective Jan } \\
\text { 2011-Dec 2013) } \\
\end{array}$ & China & Ambispective cohort & $\begin{array}{l}\text { Tertiary referral } \\
\text { centre }\end{array}$ & $\begin{array}{l}\text { All newborns admitted to } \\
\text { neonatology department with } \\
\text { TTN and GA between } 34 \text { and } \\
42 \text { weeks }(\mathrm{N}=1485) \text {. Excluded } \\
\text { if BW<2000g. }\end{array}$ \\
\hline $\begin{array}{l}\text { Massawe et al. } \\
\text { [130] }\end{array}$ & 2018 & $\begin{array}{l}\text { Pre: Sept 2014- } \\
\text { May 2015, } \\
\text { Post: June 2015- } \\
\text { June } 2017\end{array}$ & Tanzania & $\begin{array}{l}\text { Pre/post } \\
\text { implementation }\end{array}$ & $\begin{array}{l}\text { Multi-site: } 3 \text { tertiary } \\
\text { referral hospitals, } 1 \\
\text { district hospital }\end{array}$ & $\begin{array}{l}\text { Inpatient pregnant women } \\
\text { and inborn preterm neonates. } \\
\mathrm{N}=3496 \text { preterm babies ( } 543 \\
\text { pre-implementation, } 2953 \\
\text { post-implementation). }\end{array}$ \\
\hline $\begin{array}{l}\text { Nandhini et al. } \\
\text { [122] }\end{array}$ & 2016 & Not reported & India & $\mathrm{RCT}$ & $\begin{array}{l}\text { Tertiary referral } \\
\text { centre }\end{array}$ & $\begin{array}{l}\text { Enterally fed preterm neonates } \\
\text { GA } 28 \text { - } 34 \text { weeks and } \\
\text { BW }>1000 \mathrm{~g} \text {. }\end{array}$ \\
\hline Oncel et al. [115] & 2014 & $\begin{array}{l}\text { February 2012- } \\
\text { February } 2013\end{array}$ & Turkey & RCT & $\begin{array}{l}\text { Tertiary referral } \\
\text { centre }\end{array}$ & $\begin{array}{l}\text { Preterm infants } G A<33 \text { weeks } \\
\text { and birthweight }<1501 g \text { who } \\
\text { survived to feed enterally } \\
(\mathrm{N}=400)\end{array}$ \\
\hline $\begin{array}{l}\text { Panigrahi et al. } \\
\text { [103] }\end{array}$ & 2017 & Not reported & India & RCT & $\begin{array}{l}149 \text { randomly } \\
\text { chosen villages in } \\
1 \text { state }\end{array}$ & $\begin{array}{l}\text { All births identified in study } \\
\text { villages }(\mathrm{N}=4556) \text {. Excluded } \\
\text { neonates }<35 \text { weeks gestation } \\
\text { or }<2000 \mathrm{~g} \text { birthweight. }\end{array}$ \\
\hline Patel et al. [104] & 2018 & $\begin{array}{l}\text { Pre: December } \\
2013 \text {-October } 2014 . \\
\text { Post: November } \\
2014 \text {-December } \\
2015 .\end{array}$ & India & $\begin{array}{l}\text { Retrospective pre/ } \\
\text { post implementation }\end{array}$ & $\begin{array}{l}\text { Tertiary referral } \\
\text { centre }\end{array}$ & $\begin{array}{l}\text { Preterm infants }<35 \text { weeks } \\
\text { GA admitted to neonatal unit } \\
(\mathrm{N}=199 \text {, Pre: } 145 \text {, Post: } 44)\end{array}$ \\
\hline Pinto et al. [145] & 2013 & $\begin{array}{l}\text { Pre: January 2006- } \\
\text { December } 2007 . \\
\text { Post: January } 2008- \\
\text { December } 2008 .\end{array}$ & Brazil & $\begin{array}{l}\text { Pre/post } \\
\text { implementation }\end{array}$ & $\begin{array}{l}\text { Tertiary referral } \\
\text { centre }\end{array}$ & $\begin{array}{l}\text { Newborns }<1500 \mathrm{~g} \text { admitted } \\
\text { to NICU and commenced } \\
\text { on broad-spectrum Abx for } \\
\text { suspected sepsis ( } \mathrm{N}=136 \text {, Pre: } \\
91 \text {, Post: } 45) \text {. }\end{array}$ \\
\hline Salam et al. [146] & 2015 & $\begin{array}{l}\text { July } 2011- \\
\text { January } 2012\end{array}$ & Pakistan & RCT & $\begin{array}{l}\text { Tertiary referral } \\
\text { centre }\end{array}$ & $\begin{array}{l}\text { All infants }<37 \text { weeks GA with } \\
\text { birthweight }>749 \mathrm{~g} \text {. Excluded } \\
\text { if severe RDS, skin infection } \\
\text { or life-threatening congenital } \\
\text { abnormality }(\mathrm{N}=258)\end{array}$ \\
\hline
\end{tabular}


Table 7. continued

\begin{tabular}{|c|c|c|c|c|c|c|}
\hline AUTHORS & $\begin{array}{l}\text { YEAR OF } \\
\text { PUBLICATION }\end{array}$ & DATES OF STUDY & LOCATION & STUDY TYPE & STUDY SETTING & POPULATION \\
\hline Sankar et al. [137] & 2013 & Not reported & $\begin{array}{l}\text { Malawi, Egypt, } \\
\text { Nepal, Pakistan, } \\
\text { Brazil, South } \\
\text { Africa, India, } \\
\text { Zimbabwe }\end{array}$ & $\begin{array}{l}\text { Systematic literature } \\
\text { review \& meta- } \\
\text { analysis }\end{array}$ & $\begin{array}{l}\text { Health facilities and } \\
\text { community }\end{array}$ & $\begin{array}{l}9 \text { studies. } 5 \text { studies provided } \\
\text { data on all-cause mortality. }\end{array}$ \\
\hline
\end{tabular}

\begin{tabular}{|c|c|c|c|c|c|c|}
\hline Santana et al. [105] & 2017 & $\begin{array}{l}\text { August 2014- } \\
\text { October } 2015\end{array}$ & Brazil & Retrospective cohort & $\begin{array}{l}\text { Tertiary referral } \\
\text { centre }\end{array}$ & $\begin{array}{l}\text { All consecutive neoantes } \\
\text { GA<37 weeks born at study } \\
\text { site and admitted for at least } 5 \\
\text { d to NICU (N=300). Neonates } \\
\text { with "trans-placental infection } \\
\text { potential" excluded. }\end{array}$ \\
\hline Sazawal et al. [138] & 2016 & $\begin{array}{l}\text { May 2011- } \\
\text { August } 2014\end{array}$ & Zanzibar & RCT & Population level & $\begin{array}{l}\text { All newborn babies born on } \\
\text { island aged } 1 \mathrm{~h} \text { - } 48 \mathrm{~h} \text { without } \\
\text { congenital malformations } \\
(\mathrm{N}=36911)\end{array}$ \\
\hline Schmidt et al. [139] & 2018 & $\begin{array}{l}\text { Pre: } 2010-2012 . \\
\text { Post: October } 2013- \\
\text { July } 2016\end{array}$ & Lao & $\begin{array}{l}\text { Retrospective pre/ } \\
\text { post implementation }\end{array}$ & $\begin{array}{l}5 \text { provincial } \\
\text { hospitals with } \\
\text { highest mortality } \\
\text { rate }\end{array}$ & $\begin{array}{l}\text { Newborns admitted to } \\
\text { pediatric ward or NICU in } \\
\text { participating sites. }(\mathrm{N}=3889 \text {, } \\
\text { Pre } \mathrm{N}=1673 \text { Post } \mathrm{N}=2216)\end{array}$ \\
\hline Semrau et al. [147] & 2016 & Feb 2011-Jan 2013 & Zambia & RCT (cluster) & $\begin{array}{l}90 \text { community } \\
\text { heath facility-based } \\
\text { clusters (must } \\
\text { provide routine } \\
\text { antenatal services } \\
\text { and at least } 160 \\
\text { annual births in } \\
\text { catchment area. } 12 \\
\text { urban, } 78 \text { rural)) }\end{array}$ & $\begin{array}{l}\text { Pregnant women (Aged }>14 \text {, } \\
\text { in second or third trimester) } \\
\text { attending antenatal clinics or } \\
\text { identified during community } \\
\text { outreach activities ( } \mathrm{N}=42356)\end{array}$ \\
\hline Serce et al. [106] & 2013 & $\begin{array}{l}\text { October 2012- } \\
\text { November } 2011 .\end{array}$ & Turkey & RCT & $\begin{array}{l}\text { Tertiary referral } \\
\text { centre }\end{array}$ & $\begin{array}{l}\text { Preterm newborns admitted } \\
\text { to NICU }(\mathrm{GA}<33 \text { weeks, } \\
\text { birthweight }<1501 \mathrm{~g}) \text {. } \\
\text { Excluded if death occurred in } \\
\text { first } 24 \mathrm{~h}(\mathrm{~N}=208)\end{array}$ \\
\hline $\begin{array}{l}\text { Shabaan et al. } \\
\text { [140] }\end{array}$ & 2017 & $\begin{array}{l}\text { August 2013- } \\
\text { June } 2015\end{array}$ & Egypt & RCT & $\begin{array}{l}\text { Tertiary referral } \\
\text { centre }\end{array}$ & $\begin{array}{l}\text { Inborn and outborn neonates } \\
\text { with late-onset sepsis caused } \\
\text { by gram negative bacteria } \\
\text { sensitive to meropenem. } \\
\text { Excluded SGA neonates and } \\
\text { those with congenital infection } \\
(\mathrm{N}=102) \text {. }\end{array}$ \\
\hline Soofi et al. [141] & 2017 & $\begin{array}{l}\text { April 2009- } \\
\text { December } 2012\end{array}$ & Pakistan & RCT (cluster) & $\begin{array}{l}\text { Rural district with } \\
\text { population approx. } \\
0.56 \text { million. } \\
\text { Clustered into } 27 \\
\text { clusters served } \\
\text { by an individual } \\
\text { functional primary } \\
\text { care facility. }\end{array}$ & All households in study area \\
\hline $\begin{array}{l}\text { Van Niekerk et al. } \\
\text { [123] }\end{array}$ & 2015 & $\begin{array}{l}\text { July 2011- August } \\
2012\end{array}$ & South Africa & RCT & $\begin{array}{l}\text { Tertiary referral } \\
\text { centre }\end{array}$ & $\begin{array}{l}\text { HIV-exposed and HIV- } \\
\text { unexposed infants }<34 \text { weeks } \\
\text { GA anc }<1250 \mathrm{~g} \text { who were } \\
\text { breast-milk fed delivered in } \\
\text { study site }\end{array}$ \\
\hline Zhou et al. [142] & 2013 & $\begin{array}{l}\text { Pre: February } \\
\text { 2006-January } \\
\text { 2007. Partial } \\
\text { intervention: August } \\
\text { 2008-July 2009. } \\
\text { Full intervention: } \\
\text { January 2010- } \\
\text { December 2010 }\end{array}$ & China & $\begin{array}{l}\text { Pre/post } \\
\text { implementation }\end{array}$ & $\begin{array}{l}\text { Tertiary referral } \\
\text { centre }\end{array}$ & $\begin{array}{l}\text { All neonates who received } \\
\text { mechanical ventilation } \\
\text { for at least } 48 \text { h and were } \\
\text { hospitalized in NICU for at } \\
\text { least } 5 \mathrm{~d} \text { (N=491, Pre: } 106, \\
\text { Partial: } 169 \text {, Full: } 216)\end{array}$ \\
\hline
\end{tabular}




\section{Antenatal care}

Thirteen studies were identified reporting on the impact of antenatal care [17-28]. Five of these showed antenatal care was associated with a reduction in stillbirth $[17,20,22,25,26]$, two of which also showed reduction in neonatal mortality $[25,26]$, two studies found antenatal care reduced a composite outcome of stillbirth, preterm birth and low birthweight $[18,19]$, and four studies showed no significant difference in our outcomes $[21,23,24,27]$. A meta-analysis found antenatal care reduced both stillbirth (relative risk (RR) $=0.82,95 \%$ Confidence Interval $(\mathrm{CI})=0.73-0.93)$ and neonatal mortality $(\mathrm{RR}=0.80,95 \% \mathrm{CI}=0.72-0.8)$ [29].

Two studies evaluated the effect of introducing routine ultrasound scanning during antenatal care $[27,30]$. Neither found any improvement in stillbirth or preterm birth reduction, although both led to increased identification of fetal problems. This included a large cluster randomised controlled trial encompassing 51423 births, with stillbirth reduction ( $\mathrm{RR}=1.09,95 \% \mathrm{CI}=0.97-1.23)$ and neonatal mortality reduction $(\mathrm{RR}=0.99$, 95\% CI=0.86-1.14) [30].

\section{Genito-urinary infection management}

Three randomised-controlled trials reported on genito-urinary infection management, focussing on testing and treating for bacterial vaginosis during the second trimester [31-33]. Two of these trials found no significant difference in any outcomes[31,32] however one trial comparing bacterial vaginosis treatment vs placebo in women with abnormal vaginal flora found a significant reduction in preterm birth ( $\mathrm{RR}=1.65,95 \% \mathrm{CI}=1.04$ 2.63) [33]. A prospective cohort study in China evaluating the introduction of routine syphilis testing at first antenatal appointment, estimated a 39.4\% reduction in stillbirth and an $8.8 \%$ reduction in preterm birth [34].

\section{Nutritional supplements}

Twenty three studies reported on antenatal nutritional supplements [35-57]. Folic acid, zinc, calcium and multiple-micronutrient supplementation were all found to reduce preterm birth, whereas vitamin D, vitamin C and iron had no effect when given alone.

Three studies reported folic acid supplementation before conception and during pregnancy [37,50,52]. All found a significant reduction in preterm birth and this effect size was increased if taken from 3 months before the last menstrual period [52]. There were two studies with zinc supplementation, a Cochrane review on zinc alone showed a significant reduction in preterm birth rate ( $\mathrm{RR}=0.86,95 \% \mathrm{CI}=0.76-0.97)$ [43] and a $\mathrm{RCT}$ using zinc in a combination tablet with other multivitamins was associated with a reduction in stillbirth, preterm birth and early neonatal mortality [42]. There were two RCTs with vitamin D supplementation one of which found no significant effect[40] and the other found a reduction in preterm birth [46]. Vitamin C alone was found to have no difference in outcomes [57] however another study combining vitamin $\mathrm{E}$ and $\mathrm{C}$ observed preterm birth reduction [36]. Three studies used iron supplement regimes, pre-natal iron had no effect [51], neither did testing and treating anaemia [53]. Although low dietary iron was significantly associated with stillbirth and preterm birth $(\mathrm{RR}=0.12,95 \% \mathrm{CI}=0.036-0.377)$ and early neonatal mortality $(\mathrm{RR}=0.2395 \% \mathrm{CI}=0.15-0.35)$ [41], a systematic literature review comparing daily with intermittent iron found no significant difference in preterm birth (odds ratio $(\mathrm{OR})=1.82,95 \% \mathrm{CI}=0.75-4.4)$ [44]. Low dietary calcium was associated with increased preterm birth $(\mathrm{RR}=0.76,95 \% \mathrm{CI}=0.65-0.88)$ [41] and accordingly calcium supplementation was associated with a reduction in preterm birth $(\mathrm{RR}=0.76,95 \% \mathrm{CI}=0.60-0.97)$ [35].

Seven papers compared maternal micronutrient supplementation (MMN) with combined iron and folic acid supplementation $[35,38,45,47-49,56]$. All of these studies, including a Cochrane review, found significant reduction in both preterm birth and stillbirth with MMN compared with iron and folic acid alone. This effect was even more pronounced in women with anaemia or low body mass index (BMI) $[47,48]$.

\section{Community groups}

We identified nine papers including two systematic literature reviews and two Cochrane reviews evaluating the impact of community groups, all of which demonstrated significant reductions on stillbirth and neonatal mortality $[26,29,58-63]$. Three of these used community based intervention packages to deliver antenatal care- for example upscaling home visits by community health workers $[26,29,64]$. Seven papers reported on setting up women's groups as a means of providing peer counselling, community support, and increased prioritisation of women's health issues $[58,59,61,64-66]$. Improvements were seen in clean delivery practices, early breastfeeding, improved nutrition during pregnancy and improved health care seeking for neonates $[63,64]$. Having high population coverage and high proportions of pregnant women participating were both significant predictors of effect [67]. 


\section{Exercise}

Two RCTs assessed the effect of exercise during pregnancy in women who were overweight or had gestational diabetes mellitus (GDM) [68,69]. One found no reduction in preterm or stillbirth, but did find a significant reduction in GDM (22.0\% vs 40.6\%; P<0.001) [68]. The other involved both an exercise regime and dietary changes and this was associated with reduction in preterm birth ( $\mathrm{OR}=1.64,95 \% \mathrm{CI}=1.14-2.36)$ [69].

\section{Indoor air pollution}

One RCT trialled a low-emission ethanol cook stove (as opposed to traditional kerosene stoves) to determine the differential effects of ethanol vs kerosene cook stoves on pregnancy outcomes [70]. There were no significant difference in rates of preterm birth or stillbirth, but there was a significant increase in extended perinatal mortality (7.9\% vs 3.9\% P $=0.045)$ (stillbirth or death within first 28 days of life) associated with kerosene cook stoves.

\section{Malaria prevention}

Five trials involved malaria prevention during pregnancy [71-75]. Interventions included bed net provision plus indoor residual spraying (IRS), community scheduled screening and treatment plus intermittent preventative treatment (IPT) with Sulphadoxine Pyramethanine (SP) and all showed reductions in preterm or stillbirth. IRS led to decreases in neonatal mortality (17.2 vs $1.5 \% \mathrm{P}=0.006)$, stillbirth ( $7.5 \%$ vs $0 \% \mathrm{P}=0.03$ ) and placental parasitaemia [71]. These reductions were seen despite poor compliance with the full course of SP even with Community Health Worker (CHW) home delivery and Directly Observed Treatment Short-Course (DOTS), only $43 \%$ of women received the recommended 3 doses [72].

\section{Anti-helminthic therapy}

One systematic literature review reported on anti-helminthic treatment, focusing specifically on community-based eradication programmes [76]. This found no significant difference in preterm birth or stillbirth reduction $(\mathrm{RR}=1.54,95 \% \mathrm{CI}=:$ : 0.93-2.58).

\section{Guideline implementation}

Four studies evaluated the effect of guideline implementation for pregnancy care [18,77-79], and all had some beneficial effects on either preterm birth, stillbirth or neonatal mortality. The first study evaluated the impact of a guideline for the first ANC visit consisting of a checklist for health care workers. This led to a reduction in a composite outcome including stillbirth, preterm birth and low birthweight ( $\mathrm{RR}=0.72,95 \% \mathrm{CI}=0.65-0.93$ ) [18]. The second implemented a labour management guideline in the form of a pocket book ad wall posters, and observed a significant reduction in stillbirth $(\mathrm{RR}=0.66,95 \% \mathrm{CI}=0.53-0.82)$ [77]. Mgaya et al. found the introduction of a guideline for diagnosis and management of obstructed labour was followed by a reduction in perinatal mortality (stillbirth and neonatal mortality within the first 72 hours of life) from 16\% to 8.8\% $(P=0.01)$ [78]. Finally, Okonofua et al. found guidelines for diagnosis and management of eclampsia reduced the case fatality rate from 15.1 to $3.2 \%(P<0.001)$ [79].

\section{Health systems strengthening}

Five studies evaluated efforts to strengthen health systems [78,80-83]. A variety of methods were used though mainly included audit or quality improvement cycles where baseline data was collected and used to identify key areas of deficiency before prioritising and implementing intervention packages to address these [78,82]. In general, improvements were seen in outcome measures and this resulted from improvements in practice as well as more efficient and effective use of resources $[82,83]$. For example, a Ghanaian study trialling a series of QI bundles developed following a prolonged needs assessment, and observed a 36\% reduction in stillbirth [83]. A Tanzanian study ran a series of audit cycles and achieved significant reductions in stillbirth and perinatal death [84], and a Zimbabwean study found a series of changes in leadership and accountability led to a reduction in intrapartum stillbirth to almost zero [82].

\section{Staff training}

Nine implementation studies examined the impact of staff training on maternal and neonatal outcomes $[18,61,78-81,83,85,86]$. All studies reported some level of improvement in stillbirth, neonatal mortality or maternal mortality to varying degrees. Programmes involving repeated sessions reinforcing knowledge were 
more effective than one-off sessions $[79,86]$. Programmes were only effective if administrative authorities were involved from the outset $[79,86]$. Involving pregnant women in training and education was also found to improve outcomes in one study [85].

\section{Delivery care}

There were eight intervention studies about delivery care including one systematic literature review [22,87-93]. Four studies compared facility with home delivery or delivery with traditional birth attendant $[87,90,91,93]$. All studies, including a systematic literature review [87] found that facility delivery conferred worse outcomes both for the neonate and the mother with significantly higher rates of stillbirth and maternal mortality. The systematic literature review evaluated data from 9 studies from sub-Saharan Africa including 47475 women, and found no significant change in perinatal mortality between home and facility delivery $(\mathrm{OR} 1.21,95 \% \mathrm{CI}=$ 0.79-1.84) but did show a significant increase in maternal mortality [87]. Khanam et al. conducted a prospective cohort study in Bangladesh covering 24271 births and found a significant increase in perinatal mortality $(\mathrm{OR}=2.4,95 \% \mathrm{CI}=2.08-2.76)[93]$.

\section{Pharmacological interventions}

There were ten trials of pharmacological interventions for the reduction of preterm and stillbirth. Three studies investigated the impact of antiretroviral therapy (ART) [94-96]. One found no significant difference in rates of preterm birth in mothers receiving ART [95] and the other two found ART significantly reduced preterm birth $[94,96]$. This effect was increased if ART was started before conception [94]. One study compared single dose antibiotic prophylaxis to a multi-day course for routine C-section and found there was no significant difference in stillbirth or neonatal mortality between the two [97]. Vaginal progesterone for tocolysis in twin pregnancies was not found to increase gestational age at delivery [98], and a comparison of IM progesterone and nifedipine for threatened preterm labour found no significant change in either time to delivery or rates of Neonatal Intensive Care Unit (NICU) admission [99].

\section{Periodontal disease management}

One small randomised controlled study of antiseptic mouthwash provision along with dental education found no significant differences in preterm $(\mathrm{OR}=1.59,95 \% \mathrm{CI}=0.51-4.92)$ or stillbirth (OR=1.01, 95\% CI $=1.06$ 12.22) [100].

\section{Neonatal interventions}

Tables 7-12 show detailed characteristics of all included studies reporting on neonatal interventions.

\section{Feeding \& nutrition}

There were twenty-two studies of nutritional interventions in small or sick newborns to reduce neonatal mortality [101-123]. Three large-scale randomised controlled trials on preterm neonates found no beneficial impact on neonatal mortality from vitamin A supplementation, a result echoed by a subsequent meta-analysis including these studies [124].

A meta-analysis of three community studies in Ghana, Nepal, and India reported a significant reduction in all-cause neonatal mortality associated with initiation of breastfeeding within 24 hours compared with commencement later than 24 hours ( $\mathrm{OR}=0.56,95 \% \mathrm{CI}=0.40-0.79)$ [109].

\section{Thermal regulation $\&$ homeostasis}

The burden of neonatal hypothermia in babies born in hospital in LMICs has been estimated at 32\%-85\% and is an important contributor to preventable neonatal mortality, with one study reporting an $80 \%$ increase in adjust mortality for every degree Celsius drop in first observed body temperature $[125,126]$. Seven studies reported on thermal regulation [110,127-132]. A recent Cochrane review and meta-analysis of Kangaroo Mother Care (KMC) found in an LMIC subgroup analysis a reduction in all-cause neonatal mortality by $43 \%$ $(\mathrm{OR}=0.57,95 \% \mathrm{CI}=0.37-0.89)$, highlighting the significant potential impact of this low-cost intervention. One study reported a multi-faceted quality improvement project targeted at reducing transitional hypothermia in very low birthweight infants including implementing radiant warmers in the delivery room and specialised transport equipment along with comprehensive staff training. The initial results of this small study of 192 neonates showed a sustained improvement in normothermia (56\% normothermic on arrival to NICU compared with 19\% pre-intervention) and a significant decrease in mortality [128]. 
Table 8. Neonatal interventions- characteristics of individual studies grouped by intervention type (respiratory support)

\begin{tabular}{|c|c|c|c|c|c|c|}
\hline AUTHORS & $\begin{array}{l}\text { YEAR OF } \\
\text { PUBLICATION }\end{array}$ & DATES OF STUDY & LOCATION & STUDY TYPE & STUDY SETTING & POPULATION \\
\hline Ali et al. [150] & 2016 & December 2015. & $\begin{array}{l}\text { LMICs (Iran, } \\
\text { Turkey, China) }\end{array}$ & $\begin{array}{l}\text { Systematic literature } \\
\text { review \& meta-analysis }\end{array}$ & Health facilities & 400 infants. 4 studies \\
\hline Boo et al. [151] & 2016 & $\begin{array}{l}\text { January-December } \\
2013\end{array}$ & Malaysia & Retrospective cohort & $\begin{array}{l}36 \text { neonatal inten- } \\
\text { sive care units in the } \\
\text { Malaysian National } \\
\text { Neonatal Registry }\end{array}$ & $\begin{array}{l}\text { All VLBW neonates born } \\
\text { in participating hospitals } \\
\text { and admitted to NICU } \\
(\mathrm{N}=2823)\end{array}$ \\
\hline Ceylan et al. [162] & 2014 & 2009- 2011 & Turkey & Prospective case/control & $\begin{array}{l}\text { Tertiary referral } \\
\text { centre }\end{array}$ & $\begin{array}{l}\text { Infants with RDS with } \\
\text { GA<33 weeks }(\mathrm{N}=109)\end{array}$ \\
\hline $\begin{array}{l}\text { Crivceanscala et al. } \\
{[167]}\end{array}$ & 2017 & 2013-2016 & Moldova & Prospective cohort & $\begin{array}{l}\text { Tertiary referral } \\
\text { centre }\end{array}$ & $\begin{array}{l}\text { Neonates }<34 \text { weeks GA } \\
\text { with RDS }\end{array}$ \\
\hline Daga et al. [168] & 2014 & June-October 2012 & India & $\begin{array}{l}\text { Pre/post } \\
\text { implementation }\end{array}$ & $\begin{array}{l}\text { Tertiary referral } \\
\text { centre }\end{array}$ & $\begin{array}{l}\text { Neonates admitted to } \\
\text { NICU with RDS during } \\
\text { tiem period }(\mathrm{N}=140, \\
\text { Pre }=56, \text { Post }=84)\end{array}$ \\
\hline Dilmen et al. [169] & 2014 & $\begin{array}{l}\text { June 2009- } \\
\text { June } 2010\end{array}$ & Turkey & RCT & $\begin{array}{l}6 \text { tertiary referral } \\
\text { centres }\end{array}$ & $\begin{array}{l}\text { All infants between } 25 \\
\text { and } 30 \text { weeks GA who } \\
\text { were not intubated in the } \\
\text { delivery room }(\mathrm{N}=159)\end{array}$ \\
\hline $\begin{array}{l}\text { Goncalves-Ferri et } \\
\text { al. [170] }\end{array}$ & 2014 & $\begin{array}{l}\text { June 2008- } \\
\text { December } 2009\end{array}$ & Brazil & RCT & $\begin{array}{l}5 \text { tertiary referral } \\
\text { centres }\end{array}$ & $\begin{array}{l}\text { All neonates with } \\
\text { birthweight } 1000-1500 \mathrm{~g} \\
\text { and no major congenital } \\
\text { malformations who were } \\
\text { not intubated or extubated } \\
<15 \text { min after birth } \\
(\mathrm{N}=197)\end{array}$ \\
\hline $\begin{array}{l}\text { Guinsburg et al. } \\
\text { [164] }\end{array}$ & 2018 & $2014-2015$ & Brazil & Prospective cohort & $\begin{array}{l}20 \text { tertiary referral } \\
\text { centres part of Bra- } \\
\text { zilian Network on } \\
\text { Neonatal Research }\end{array}$ & $\begin{array}{l}\text { Inborn infants ventilated } \\
\text { at birth GA } 23-33 \text { weeks } \\
\text { \& birthweight } 400-1499 \mathrm{~g} \\
(\mathrm{~N}=1962)\end{array}$ \\
\hline Kanmaz et al. [165] & 2013 & $\begin{array}{l}\text { December } 2010- \\
\text { December } 2011\end{array}$ & Turkey & $\mathrm{RCT}$ & $\begin{array}{l}\text { Tertiary referral } \\
\text { centre }\end{array}$ & $\begin{array}{l}\text { Inborn infants } G A<32 \\
\text { weeks with RDS }(\mathrm{N}=200) \text {. } \\
\text { Excluded if required } \\
\text { intubation in delivery } \\
\text { room. }\end{array}$ \\
\hline Kawaza et al. [171] & 2016 & $\begin{array}{l}\text { January-October } \\
2012\end{array}$ & Malawi & $\begin{array}{l}\text { Non-randomized } \\
\text { convenience sample } \\
\text { study }\end{array}$ & $\begin{array}{l}\text { Tertiary referral } \\
\text { hospital }\end{array}$ & $\begin{array}{l}\text { Neonates weighing } \\
>1000 \mathrm{~g} \text { and presenting } \\
\text { with respiratory distress } \\
\text { syndrome ( } \mathrm{N}=87 \text { ( } 62 \\
\text { bCPAP, } 25 \text { controls) } \\
\end{array}$ \\
\hline Kong et al. [172] & 2016 & $2012-2013$ & China & Prospective cohort & $\begin{array}{l}9 \text { NICUs part of } \\
\text { Neonatal Research } \\
\text { Network }\end{array}$ & $\begin{array}{l}\text { Infants GA } 25 \text { weeks to } \\
<28 \text { weeks or infants GA } \\
28 \text { weeks to }<32 \text { weeks } \\
\text { with at least } 3 \text { of } 1 \text { ) } \\
\text { maternal diabetes } 2 \text { ) male } \\
\text { infants 3) multiple births } \\
\text { 4)no/insufficient ACS 5) } \\
\text { emergency intubation } \\
\text { requirement after birth 6) } \\
\text { severe RDS. }(\mathrm{N}=254)\end{array}$ \\
\hline Kumar et al. [173] & 2017 & $\begin{array}{l}\text { June 2014- } \\
\text { June } 2016\end{array}$ & India & $\mathrm{RCT}$ & $\begin{array}{l}\text { Tertiary referral } \\
\text { centre }\end{array}$ & $\begin{array}{l}\text { Preterm neonates } G A<31 \\
\text { weeks who were intubated } \\
\text { immediately postnatally } \\
\text { for RDS and on } \\
\text { mechanical ventilation for } \\
\text { minimum } 24 \mathrm{~h}(\mathrm{~N}=156)\end{array}$ \\
\hline Martin et al. [152] & 2014 & March 2014. & $\begin{array}{l}\text { Malawi, South } \\
\text { Africa }\end{array}$ & $\begin{array}{l}\text { Systematic literature } \\
\text { review \& meta-analysis }\end{array}$ & Health facilities & $\begin{array}{l}582 \text { infants from } 3 \text { studies } \\
\text { used mortality analysis. }\end{array}$ \\
\hline
\end{tabular}


Table 8. continued

\begin{tabular}{|c|c|c|c|c|c|c|}
\hline AUTHORS & $\begin{array}{l}\text { YEAR OF } \\
\text { PUBLICATION }\end{array}$ & DATES OF STUDY & LOCATION & STUDY TYPE & STUDY SETTING & POPULATION \\
\hline Myhre et al. [154] & 2016 & $\begin{array}{l}\text { Pre: November } \\
2007 \text {-April } 2009 . \\
\text { Post: November } \\
\text { 2009-April } 2011 .\end{array}$ & Kenya & $\begin{array}{l}\text { Retrospective pre/post } \\
\text { intervention }\end{array}$ & $\begin{array}{l}\text { Rural district } \\
\text { hospital }\end{array}$ & $\begin{array}{l}\text { All neonates } G A<37 \\
\text { weeks with } \operatorname{RDS}(\mathrm{N}=118 \text {, } \\
\text { Pre }=46 \text {, Post }=72)\end{array}$ \\
\hline $\begin{array}{l}\text { Nahimana et al. } \\
\text { [155] }\end{array}$ & 2015 & $\begin{array}{l}\text { Febrary 2013- } \\
\text { October } 2013\end{array}$ & Rwanda & Retrospective cohort & $\begin{array}{l}\text { Multi-site: } 3 \text { rural } \\
\text { district hospitals }\end{array}$ & $\begin{array}{l}\text { All preterm/very low } \\
\text { birthweight infants } \\
\text { admitted to neonatology } \\
\text { units at study sites } \\
(\mathrm{N}=136 \text { of } 862 \\
\text { admissions) }\end{array}$ \\
\hline Niknafs et al. [156] & 2014 & $\begin{array}{l}\text { June 2012- } \\
\text { December } 2012\end{array}$ & Iran & Prospective cohort & $\begin{array}{l}\text { Multi-site: } 2 \text { tertiary } \\
\text { referral NICUs }\end{array}$ & $\begin{array}{l}\text { Inborn infants suffering } \\
\text { from RDS in either study } \\
\text { site }\end{array}$ \\
\hline $\begin{array}{l}\text { Ntigurirwaet al. } \\
\text { [157] }\end{array}$ & 2017 & Feb 2012-Jan 2014 & Rwanda & $\begin{array}{l}\text { Pre/post } \\
\text { implementation }\end{array}$ & $\begin{array}{l}\text { Multi-site: } 2 \\
\text { university hospitals, } \\
2 \text { district hospitals }\end{array}$ & $\begin{array}{l}\text { Neonates admitted to } \\
\text { neonatal units at study } \\
\text { sites }\end{array}$ \\
\hline Rebello et al. [158] & 2014 & $\begin{array}{l}\text { August 2005- } \\
\text { August } 2007\end{array}$ & Brazil & RCT & $\begin{array}{l}\text { Multi-site - } 19 \\
\text { neonatal intensive } \\
\text { care units }\end{array}$ & $\begin{array}{l}\text { Preterm neonates } \\
\text { born in study centres } \\
\text { with birthweight } 501 \text { - } \\
1500 \mathrm{~g} \text {, age }<25 \text { h of life, } \\
\text { undergoing mechanical } \\
\text { ventilation and with } \\
\text { clinical \& radiological } \\
\text { diagnosis of RDS. } \\
(\mathrm{N}=327)\end{array}$ \\
\hline $\begin{array}{l}\text { Rezzonico et al. } \\
{[167]}\end{array}$ & 2015 & $\begin{array}{l}\text { Pre: May 2006- } \\
\text { December } 2006 . \\
\text { Post: May 2008- } \\
\text { December } 2008 .\end{array}$ & Nicaragua & $\begin{array}{l}\text { Pre/post } \\
\text { implementation }\end{array}$ & $\begin{array}{l}\text { Tertiary referral } \\
\text { centre }\end{array}$ & $\begin{array}{l}\text { Newborns admitted to } \\
\text { NICU "with a history of } \\
\text { ventilatory assistance" } \\
\text { ie, requiring ventilation } \\
\text { resuscitation at birth. } \\
(\mathrm{N}=613 \text {, Pre: } 230 \text {, Post: } \\
383 \text {. }\end{array}$ \\
\hline
\end{tabular}

Mexico, Turkey,

South Africa,

Malaysia, Brazil,

Sankar et al. [159] $2016 \quad$ June 2013.

Chile, Argentina Malaysia, India,

Systematic literature review \& meta-analysis

Health facilities and community

China, Peru,

Uruguay, Iran

\begin{tabular}{llll}
\hline Say et al. [160] & 2016 & $\begin{array}{l}\text { May 2014- } \\
\text { November 2014 }\end{array} \quad$ Turkey \\
\hline & & $\begin{array}{l}\text { Pre: 2010-2012. } \\
\text { Schmidt et al. [139] } 2018\end{array}$ & $\begin{array}{l}\text { Post: October 2013- Lao } \\
\text { July 2016 }\end{array}$
\end{tabular}

Fiji, South Africa,

Thukral et al. [161] $2016 \quad$ December 2014

Malawi, India, Systematic literature Secondary referral Colombia, Nepal, review \& meta-analysis centres Malaysia, India

Retrospective pre/post hospitals with implementation highest mortality rate

Tertiary referral centre

5 provincial

Argentina, Brazil,

Zubizaretta et al. [163]
Chile, Paraguay, Peru, Uruguay
38 studies. 2 RCTs and 22 observational studies reporting on mortality. 
Table 9. Neonatal interventions- characteristics of individual studies grouped by intervention type (cardiovascular support)

\begin{tabular}{|c|c|c|c|c|c|c|}
\hline AUTHORS & $\begin{array}{l}\text { YEAR OF } \\
\text { PUBLICATION }\end{array}$ & DATES OF STUDY & LOCATION & STUDY TYPE & STUDY SETTING & POPULATION \\
\hline Ohlsson et al. [183] & 2018 & November 2017 & $\begin{array}{l}\text { Jordan, Iran, } \\
\text { China, India, } \\
\text { Egypt, Turkey }\end{array}$ & $\begin{array}{l}\text { Systematic literature } \\
\text { review \& meta-analysis }\end{array}$ & Health facilities & $\begin{array}{l}9 \text { studies ( } 8 \text { from LMICs). } \\
272 \text { infants from } 3 \text { studies } \\
\text { all from LMICs included } \\
\text { in mortality meta-analysis. }\end{array}$ \\
\hline Sadeck et al. [182] & 2014 & $\begin{array}{l}\text { January 2010- } \\
\text { December } 2011\end{array}$ & Brazil & Retrospective cohort & $\begin{array}{l}16 \text { tertiary referral } \\
\text { centres part of } \\
\text { Brazilian Network } \\
\text { on Neonatal } \\
\text { Research }\end{array}$ & $\begin{array}{l}\text { Neonates GA<33 weeks, } \\
\text { birthweight } 400-999 g \text {, } \\
\text { echo diagnosis of PDA. } \\
\text { Neonates who died in first } \\
3 \text { d of life were excluded. } \\
(\mathrm{N}=494)\end{array}$ \\
\hline
\end{tabular}

Table 10. Neonatal interventions- characteristics of individual studies grouped by intervention type (Health systems, training and guidelines)

\begin{tabular}{|c|c|c|c|c|c|}
\hline AUTHORS & $\begin{array}{l}\text { YEAR OF } \\
\text { PUBLICATION }\end{array}$ & DATES OF STUDY & LOCATION & STUDY TYPE & STUDY SETTING \\
\hline Ashish et al. [186] & 2016 & $\begin{array}{l}\text { July 2012- } \\
\text { September } 2013\end{array}$ & Nepal & $\begin{array}{l}\text { Pre/post } \\
\text { implementation }\end{array}$ & Tertiary referral centre \\
\hline Bellad et al. [194] & 2016 & $\begin{array}{l}\text { Pre: } \\
\text { November 2011- } \\
\text { October } 2012 \text { Post: } \\
\text { November } 2012- \\
\text { October } 2013\end{array}$ & India and Kenya & $\begin{array}{l}\text { Pre/post } \\
\text { implementation }\end{array}$ & $\begin{array}{l}\text { Multi-site birth cohorts. } \\
\text { Intervention delivered at } \\
\text { facilities that provided } \\
24 / 7 \text { delivery services. } \\
\text { Belgaum: } 19 \text { primary } \\
\text { facilities, } 12 \text { secondary } \\
\text { facilities and } 2 \text { tertiary. } \\
\text { Nagpur: } 2 \text { primary, } 4 \\
\text { secondary, } 9 \text { tertiary. } \\
\text { Kenya: } 18 \text { primary and } \\
5 \text { secondary. }\end{array}$ \\
\hline
\end{tabular}

\section{POPULATION}

All women delivering at $>21$ weeks gestation in the study site $(\mathrm{N}=25108$ deliveries, Pre $=9588$, Post $=15520$ )

All babies born $>1500 \mathrm{~g}$ in all birth cohort study sites. $\mathrm{N}=70704$ (Pre: 35 595, Post: 35 109)

Villages $=$ clusters. $(\mathrm{N}=$ 464). Randomised 1:1. Eligible women: $<50$ y old, married, not sterilised $(\mathrm{N}=29669$, 15532 intervention, 14137 control)

$\begin{array}{llll}\text { Boone et al. [177] } 2017 & \begin{array}{l}\text { August 2008- } \\ \text { November 2011 India }\end{array} \quad \text { RCT (cluster) } & \begin{array}{l}\text { Villages with population } \\ <2500\end{array}\end{array}$

Retrospective pre/post implementation
Tertiary referral centre

All newborns admitted to neonatal unit $(\mathrm{N}=4276$ newborns, Pre $=2118$, Post $=2158$ )

\begin{tabular}{|c|c|c|c|c|c|}
\hline $\begin{array}{l}\text { Cavicchiolo et al. } \\
\text { [197] }\end{array}$ & 2016 & $\begin{array}{l}\text { January 2013- } \\
\text { December } 2014\end{array}$ & Mozambique & $\begin{array}{l}\text { Retrospective } \\
\text { pre/post } \\
\text { implementation }\end{array}$ & Tertiary referral centre \\
\hline
\end{tabular}

\begin{tabular}{|c|c|c|c|c|c|c|}
\hline $\begin{array}{l}\text { Colbourn et al. } \\
\text { [178] }\end{array}$ & 2013 & $\begin{array}{l}\text { October 2008- } \\
\text { December } 2010\end{array}$ & Malawi & RCT (cluster) & $\begin{array}{l}\text { Clusters of approx } \\
4000 \text { people. All } \\
\text { health facilities in } \\
\text { districts included apart } \\
\text { from those providing } \\
\text { CEmOC, those not } \\
\text { providing BEmOC (ie, } \\
\text { dispensaries) and non- } \\
\text { functional facilities. }\end{array}$ & $\begin{array}{l}\text { All pregnant women in } \\
\text { study areas. }\end{array}$ \\
\hline $\begin{array}{l}\text { Dempsey et al. } \\
\text { [184] }\end{array}$ & 2015 & March 2015. & $\begin{array}{l}\text { Argentina, DRC, } \\
\text { Guatemala, India, } \\
\text { Pakistan, Zambia, } \\
\text { Kenya, China }\end{array}$ & $\begin{array}{l}\text { Systematic } \\
\text { literature review \& } \\
\text { meta-analysis }\end{array}$ & Health facilities & $\begin{array}{l}66162 \text { neonates from } 3 \\
\text { studies }\end{array}$ \\
\hline Fottrell et al. [59] & 2013 & $\begin{array}{l}\text { January 2009- } \\
\text { June } 2011\end{array}$ & Bangladesh & RCT (cluster) & 18 unions in 3 districts & $\begin{array}{l}\text { All women residing in } \\
\text { clusters. Accounting for } \\
\mathrm{N}=19301 \text { births during } \\
\text { final } 24 \text { months of } \\
\text { intervention. }\end{array}$ \\
\hline
\end{tabular}


Table 10. continued

\begin{tabular}{|c|c|c|c|c|c|c|}
\hline AUTHORS & $\begin{array}{l}\text { YEAR OF } \\
\text { PUBLICATION }\end{array}$ & DATES OF STUDY & LOCATION & STUDY TYPE & STUDY SETTING & POPULATION \\
\hline Gilbert et al [193] & 2014 & $\begin{array}{l}\text { Pre: July 2008- } \\
\text { June 2009. Post: } \\
\text { October 2009- } \\
\text { September } 2010 .\end{array}$ & Brazil & $\begin{array}{l}\text { Prospective } \\
\text { Pre/post } \\
\text { implementation }\end{array}$ & 5 tertiary referral centres & $\begin{array}{l}\text { Infants with } B W<1501 g \\
\text { or } G A<35 \text { weeks } \\
\text { admitted to study NICUs } \\
(\mathrm{N}=1242 \text {, Pre: } 679 \text {, Post: } \\
563) \text {. }\end{array}$ \\
\hline Gomez et al. [86] & 2018 & $\begin{array}{l}\text { March } 2014- \\
\text { February } 2017 . \\
\text { Each facility } \\
\text { enrolled for } 18 \mathrm{mo} . \\
\text { Data collected } 6 \mathrm{mo} \\
\text { preintervention } \\
\text { and } 12 \text { mo } \\
\text { postintervention. }\end{array}$ & Ghana & $\begin{array}{l}\text { Cluster randomized } \\
\text { trial (sites } \\
\text { randomised to } 1 \text { of } \\
4 \text { implementation } \\
\text { waves) }\end{array}$ & $\begin{array}{l}40 \text { public \& mission } \\
\text { hospitals - } 3 \text { regional } \\
\text { hospitals, } 38 \text { district } \\
\text { hospitals and } 1 \\
\text { polyclinic }\end{array}$ & $\begin{array}{l}\text { All newborns delivered } \\
\text { at particpating facilities } \\
(\mathrm{N}=105850 \text {. Pre: } 38192 \text {, } \\
\text { Post months 1-6: } 36160 \text {, } \\
\text { Post months } 7-12 \text { : } \\
31498)\end{array}$ \\
\hline Harris et al. [198] & 2018 & $\begin{array}{l}\text { Unclear on dates. } \\
\text { NMR audited } 3 \text { mo } \\
\text { pre-intervention } \\
\text { and then } 3 \text { mo post } \\
\text { implementation } \\
\text { and for } 3 \text { mo at the } \\
\text { same time of year } \\
3 \text { y and } 6 \text { y post } \\
\text { implementation. }\end{array}$ & Uganda & $\begin{array}{l}\text { Pre/post } \\
\text { implementation }\end{array}$ & District mission hospital & $\begin{array}{l}\text { All newborns admitted to } \\
\text { neonatal unit }\end{array}$ \\
\hline $\begin{array}{l}\text { Hosseini et al. } \\
{[144]}\end{array}$ & 2017 & $\begin{array}{l}\text { January 2013- } \\
\text { June } 2015\end{array}$ & Iran & $\mathrm{RCT}$ & Tertiary referral centre & $\begin{array}{l}\text { Preterm infants with } \\
\text { birthweight }<1500 \mathrm{~g} \\
\text { admitted to NICU with } \\
\text { suspected sepsis }(\mathrm{N}=209)\end{array}$ \\
\hline Kakkad et al. [199] & 2014 & $\begin{array}{l}\text { Pre: Sept 2011-Aug } \\
\text { 2012. Post: Sept } \\
\text { 2012-Aug 2013. }\end{array}$ & India & $\begin{array}{l}\text { Retrospective pre/ } \\
\text { post intervention }\end{array}$ & Tertiary referral centre & $\begin{array}{l}\text { All neonates admitted } \\
\text { to NICU }(\mathrm{N}=7568, \\
\text { Pre }=3455, \text { Post }=4133)\end{array}$ \\
\hline $\begin{array}{l}\text { Kirkwood et al. } \\
\text { [181] }\end{array}$ & 2013 & $\begin{array}{l}\text { November 2008- } \\
\text { December } 2009\end{array}$ & Ghana & RCT (cluster) & $\begin{array}{l}7 \text { rural districts split } \\
\text { into } 98 \text { clusters based } \\
\text { on community-based } \\
\text { surveillance volunteer } \\
\text { (CBSV) supervisory } \\
\text { zones }\end{array}$ & $\begin{array}{l}\text { All pregnancies that } \\
\text { ended in a livebirth or } \\
\text { stillbirth in study areas } \\
\text { (N=18609 eligible } \\
\text { pregnancies). }\end{array}$ \\
\hline Leng et al. [128] & 2016 & $\begin{array}{l}\text { Pre: January 2010- } \\
\text { March 2011. Post: } \\
\text { October 2012- } \\
\text { September } 2013 \text {. }\end{array}$ & China & $\begin{array}{l}\text { Ambispective } \\
\text { cohort }\end{array}$ & Tertiary referral centre & $\begin{array}{l}\text { Outborn VLBW neonates } \\
\text { referred to study NICU } \\
\text { within } 12 \text { h of birth (pre: } \\
86 \text {, post: } 86 \text { ) }\end{array}$ \\
\hline Lewcyka et al. [63] & 2013 & $\begin{array}{l}\text { December 2004- } \\
\text { December } 2010\end{array}$ & Malawi & RCT (cluster) & 48 community clusters & $\begin{array}{l}48 \text { equal-sized clusters } \\
\text { of approx. } 3000 \text { people } \\
\text { randomly allocated to } 1 \text { of } \\
4 \text { groups. All women aged } \\
10-49 \text { included: (total } \\
\mathrm{N}=55931 \text { ). Outcomes } \\
\text { monitored for } \mathrm{N}=26262 \\
\text { births. }\end{array}$ \\
\hline
\end{tabular}


Table 10. continued

\begin{tabular}{|c|c|c|c|c|c|c|}
\hline AUTHORS & $\begin{array}{l}\text { YEAR OF } \\
\text { PUBLICATION }\end{array}$ & DATES OF STUDY & LOCATION & STUDY TYPE & STUDY SETTING & POPULATION \\
\hline Li et al. [135] & 2015 & $\begin{array}{l}\text { January 2008- } \\
\text { December } 2013 \\
\text { (Retrospective: } \\
\text { Jan 2008-Dec 2010, } \\
\text { Prospective } \\
\text { Jan 2011-Dec 2013) }\end{array}$ & China & $\begin{array}{l}\text { Ambispective } \\
\text { cohort }\end{array}$ & Tertiary referral centre & $\begin{array}{l}\text { All newborns admitted to } \\
\text { neonatology department } \\
\text { with TTN and GA } \\
\text { between } 34 \text { and } 42 \text { weeks } \\
(\mathrm{N}=1485) \text {. Excluded if } \\
\text { BW<2000g. }\end{array}$ \\
\hline $\begin{array}{l}\text { Massawe et al. } \\
\text { [130] }\end{array}$ & 2018 & $\begin{array}{l}\text { Pre: Sept 2014- } \\
\text { May 2015, } \\
\text { Post: June 2015- } \\
\text { June } 2017\end{array}$ & Tanzania & $\begin{array}{l}\text { Pre/post } \\
\text { implementation }\end{array}$ & $\begin{array}{l}\text { Multi-site: } 3 \text { tertiary } \\
\text { referral hospitals, } 1 \\
\text { district hospital }\end{array}$ & $\begin{array}{l}\text { Inpatient pregnant wo- } \\
\text { men and inborn preterm } \\
\text { neonates. } \mathrm{N}=3496 \\
\text { preterm babies ( } 543 \text { pre- } \\
\text { implementation, } 2953 \\
\text { post-implementation). }\end{array}$ \\
\hline Mduma et al. [187] & 2015 & $\begin{array}{l}\text { Pre: February 2010- } \\
\text { January } 2011 . \\
\text { Post: February } \\
2011 \text { - January } 2012\end{array}$ & Tanzania & $\begin{array}{l}\text { Pre/post } \\
\text { implementation }\end{array}$ & Rural referral hospital & $\begin{array}{l}\text { All deliveries at study site } \\
(\mathrm{N}=9708 \text {, Pre }-\mathrm{N}=4894 \text {, } \\
\text { Post- } \mathrm{N}=4814)\end{array}$ \\
\hline Msemo et al. [196] & 2013 & $\begin{array}{l}\text { Pre: July 2009- } \\
\text { August } 2009 \text {, } \\
\text { Post: Sept } 2009 \text { - } \\
\text { March } 2012\end{array}$ & Tanzania & $\begin{array}{l}\text { Pre/post } \\
\text { implementation }\end{array}$ & $\begin{array}{l}\text { Multi-site: } 3 \text { tertiary } \\
\text { referral hospitals, } 4 \\
\text { associated regional } \\
\text { hospitals, } 1 \text { district } \\
\text { hospital }\end{array}$ & $\begin{array}{l}\text { Newborns with a } \\
5 \text {-min Apgar score }<7 \\
\text { and requirement for } \\
\text { facemask ventilation with } \\
\text { BW }>750 \mathrm{~g} \text { or } \mathrm{SB}>1000 \mathrm{~g} \\
(\mathrm{~N}=85338,7969 \text { pre, } \\
77369 \text { post })\end{array}$ \\
\hline $\begin{array}{l}\text { Namazzi et al. } \\
\text { [188] }\end{array}$ & 2015 & $\begin{array}{l}\text { 2007-2011 (pre: } \\
\text { 2007-2009, post: } \\
\text { 2009-2011) }\end{array}$ & Uganda & $\begin{array}{l}\text { Pre/post } \\
\text { implementation }\end{array}$ & $\begin{array}{l}\text { Demographic \& health } \\
\text { surveillance Site. } 20 \\
\text { health facilities targeted: } \\
1 \text { district hospital, } 1 \text { level } \\
\text { IV health centre, } 6 \text { level } \\
\text { III health centres and } 12 \\
\text { level II health centres }\end{array}$ & $\begin{array}{l}\text { Health facilities within } \\
\text { district serving a } \\
\text { population of around } \\
70000\end{array}$ \\
\hline $\begin{array}{l}\text { Ntigurirwa et al. } \\
\text { [157] }\end{array}$ & 2017 & Feb 2012-Jan 2014 & Rwanda & $\begin{array}{l}\text { Pre/post } \\
\text { implementation }\end{array}$ & $\begin{array}{l}\text { Multi-site: } 2 \text { university } \\
\text { hospitals, } 2 \text { district } \\
\text { hospitals }\end{array}$ & $\begin{array}{l}\text { Neonates admitted to } \\
\text { neonatal units at study } \\
\text { sites }\end{array}$ \\
\hline Opiyo et al. [189] & 2015 & February 2015. & Kenya, Sri Lanka & $\begin{array}{l}\text { Systematic } \\
\text { literature review } \& \\
\text { meta-analysis }\end{array}$ & Primary health facilities & 2 studies \\
\hline Pammi et al. [195] & 2016 & April 2015. & $\begin{array}{l}\text { Argentina, DRC, } \\
\text { Guatemala, India, } \\
\text { Pakistan, Zambia, } \\
\text { China, Kenya }\end{array}$ & $\begin{array}{l}\text { Systematic } \\
\text { literature review } \& \\
\text { meta-analysis }\end{array}$ & $\begin{array}{l}\text { Health facilities and } \\
\text { community }\end{array}$ & $\begin{array}{l}14 \text { studies. } 28923 \text { infants } \\
\text { from } 3 \text { studies included } \\
\text { in meta-analysis. }\end{array}$ \\
\hline Patel et al. [104] & 2018 & $\begin{array}{l}\text { Pre: December } \\
\text { 2013-October } 2014 . \\
\text { Post: November } \\
\text { 2014-December } \\
2015 .\end{array}$ & India & $\begin{array}{l}\text { Retrospective } \\
\text { pre/post } \\
\text { implementation }\end{array}$ & Tertiary referral centre & $\begin{array}{l}\text { Preterm infants }<35 \\
\text { weeks GA admitted to } \\
\text { neonatal unit }(\mathrm{N}=199 \text {, } \\
\text { Pre: } 145 \text {, Post: } 44)\end{array}$ \\
\hline Pinto et al. [145] & 2013 & $\begin{array}{l}\text { Pre: January } 2006- \\
\text { December } 2007 . \\
\text { Post: January } 2008- \\
\text { December } 2008 .\end{array}$ & Brazil & $\begin{array}{l}\text { Pre/post } \\
\text { implementation }\end{array}$ & Tertiary referral centre & $\begin{array}{l}\text { Newborns }<1500 \mathrm{~g} \\
\text { admitted to NICU and } \\
\text { commenced on broad- } \\
\text { spectrum Abx for } \\
\text { suspected sepsis }(\mathrm{N}=136 \text {, } \\
\text { Pre: } 91 \text {, Post: } 45) \text {. }\end{array}$ \\
\hline Schmidt et al. [139] & 2018 & $\begin{array}{l}\text { Pre: } 2010-2012 . \\
\text { Post: October } 2013- \\
\text { July } 2016\end{array}$ & Lao & $\begin{array}{l}\text { Retrospective } \\
\text { pre/post } \\
\text { implementation }\end{array}$ & $\begin{array}{l}5 \text { provincial hospitals } \\
\text { with highest mortality } \\
\text { rate }\end{array}$ & $\begin{array}{l}\text { Newborns admitted to } \\
\text { pediatric ward or NICU } \\
\text { in participating sites. } \\
(\mathrm{N}=3889 \text {, Pre } \mathrm{N}=1673 \\
\text { Post } \mathrm{N}=2216) \text {. }\end{array}$ \\
\hline Singh et al. [180] & 2013 & $\begin{array}{l}\text { April 2008- } \\
\text { December } 2009\end{array}$ & Ghana & $\begin{array}{l}\text { Interrupted time- } \\
\text { series }\end{array}$ & $\begin{array}{l}\text { Facilities in } 4 \text { rural dis- } \\
\text { tricts - } 25 \text { health centres } \\
\text { and } 2 \text { district hospitals }\end{array}$ & $\begin{array}{l}\text { Women and children } \\
\text { receiving care at these } \\
\text { facilities (inclusion/ } \\
\text { exclusion unclear) }\end{array}$ \\
\hline
\end{tabular}


Table 10. continued

\begin{tabular}{|c|c|c|c|c|c|c|}
\hline AUTHORS & $\begin{array}{l}\text { YEAR OF } \\
\text { PUBLICATION }\end{array}$ & DATES OF STUDY & LOCATION & STUDY TYPE & STUDY SETTING & POPULATION \\
\hline Soofi et al. [141] & 2017 & $\begin{array}{l}\text { April 2009- } \\
\text { December } 2012\end{array}$ & Pakistan & RCT (cluster) & $\begin{array}{l}\text { Rural district with } \\
\text { population approx. } 0.56 \\
\text { million. Clustered into } \\
27 \text { clusters served by } \\
\text { an individual functional } \\
\text { primary care facility. }\end{array}$ & $\begin{array}{l}\text { All households in study } \\
\text { area }\end{array}$ \\
\hline Sousa et al. [190] & 2015 & Not reported & $\begin{array}{l}\text { Guatemala, DRC, } \\
\text { Pakistan, Zambia, } \\
\text { India, Uganda, } \\
\text { Kenya, Pakistan, } \\
\text { Tanzania, Malawi, } \\
\text { Bangladesh }\end{array}$ & $\begin{array}{l}\text { Systematic } \\
\text { literature review } \& \\
\text { meta-analysis }\end{array}$ & $\begin{array}{l}\text { Health facilities and } \\
\text { community }\end{array}$ & 14 studies. \\
\hline Turner et al. [191] & 2013 & $\begin{array}{l}\text { January 2008- } \\
\text { December } 2011\end{array}$ & $\begin{array}{l}\text { Thai/Myanmar } \\
\text { border }\end{array}$ & $\begin{array}{l}\text { Retrospective } \\
\text { cohort }\end{array}$ & NICU in refugee camp & $\begin{array}{l}\text { All newborns admitted } \\
\text { to special care baby unit } \\
\text { GA }>27 \text { weeks whose } \\
\text { mother had ANC In } \\
\text { refugee camp }(\mathrm{N}=923) \text {. }\end{array}$ \\
\hline $\begin{array}{l}\text { Wrammert et al. } \\
\text { [192] }\end{array}$ & 2017 & $\begin{array}{l}\text { July } 2012- \\
\text { September } 2013\end{array}$ & Nepal & $\begin{array}{l}\text { Prospective } \\
\text { pre/post } \\
\text { implementation }\end{array}$ & Tertiary referral centre & $\begin{array}{l}\text { All women delivering at } \\
>21 \text { weeks gestation in } \\
\text { the study site }(N=24665 \\
\text { deliveries, Pre }=9390, \\
\text { Post }=15275) \text {. }\end{array}$ \\
\hline Zhou et al. [142] & 2013 & $\begin{array}{l}\text { Pre: February } \\
\text { 2006-January } \\
\text { 2007. Partial } \\
\text { intervention: August } \\
\text { 2008-July 2009. } \\
\text { Full intervention: } \\
\text { January 2010- } \\
\text { December } 2010\end{array}$ & China & $\begin{array}{l}\text { Pre/post } \\
\text { implementation }\end{array}$ & Tertiary referral centre & $\begin{array}{l}\text { All neonates who received } \\
\text { mechanical ventilation } \\
\text { for at least } 48 \text { h and were } \\
\text { hospitalized in NICU for } \\
\text { at least } 5 \mathrm{~d}(\mathrm{~N}=491 \text {, Pre: } \\
\text { 106, Partial: } 169 \text {, Full: } \\
\text { 216) }\end{array}$ \\
\hline $\begin{array}{l}\text { Zonneveld et al. } \\
\text { [200] }\end{array}$ & 2017 & $\begin{array}{l}\text { Pre: July 2014- } \\
\text { March 2015. Post: } \\
\text { March 2015- } \\
\text { December } 2015\end{array}$ & Suriname & $\begin{array}{l}\text { Retrospective } \\
\text { pre/post } \\
\text { implementation. }\end{array}$ & Tertiary referral centre & $\begin{array}{l}\text { All inborn \& outborn } \\
\text { neonates admitted to } \\
\text { study site }(\mathrm{N}=601, \text { Pre: } \\
\text { 320, Post: } 281)\end{array}$ \\
\hline
\end{tabular}

Table 11. Neonatal interventions- characteristics of individual studies grouped by intervention type (feeding and nutrition)

\begin{tabular}{|c|c|c|c|c|c|c|}
\hline AUTHORS & $\begin{array}{l}\text { YEAR OF } \\
\text { PUBLICATION }\end{array}$ & DATES OF STUDY & LOCATION & STUDY TYPE & STUDY SETTING & POPULATION \\
\hline $\begin{array}{l}\text { Banupriya et al. } \\
\text { [112] }\end{array}$ & 2017 & $\begin{array}{l}\text { May 2013- } \\
\text { November } 2015\end{array}$ & India & RCT & $\begin{array}{l}\text { Tertiary referral } \\
\text { centre }\end{array}$ & $\begin{array}{l}\text { Neonates aged }<28 \mathrm{~d} \text {, } \\
\text { GA }>31 \text { weeks, on significant } \\
\text { enteral feeds, biochemical or } \\
\text { microbioogical evidence of } \\
\text { infection }(\mathrm{N}=134) \text {. Excluded if } \\
\text { already on } \mathrm{Abx} \text { for sepsis. }\end{array}$ \\
\hline Debes et al. [109] & 2013 & December 2011 & $\begin{array}{l}\text { Ghana, Nepal, } \\
\text { India }\end{array}$ & $\begin{array}{l}\text { Systematic } \\
\text { literature review } \& \\
\text { meta-analysis }\end{array}$ & $\begin{array}{l}\text { Health facilities and } \\
\text { community }\end{array}$ & $\begin{array}{l}18 \text { studies. } 3 \text { studies included } \\
\text { in mortality analyses. }\end{array}$ \\
\hline $\begin{array}{l}\text { Deshpande et al. } \\
\text { [102] }\end{array}$ & 2017 & January 2017 & $\begin{array}{l}\text { Egypt, Brazil, } \\
\text { Iran, Turkey, } \\
\text { China, Mexico, } \\
\text { India, Colombia, } \\
\text { Thailand, South } \\
\text { Africa }\end{array}$ & $\begin{array}{l}\text { Systematic } \\
\text { literature review \& } \\
\text { meta-analysis }\end{array}$ & $\begin{array}{l}\text { Health facilities and } \\
\text { community }\end{array}$ & 4783 infants. 23 studies. \\
\hline Dilli et al. [114] & 2015 & $\begin{array}{l}\text { June } 2011 \text { - } \\
\text { June } 2014\end{array}$ & Turkey & RCT & $\begin{array}{l}5 \text { tertiary referral } \\
\text { centres }\end{array}$ & $\begin{array}{l}\text { VLBW infants with } G A<32 \\
\text { weeks and birthweight }<1500 \mathrm{~g} \\
(\mathrm{~N}=400) \text {. Neonates who } \\
\text { died in 1st week of life were } \\
\text { excluded. }\end{array}$ \\
\hline
\end{tabular}


Table 11. continued

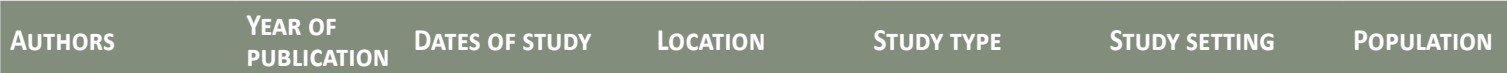

Edmond et al

[101]

2015

August 2010-

November 2011

Ghana

RCT

7 rural districts

Newborns identified at home or facilities on day of birth or in the next $2 \mathrm{~d}$, more than $2 \mathrm{~h}$ old and able to feed orally. $(\mathrm{N}=22955)$

\begin{tabular}{lcllll}
\hline English et al. [110] & 2017 & January 2014 & LMICs & $\begin{array}{l}\text { Review of } \\
\text { systematic reviews }\end{array}$ & $\begin{array}{l}\text { Health facilities } \\
\text { community }\end{array}$ \\
\hline $\begin{array}{l}\text { Fernandez-Carro- } \\
\text { cera et al [116] }\end{array}$ & 2013 & $\begin{array}{l}\text { January 2007- } \\
\text { June 2010 }\end{array}$ & Mexico & RCT & $\begin{array}{l}\text { Tertiary referral } \\
\text { centre }\end{array}$ \\
\hline $\begin{array}{l}\text { Guney-Varal et al. } \\
\text { [113] }\end{array}$ & 2017 & $\begin{array}{l}\text { "one year period"- } \\
\text { dates not reported }\end{array}$ & Turkey & RCT & $\begin{array}{l}\text { Tertiary referral } \\
\text { centre }\end{array}$ \\
\hline & & & India & RCT & $\begin{array}{l}\text { Tertiary referral } \\
\text { centre }\end{array}$
\end{tabular}
Bangladesh, Philippines, India, Systematic Ghana, Mexico, Nepal, Brazil

Khan et al. [11] $2015 \quad$ Not reported

\begin{tabular}{|c|c|c|c|c|c|}
\hline Lund et al. [118] & 2014 & $\begin{array}{l}\text { February 2008- } \\
\text { November } 2008 \\
\text { (stopped early) }\end{array}$ & Guinea-Bissau & RCT & $\begin{array}{l}\text { All districts of } \\
\text { capital city }\end{array}$ \\
\hline $\begin{array}{l}\text { Mahallei et al. } \\
\text { [119] }\end{array}$ & 2016 & Not reported & Iran & RCT & $\begin{array}{l}\text { Tertiary referral } \\
\text { centre }\end{array}$ \\
\hline
\end{tabular}

$\begin{array}{llll}\text { Masanja et al. [120] } 2015 & \begin{array}{l}\text { August 2010- } \\ \text { March 2013 }\end{array} \text { Tanzania } & \text { RCT }\end{array}$

$\begin{array}{llll} & & & \\ & & & \\ \text { Mazumder et al. } & 2015 & \text { June 2010- July districts (approx. } \\ {[121]} & 2012 & \text { India } & \text { RCT }\end{array}$

\begin{tabular}{|c|c|c|c|c|c|}
\hline $\begin{array}{l}\text { Nandhini et al. } \\
\text { [122] }\end{array}$ & 2016 & Not reported & India & RCT & $\begin{array}{l}\text { Tertiary referral } \\
\text { centre }\end{array}$ \\
\hline
\end{tabular}

\begin{tabular}{|c|c|c|c|c|c|c|}
\hline Oncel et al. [115] & 2014 & $\begin{array}{l}\text { February 2012- } \\
\text { February } 2013\end{array}$ & Turkey & RCT & $\begin{array}{l}\text { Tertiary referral } \\
\text { centre }\end{array}$ & $\begin{array}{l}\text { Preterm infants } G A<33 \text { weeks } \\
\text { and birthweight }<1501 \mathrm{~g} \text { who } \\
\text { survived to feed enterally } \\
(\mathrm{N}=400)\end{array}$ \\
\hline $\begin{array}{l}\text { Panigrahi et al. } \\
\text { [103] }\end{array}$ & 2017 & Not reported & India & RCT & $\begin{array}{l}149 \text { randomly } \\
\text { chosen villages in } \\
1 \text { state }\end{array}$ & $\begin{array}{l}\text { All births identified in study } \\
\text { villages }(\mathrm{N}=4556) \text {. Excluded } \\
\text { neonates }<35 \text { weeks gestation } \\
\text { or }<2000 \mathrm{~g} \text { birthweight. }\end{array}$ \\
\hline Patel et al. [104] & 2018 & $\begin{array}{l}\text { Pre: December } \\
\text { 2013-October } \\
\text { 2014. Post: } \\
\text { November 2014- } \\
\text { December } 2015\end{array}$ & India & $\begin{array}{l}\text { Retrospective } \\
\text { pre/post } \\
\text { implementation }\end{array}$ & $\begin{array}{l}\text { Tertiary referral } \\
\text { centre }\end{array}$ & $\begin{array}{l}\text { Preterm infants }<35 \text { weeks } \\
\text { GA admitted to neonatal unit } \\
(\mathrm{N}=199, \text { Pre: } 145, \text { Post: } 44)\end{array}$ \\
\hline
\end{tabular}

All newborn males weighing $<2.5 \mathrm{~kg}$ at discharge from maternity ward of the national hospital ( $\mathrm{N}=232$ at point trial stopped)

Preterm neonates $G A<32$ weeks \& birthweight $<1500 \mathrm{~g}$ $(\mathrm{N}=120)$

Dar Es Salaam - mothers/ newborns from 1 antenatal clinics/labour wards. Morogoro region - nested within health and demographic surveillance system. Newborns eligible if able to feed orally (same criteria as other Neovit studies) $(\mathrm{N}=31999)$

Pregnant women identified through 3 moly surveillance programme. All neonates who were able to feed orally were eligible $(\mathrm{N}=44,984)$.

Enterally fed preterm neonates GA 28 - 34 weeks and $>1000 \mathrm{~g}$ and birthweight $<1501 \mathrm{~g}$ who All births identified in study Inborn neonates $<2000 \mathrm{~g}$ admitted to NICU in first $12 \mathrm{~h}$ of birth with no maternal risk Neonates who developed culture-proven sepsis within $72 \mathrm{~h}$ of life were excluded.

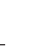


Table 11. continued

\begin{tabular}{|c|c|c|c|c|c|c|}
\hline AUTHORS & $\begin{array}{l}\text { YEAR OF } \\
\text { PUBLICATION }\end{array}$ & DATES OF STUDY & LOCATION & STUDY TYPE & STUDY SETTING & POPULATION \\
\hline Santana et al. [105] & 2017 & $\begin{array}{l}\text { August 2014- } \\
\text { October } 2015\end{array}$ & Brazil & $\begin{array}{l}\text { Retrospective } \\
\text { cohort }\end{array}$ & $\begin{array}{l}\text { Tertiary referral } \\
\text { centre }\end{array}$ & $\begin{array}{l}\text { All consecutive neoantes } \\
\text { GA<37 weeks born at study } \\
\text { site and admitted for at least } 5 \\
\text { d to NICU }(\mathrm{N}=300) \text {. Neonates } \\
\text { with "trans-placental infection } \\
\text { potential" excluded. }\end{array}$ \\
\hline Serce et al. [106] & 2013 & $\begin{array}{l}\text { October 2012- } \\
\text { November } 2011\end{array}$ & Turkey & RCT & $\begin{array}{l}\text { Tertiary referral } \\
\text { centre }\end{array}$ & $\begin{array}{l}\text { Preterm newborns admitted } \\
\text { to NICU }(\mathrm{GA}<33 \text { weeks, } \\
\text { birthweight }<1501 \mathrm{~g}) \text {. } \\
\text { Excluded if death occurred in } \\
\text { first } 24 \mathrm{~h}(\mathrm{~N}=208)\end{array}$ \\
\hline Tali et al. [108] & 2016 & Not reported & India & $\mathrm{RCT}$ & $\begin{array}{l}\text { Tertiary referral } \\
\text { centre }\end{array}$ & $\begin{array}{l}\text { Neonates admitted to NICU } \\
\text { weighing } 501-1500 \text { g. Exclu- } \\
\text { ded if GI or other severe } \\
\text { congenital malformations, or } \\
\text { if severely unwell such that } \\
\text { not able to feed (severe sepsis, } \\
\text { shock etc) }(\mathrm{N}=120) \text {. }\end{array}$ \\
\hline $\begin{array}{l}\text { Van Niekerk et al. } \\
\text { [123] }\end{array}$ & 2015 & $\begin{array}{l}\text { July 2011- } \\
\text { August } 2012\end{array}$ & South Africa & RCT & $\begin{array}{l}\text { Tertiary referral } \\
\text { centre }\end{array}$ & $\begin{array}{l}\text { HIV-exposed and HIV-unex- } \\
\text { posed infants }<34 \text { weeks GA } \\
\text { anc }<1250 \mathrm{~g} \text { who were breast- } \\
\text { milk fed delivered in study site }\end{array}$ \\
\hline
\end{tabular}

Table 12. Neonatal interventions- characteristics of individual studies grouped by intervention type (community mobilisation)

\begin{tabular}{|c|c|c|c|c|c|c|}
\hline AUTHORS & $\begin{array}{l}\text { YEAR OF } \\
\text { PUBLICATION }\end{array}$ & DATES OF STUDY & LOCATION & STUDY TYPE & STUDY SETTING & POPULATION \\
\hline Boone et al. [177] & 2017 & $\begin{array}{l}\text { August 2008- } \\
\text { November } 2011\end{array}$ & India & RCT (cluster) & $\begin{array}{l}\text { Villages with populations } \\
<2500\end{array}$ & $\begin{array}{l}\text { Villages }=\text { clusters. } \\
(\mathrm{N}=464) \text {. Randomised } \\
\text { 1:1. Eligible women: } \\
<50 \text { y old, married, not } \\
\text { sterilised ( } \mathrm{N}=29669 \text {, } \\
15532 \text { intervention, } \\
14137 \text { control) }\end{array}$ \\
\hline
\end{tabular}

\begin{tabular}{|c|c|c|c|c|c|c|}
\hline $\begin{array}{l}\text { Colbourn et al. } \\
\text { [178] }\end{array}$ & 2013 & $\begin{array}{l}\text { October 2008- } \\
\text { December } 2010\end{array}$ & Malawi & RCT (cluster) & $\begin{array}{l}\text { Clusters of approx } \\
4000 \text { people. All } \\
\text { health facilities in dis- } \\
\text { tricts included apart } \\
\text { from those providing } \\
\text { CEmOC, those not } \\
\text { providing BEmOC (ie, } \\
\text { dispensaries) and non- } \\
\text { functional facilities. }\end{array}$ & $\begin{array}{l}\text { All pregnant women in } \\
\text { study areas. }\end{array}$ \\
\hline Fottrell et al. [59] & 2013 & $\begin{array}{l}\text { January 2009- } \\
\text { June } 2011\end{array}$ & Bangladesh & RCT (cluster) & 18 unions in 3 districts & $\begin{array}{l}\text { All women residing in } \\
\text { clusters. Accounting } \\
\text { for } \mathrm{N}=19301 \text { births } \\
\text { during final } 24 \text { mo of } \\
\text { intervention. }\end{array}$ \\
\hline $\begin{array}{l}\text { Kirkwood et al. } \\
\text { [181] }\end{array}$ & 2013 & $\begin{array}{l}\text { November } 2008- \\
\text { December } 2009\end{array}$ & Ghana & RCT (cluster) & $\begin{array}{l}7 \text { rural districts split } \\
\text { into } 98 \text { clusters based } \\
\text { on community-based } \\
\text { surveillance volunteer } \\
\text { (CBSV) supervisory } \\
\text { zones }\end{array}$ & $\begin{array}{l}\text { All pregnancies that } \\
\text { ended in a livebirth or } \\
\text { stillbirth in study areas } \\
\text { ( } \mathrm{N}=18609 \text { eligible } \\
\text { pregnancies). }\end{array}$ \\
\hline Lassi et al. [64] & 2015 & May 2014 & LMICs & $\begin{array}{l}\text { Systematic } \\
\text { literature review \& } \\
\text { meta-analysis }\end{array}$ & Community & $\begin{array}{l}26 \text { studies. } 302646 \text { in- } \\
\text { fants from } 21 \text { studies used } \\
\text { in NMR meta-analysis }\end{array}$ \\
\hline
\end{tabular}


Table 12. continued

\begin{tabular}{|c|c|c|c|c|c|c|}
\hline AUTHORS & $\begin{array}{l}\text { YEAR OF } \\
\text { PUBLICATION }\end{array}$ & DATES OF STUDY & LOCATION & STUDY TYPE & STUDY SETTING & POPULATION \\
\hline Lassi et al. [176] & 2016 & January 2015 & LMICs & $\begin{array}{l}\text { Systematic } \\
\text { literature review } \& \\
\text { meta-analysis }\end{array}$ & Community & $\begin{array}{l}310652 \text { participants. } \\
58 \text { studies. } 20 \text { studies } \\
(\mathrm{N}=248848) \text { included in } \\
\text { mortality analyses. }\end{array}$ \\
\hline Lewcyka et al. [63] & 2013 & $\begin{array}{l}\text { December } 2004- \\
\text { December } 2010\end{array}$ & Malawi & RCT (cluster) & 48 community clusters & $\begin{array}{l}48 \text { equal-sized clusters } \\
\text { of approx. } 3000 \text { people } \\
\text { randomly allocated to } 1 \text { of } \\
4 \text { groups. All women aged } \\
10-49 \text { included: (total } \\
\mathrm{N}=55931 \text { ). Outcomes } \\
\text { monitored for } \mathrm{N}=26262 \\
\text { births. }\end{array}$ \\
\hline Persson et al. [179] & 2013 & $\begin{array}{l}\text { July 2008- } \\
\text { June } 2011\end{array}$ & Vietnam & RCT (cluster) & $\begin{array}{l}90 \text { of } 187 \text { communes } \\
\text { in } 1 \text { province }\end{array}$ & $\begin{array}{l}\text { All women and children } \\
\text { in participating commu- } \\
\text { nes. } \mathrm{N}=22561 \text { births } \\
\text { registered during study } \\
\text { period. }\end{array}$ \\
\hline $\begin{array}{l}\text { Sarbani Roy et al. } \\
\text { [131] }\end{array}$ & 2013 & $\begin{array}{l}\text { November 2004- } \\
\text { July } 2011\end{array}$ & India & Prospective cohort & $\begin{array}{l}\text { India: } 2 \text { states, } \\
\text { community DHS data }\end{array}$ & $\begin{array}{l}\text { All births, stillbirths and } \\
\text { neonatal deaths in } 36 \\
\text { geographical clusters } \\
\text { recorded via surveillance } \\
\text { system }\end{array}$ \\
\hline Singh et al. [180] & 2013 & $\begin{array}{l}\text { April 2008- } \\
\text { December } 2009\end{array}$ & Ghana & $\begin{array}{l}\text { Interrupted time- } \\
\text { series }\end{array}$ & $\begin{array}{l}\text { Facilities in } 4 \text { rural dis- } \\
\text { tricts - } 25 \text { health centres } \\
\text { and } 2 \text { district hospitals }\end{array}$ & $\begin{array}{l}\text { Women and children } \\
\text { receiving care at these } \\
\text { facilities (inclusion/ } \\
\text { exclusion unclear) }\end{array}$ \\
\hline Soofi et al. [141] & 2017 & $\begin{array}{l}\text { April 2009- } \\
\text { December } 2012\end{array}$ & Pakistan & RCT (cluster) & $\begin{array}{l}\text { Rural district with popu- } \\
\text { lation approx. } 0.56 \\
\text { million. Clustered into } \\
27 \text { clusters served by } \\
\text { an individual functional } \\
\text { primary care facility. }\end{array}$ & $\begin{array}{l}\text { All households in study } \\
\text { area }\end{array}$ \\
\hline
\end{tabular}

\section{Infection prevention $\&$ management}

Thirty studies reported on this important aspect of neonatal care [102-106,109,111-115,117,122,123,130,133147]. Topical emollient therapy was suggested in the data analysis for the Every Newborn series to have a significant impact on neonatal mortality [148], however, this has been challenged by subsequent research. A recent Cochrane review including 5 studies published in the last 5 years showed no significant reduction in neonatal mortality ( $\mathrm{RR}=0.94,95 \% \mathrm{CI}=0.81-1.08)$ or incidence of invasive bacterial infection [149].

Probiotics and synbiotics have been studied for their role in preventing necrotizing enterocolitis (NEC) and associated mortality. A randomized controlled trial of 4000 newborns in India showed a 40\% reduction in a combined endpoint of sepsis/death $(\mathrm{RR}=0.60,95 \% \mathrm{CI}=0.48-0.74)$ associated with once daily administration of the probiotic Lactobacillus Reuteri [103]. Importantly this study excluded neonates born before 35 weeks gestation or $<2000 \mathrm{~g}$ in birthweight however a meta-analysis of probiotics in preterm infants in LMICs also showed a significant reduction in all-cause mortality $(R R=0.73,95 \% C I=0.59-0.90)$, incidence of NEC $(R R=0.46,95 \%$ $\mathrm{CI}=0.34-0.61)$ and incidence of late-onset neonatal sepsis $(\mathrm{RR}=0.80,95 \% \mathrm{CI}=0.71-0.91)$ [102] .

\section{Respiratory support}

We found 25 studies exploring respiratory support in LMICs [150-173]. The implementation of bubble continuous positive airways pressure devices (bCPAP) has been shown to be feasible in multiple LMIC settings, in secondary and tertiary level facilities [151,153-156,160,163,166,170,171]. 2 recent systematic reviews have examined the impact of this on neonatal outcomes, specifically in LMICs $[152,161]$. Although there were no RCT data on mortality available, a pooled analysis of 4 observational studies showed bCPAP to have a major impact on mortality in preterm neonates ( $\mathrm{OR}=0.34,95 \% \mathrm{CI}=0.14-0.82$ ) [161]. Importantly, a study from a neonatal unit in Malawi showed that this beneficial effect is strongly mediated by neonatal temperature, with hypothermic neonates failing to respond to bCPAP [174], emphasising the importance of basic neonatal care as a requirement prior the addition of more complex interventions such as bCPAP. 
Nine middle-income country studies were identified investigating the feasibility and impact of surfactant administration to premature neonates with neonatal respiratory distress syndrome (RDS) [150,151,158,159,16 $2,167,169,172]$.Predominantly these were small-scale studies of either differing methods of surfactant administration or comparisons of early vs late administration, both of which showing inconsistent results. It appears that surfactant is a feasible intervention to implement in LMICS, and a meta-analysis showed reductions in mortality in eligible infants comparable with those observed in high-income settings ( $\mathrm{RR}=0.67,95 \% \mathrm{CI}=0.57$ 0.79) $[159,175]$. Unfortunately, however, the high cost of the intervention and the infrastructure required in terms of delivery and ventilatory support is likely to leave surfactant beyond the reach of many low-income facilities for some time to come [159].

\section{Community mobilization}

We identified 11 studies investigating aspects of community mobilization with regards to neonatal mortality reduction $[25,59,63,107,131,176-181]$. These largely focused on predominantly maternal interventions (eg, participatory women's groups) and so are discussed above in the maternal interventions section.

\section{Cardiovascular support}

There were two studies of interventions for cardiovascular therapy [182,183]. A Brazilian study of very low birthweight neonates with patent ductus arteriosus (PDA) showed a significant mortality reduction with pharmacological or surgical treatment of PDA compared with conservative management [182]. A Cochrane review reported low-quality evidence suggesting paracetamol to be as effective as indomethacin in PDA closure however highlighted insufficient follow-up data to establish evidence on neurodevelopmental outcomes of this treatment [183].

\section{Training programmes $\&$ resuscitation}

Nineteen studies described implementation of training programmes [63,86,128,130,139,141,157,181,184195]. Thirteen of these described training programmes in neonatal resuscitation, specifically the Helping Babies Breathe programme (HBB). Neonatal resuscitation was identified as a potentially very impactful intervention in the Every Newborn series. Studies investigating this subsequently have highlighted additional complexity in low-resource settings. A large study of HBB implementation in Nepal involving over 40000 deliveries showed a significant reduction in intrapartum stillbirth and neonatal mortality in the 1st day of life however, no reduction in overall perinatal mortality (stillbirth or neonatal death within 7 days of life) [186,192].Other studies in India, Kenya and Tanzania, and 2 recent meta-analyses showed similar results [184,185,194-196]. These data suggest that although HBB training was effective in prolonging life of babies with intrapartum-related complications or those previously categorised as fresh stillbirths, the quality and availability of care in the postnatal period was not sufficient to sustain these gains [192]. In addition, although babies with severe asphyxia may have been successfully resuscitated, in reality the preferred intervention would have been earlier delivery by timely Caesarean-section. This highlights the importance of a systems-based approach to improving the continuum of care.

\section{Health systems strengthening $\&$ guideline implementation}

Twenty studies were identified that described aspects of guideline implementation or health systems strengthening to improve outcomes of preterm babies in LMICs $[59,63,104,128,130,135,142,144,145,157,177$, $178,180,181,188,191,197-200]$.

One initiative which targeted several different health system issues and showed impressive results was the development of a health partnership between 4 hospitals ( 2 university, 2 district) in Rwanda and a team of neonatologists and neonatal nurses from the United Kingdom [157]. They conducted a detailed needs assessment in all facilities and identified 6 major areas of need including nutrition, respiratory support, thermoregulation, and enhanced record keeping. Targeted intervention packages were developed for each of these needs, with examples being KMC utilisation for thermoregulation and training staff in breast feeding support and developing systems for storing expressed breast milk to improve nutrition. The total budget of the project was only US\$45 000 and yet overall in-hospital neonatal mortality decreased from $23.6 \%$ to $21.7 \%$ in university hospitals and from $10 \%$ to $8.1 \%$ in district hospitals $(P=0.056)$.

On a smaller scale Harris et al reported results from a pre- post-implementation trial aiming to improving neonatal outcomes in a single Ugandan neonatal unit [198]. Protocols for management of unwell newborns were developed using literature and local consensus and disseminated through ward meetings and regular ward- 
based teaching. Audits at 3 and 6 years showed a reduction of neonatal mortality from 0.58 deaths per admission to 0.26 and 0.17 deaths respectively. The sustained nature of this improvement without major investment in infrastructure is particularly striking.

\section{DISCUSSION}

This review has highlighted a set of measures with a strong evidence base and the potential to prevent a large proportion of stillbirth and preterm birth, and reduce neonatal mortality in low- and middle- income settings. Maternal interventions found to be successful were antenatal care, multiple micronutrient supplementation and malaria prevention. Successful neonatal interventions included vitamin A supplementation, probiotics and early breastfeeding initiation, KMC and bCPAP. Staff training and guideline implementation and community mobilisation were beneficial for both mothers and neonates. Many of these interventions are relatively simple and it is clear that new innovations are not a priority- we need innovative ways to successfully implement the interventions we know can work.

\section{Strengths and limitations}

Our study has several important strengths. Our explicit focus on LMIC evidence delivered an important set of conclusions with direct applicability to LMIC policy-makers, something that is increasingly crucial in the context of the ACT trial and other recent findings. By intentionally limiting our review to the last 5 years we were able to focus on changes to the evidence base since the Every Newborn series and highlight important interventions with new recommendations or that merit further investigation such as optimising neonatal thermal care, and minimising indoor air pollution. The production of evidence gap maps is a relatively novel interactive way of presenting this visually and can play an important role going forward in understanding the current state of evidence for maternal and newborn health interventions. By investigating maternal and newborn interventions in conjunction we were able to draw important conclusions regarding the continuum of care involved and the role of whole-system approaches to improving outcomes.

There are also several limitations to consider. First, although the review was intentionally limited to the last 5 years to focus on changes to the evidence base since the Every Newborn series, this could have resulted in missing important evidence generated prior to 2013 but not included in the Every Newborn publications however we feel this is unlikely. We only included maternal interventions delivered to pregnant women, thereby excluding other population-level interventions delivered to all women of childbearing age which may have an impact on preterm birth and stillbirth incidence (eg, access to birth control) [201,202]. LMICs are a broad and heterogeneous group and some of our conclusions may not be transferable to LMIC contexts other than those where the studies took place.

\section{Strategies for stillbirth reduction}

Many stillbirths can be prevented by relatively simple measures. Facilitating condition recognition and diagnosis of high-risk pregnancy is the cornerstone and this can in large part be achieved by enabling early antenatal care attendance, providing appropriate staff training and guidelines, and ensuring women are able to access the health care they require. Additionally, the ability to perform timely delivery is crucial- this means the ability to induce labour or perform emergency Caesarean-section without undue delay caused by lack of facilities, limited staffing, or infrastructure (eg, transport) problems.

Access to quality antenatal care is a key priority and has been clearly demonstrated to reduce perinatal mortality $[17,20,22,26,203]$. Data from Ghana showed that receiving high-quality antenatal care halved risk of stillbirth as it enabled provision of malarial treatment and prophylaxis, screening for anaemia, helminth management and blood pressure monitoring. In addition it facilitated Prevention of Mother to Child Transmission of HIV (PMTCT) and syphilis detection and treatment. It also allowed provision of nutritional supplements and an opportunity for educating women about ways to improve their health and recognition of danger signs in pregnancy [17]. Modelling has predicted that the provision of 10 basic services in antenatal care could avert $45 \%$ of all stillbirths [204]. As part of strategies to reduce both perinatal and maternal mortality, there has been increasing efforts in many LMICs to encourage women to give birth in health facilities in order to allow early complication recognition and life-saving interventions. However, in many settings facility based delivery has been associated with paradoxically worse outcomes compared with home delivery $[22,87,90,93]$. This is multifactorial, and in part can be attributed to increased likelihood of high-risk cases being selected for facility 
delivery. In Ethiopia, a cohort study of 4442 women found that women who experienced intrapartum complications were twice as likely to deliver in a health facility than those who did not, explaining in part the fact there was no stillbirth reduction in facility births [22]. However, this is not the only modifying factor and quality of obstetric care available is likely to be a key determinant. One study using Demographic Health Survey (DHS) data from Malawi for example found that, even when controlling for the risk profile of patients, facility delivery conferred poorer outcomes for both the mother and the baby [90]. The additional risk burden is likely to be attributable to the fact that increasing uptake of facility delivery does not translate into increasing availability of high quality CEmONC care. This has been demonstrated in multiple low- and middle-income settings where, even when women are able to reach health facilities, access to the care they need is limited by lack of medical supplies such as blood, or lack of staff with sufficient expertise and training [205]. This highlights the need for coordinated systems and infrastructure development in conjunction with service provision in order to provide the necessary care.

\section{Strategies for preterm birth reduction}

Preterm birth reduction is complex and involves national level commitment to improving maternal health and well-being. Specific interventions with a strong evidence base in LMICs include optimising nutritional intake, which is important for both micro- and macro-nutrients, and there is a wealth of evidence for different nutritional supplements which reduce preterm birth rates [5,36,42,43,46,47,55,56,206]. Appropriate HIV management is also important [96],as is adequate malarial prophylaxis [71,73,75].

Strategies to improve women's health at a population level however must be in tandem with advocacy for women's rights. Intimate partner violence is a threat to women's well-being worldwide and lack of female empowerment means many women are unable to make safe decisions about their reproductive health. Improving access to contraception, family planning, and abortion is crucial in forwarding female- and therefore maternal health.

\section{Strategies for neonatal mortality reduction}

Our findings have shown a number of interventions which can reduce neonatal mortality. Early initiation of breastfeeding, KMC and probiotics are all simple, low-cost interventions which could be easily implemented at low cost. There are also promising results from use of bCPAP and surfactant. Introduction of HBB training showed promise in mortality reduction however also served to highlight the need for systems strengthening alongside HCW training.

Kanagroo Mother Care (KMC) to aid thermal regulation in babies $<2000 \mathrm{~g}$ birthweight has been rolled out across LMICS as part of the Every Newborn Action Plan [207]. Currently in the majority of settings KMC is initiated only on stable neonates once they have completed any required treatment and so unstable babies on treatment remain at high risk of hypothermia. The results are awaited of an ongoing WHO multi-site LMIC trial of immediate KMC (i-KMC) where KMC is initiated immediately after birth regardless of other ongoing treatments [208] and may provide an important recommendation of the benefit of KMC even in unstable babies in the first days of life.

This review has also shown important changes to the evidence base subsequent to the Every Newborn Action Plan series of reviews and emphasised the importance for LMIC health policy development of considering evidence derived in LMICs. We have derived important conclusions regarding general and intervention-specific barriers and enabling factors to implementation, which are essential to consider when developing new maternal and newborn health policy initiatives.

\section{Implementation challenges}

Our review has identified that while much of the burden of stillbirth and preterm birth can be prevented by interventions already available, the real challenge is in the successful implementation of these strategies. A number of common themes arose in our review highlighting some of the key areas which must be addressed in order to create successful strategies.

\section{Health systems strengthening}

Many of the deficits in health care in LMICs are due to weak health care systems and a lack of robust protocols and support systems. These are often deeply ingrained, multi-faceted and challenging to address, however without such attempts, only limited improvement in outcomes can be achieved. 
Quality improvement projects are a burgeoning area of research in LMICs as they require relatively low resource input and can effectively target areas of need. Success is however dependant on investment of facility staff in the cycle and in the ongoing re-evaluation of outcome measures [83]. Some successful attempts to improve this have included use of "local champions" and also leadership boards allowing inter-site comparisons [83]. Several studies delivered and evaluated HBB through QI methodological approaches. The value of these were apparent, one example being the utilisation of intermediate data in the form of 'run charts' to highlight the impact of staff turnover on outcomes and supplement advocacy at hospital administration level [209]. In an era of renewed global focus on quality of care, pragmatic trials and learning health systems, these approaches are likely to prove highly important [210-212].

One initiative which targeted several different health system issues and showed impressive results was the development of a health partnership between 4 hospitals (2 university, 2 district) in Rwanda and a team of neonatologists and neonatal nurses from the United Kingdom [157]. They conducted a detailed needs assessment in all facilities and identified 6 major areas of need. Targeted intervention packages were developed for each of these needs, with examples being KMC utilisation for thermoregulation and training staff in breast feeding support and developing systems for storing expressed breast milk to improve nutrition. The total budget of the project was only US $\$ 45000$ and yet overall in-hospital neonatal mortality decreased from $23.6 \%$ to $21.7 \%$ in university hospitals and from $10 \%$ to $8.1 \%$ in district hospitals $(P=0.056)$. The project emphasized the potential for locally-driven health systems strengthening through partnership alongside government support and also highlighted the important barrier to training of high staff turnover which hampered the development of institutional memory with regards to new working practices.

\section{Guideline implementation}

In many LMICs, the majority of health care is not performed by doctors but by clinical officers and other lower skilled health care workers. There has been much success in introducing algorithmic approaches to health care, allowing lower skilled workers with less expertise to assess and manage sick patients, however for guidelines to be successful, they must be implementable and accessible to the staff who use them. Relevant care providers should be identified and involved in establishing standards and developing guidelines and protocols which are locally relevant. This ensures guidelines are applicable, attainable, and gives clinicians ownership over them, meaning they are more likely to be adhered to [84].

The most successful models were those combining guidelines with training programs and education, and much greater levels of adherence were achieved $[18,79,84]$. This was augmented further with the use of audit cycles to evaluate the guidelines and improve on them and their usage over time [84]. Ultimately Guidelines will only lead to improved quality of care if they are used in daily clinical practice therefore staff need to be supported in order for this to happen with reminders, monitoring and feedback [18].

\section{Staff training}

Staff training is imperative in achieving optimal maternal and neonatal care. A systematic literature review evaluating perinatal mortality found that across 9 centres in Sub-Saharan Africa, perinatal mortality was 21\% in facilities than with home deliveries [87]. Although some of this may be because more complex pregnancies are more likely to attend facilities for delivery, much of this is due to the inability of staff to appropriately manage complications. In Ethiopia for example, only 1.3\% of facilities were able to provide Basic Emergency Obstetric and Neonatal Care (BEmONC) [22].

One-off staff training programmes rarely produced successful outcomes and there is a need for repetition of training allowing reinforcement of new skills and knowledge over time $[79,86]$. Training should take place in the context of regular audits of outcomes allowing identification of successes and also of failures to feedback to staff allowing continued development of knowledge and skills [79].

It is crucial to involve authorities such as Ministry of Health or hospital administrative staff from an early stage to ensure the staff are supported and encouraged to attend training sessions, and also to adopt new practices. Administrative bodies must also be involved to enable the supply of the necessary equipment to implement new skills and practice $[79,86]$.

Necessary staff must be identified and enabled to attend the training session. In health facilities, a critical mass of training staff is needed in order to effect systems change [86]. This is particularly challenging to achieve in settings where staff retention is poor and turnover is high, as is frequently the case in low resource health fa- 
cilities [214].Strategies need to be put in place to incentivise staff retention or facilitate frequent training provision and again this will mandate involving administrative staff and relevant officials from the outset [82].

As well as improving the skillset of staff, it is important to involve women in the outcomes of their pregnancy and to empower them with increased skills and advocacy to effect change both on their own outcomes, but also the wider health services in their community [85]. When trying to improve maternal and child health, this must take place in parallel with increasing the voice and the rights of women, and education is the cornerstone of this approach.

\section{Community Groups}

Community groups and community mobilisation are examples of relatively low-cost, low-resource, low-intensity innovations with the potential for significant effect. There are various models however they are mainly based around participatory learning and action cycles run within small groups of women led by a trained (and usually salaried) facilitator [65]. This model enables identification and prioritisation of problems, planning and implementation of strategies which are locally feasible, and re-assessment and evaluation [65].

There are a number of reasons why groups such as these can be so effective. They require minimal resources and empower communities to address locally relevant health determinants. They facilitate capacity building at a community level but also enable increased advocacy for local issues [178]. It is worth mentioning however, a large RCT performed as part of The Global Network study which implemented a package of interventions including community mobilisation and also health centre quality improvement and staff training. Despite being rolled out across five countries with considerable funding and ongoing support, they saw no improvement in their outcome measures over a two year period [61]. There are a number of possible explanations for this however it highlights the fact that, as with many of the interventions discussed in this review, community mobilisation can only have a significant impact on outcomes if it occurs alongside improvements in the abilities of the health service to manage obstetric emergencies effectively and in a timely manner.

\section{Research as part of routine care}

Much of the emerging LMIC data highlighted in this review emphasizes the need for whole-system approaches to delivering individual interventions, and the concept of creating 'learning health systems' (LHS) has much to offer in delivering this and driving health system improvement in LMICs. In an LHS, data capture processes are optimised and embedded into routine care, clinical data entered once can then be repurposed many times for administration, quality improvement and research [214]. Although the technological and human resource infrastructure required to implement LHS are often lacking in LMIC contexts [215], there are important examples of where this has already been shown to be possible, such as the Clinical Information Network of paediatric departments in Kenya [210]. In addition the current lack of infrastructure offers the opportunity to implement LHS now, rather than retrofit them as has been necessary and very costly in many high-income contexts [216] . The potential for using LHS to conduct rapid pragmatic trials at low cost is particularly appealing in LMICs given the lack of evidence base for many intervention in these settings, and can support ongoing developments in LMIC quality improvement methodology as described above. LMICs stand potentially to benefit the most from learning health systems as a means of unifying fragmented approaches and producing systems capable of continuous improvement.

\section{CONCLUSION}

Using intervention evidence generated in LMICs, this review has highlighted several areas regarding preterm birth and stillbirth reduction, and the management of small and ill newborns, where the evidence base has changed significantly since the Every Newborn Action Plan. The key point to emphasise is the potential to deliver marked reductions in preterm birth and stillbirth with relatively simple interventions, however these must be delivered as part of an approach of a whole-system strengthening to be effective. Learning health systems can offer an opportunity to bring the current fragmented context in many LMIC health systems together and provide important means of understanding implementation challenges and running rapid pragmatic trials, delivering locally relevant data at a low cost and driving continual improvement in quality of care. 


Funding: This research was funded by the National Institute for Health Research (NIHR) (GHR Project: 17/63/08 DIP-
LOMATIC collaboration) using UK aid from the UK Government to support global health research.
Ethics: Ethics approval not required as only published aggregated data used.
Authorship contributions: EW - literature search, synthesis of results, writing of paper; DW - literature search, synthesis
of results, writing of paper; SM- conceptualisation, editing of paper; BM - editing of paper; EC: editing of paper; ALN-M:
editing of paper; Luis Gadama: editing of paper; GG: editing of paper; MM: editing of paper; MM: editing of paper; FT:
editing of paper; QD: editing of paper; KK: editing of paper; PMK: editing of paper; SW: coordination of project and edit-
ing of paper; MC: editing of paper; BF: editing of paper; JEN: conceptualisaion, editing of paper; RMR: conceptualisation,
editing of paper, overall decision making and review.
Competing interests: The authors completed the ICMJE Unified Competing Interest form (available upon request from
the corresponding author), and declare no conflicts of interest.
Additional material
Online Supplementary Document

1 Goldenberg RL, McClure EM. Improving Birth Outcomes in Low- and Middle-Income Countries. N Engl J Med. 2017;377:23878. Medline:29236634 doi:10.1056/NEJMe1713831

2 Liu L, Oza S, Hogan D, Chu Y, Perin J, Zhu J, et al. Global, regional, and national causes of under-5 mortality in 2000-15: an updated systematic analysis with implications for the Sustainable Development Goals. Lancet. 2016;388:3027-35. Medline:27839855 doi:10.1016/S0140-6736(16)31593-8

3 Lawn JE, Blencowe H, Oza S, You D, Lee ACC, Waiswa P, et al. Every newborn: Progress, priorities, and potential beyond survival. Lancet. 2014;384:189-205. Medline:24853593 doi:10.1016/S0140-6736(14)60496-7

4 Lawn JE, Blencowe H, Waiswa P, Amouzou A, Mathers C, Hogan D, et al. Stillbirths: Rates, risk factors, and acceleration towards 2030. Lancet. 2016;387:587-603. Medline:26794078 doi:10.1016/S0140-6736(15)00837-5

5 Bhutta ZA, Das JK, Bahl R, Lawn JE, Salam R, Paul VK, et al. Can available interventions end preventable deaths in mothers, newborn babies, and stillbirths, and at what cost? Lancet. 2014;384:347-70. Medline:24853604 doi:10.1016/S01406736(14)60792-3

6 World Health Organization. Recommendations on Maternal Health. Geneva: WHO; 2017.

7 World Health Organization. Recommendations on Newborn Health. Geneva: WHO; 2017.

8 World Health Organization. WHO Recommendations on Interventions to Improve Preterm Birth Outcomes. Geneva: WHO; 2015.

9 Althabe F, Belizán JM, McClure EM, Hemingway-Foday J, Berrueta M, Mazzoni A, et al. A population-based, multifaceted strategy to implement antenatal corticosteroid treatment versus standard care for the reduction of neonatal mortality due to preterm birth in low-income and middle-income countries: the ACT cluster-randomised trial. Lancet. 2015;385:629-39. Medline:25458726 doi:10.1016/S0140-6736(14)61651-2

10 Althabe F, Thorsten V, Klein K, McClure EM, Hibberd PL, Goldenberg RL, et al. The Antenatal Corticosteroids Trial (ACT)'s explanations for neonatal mortality - a secondary analysis. Reprod Health. 2016;13:62. Medline:27220987 doi:10.1186/ s12978-016-0175-3

11 Maitland K, Kiguli S, Opoka RO, Engoru C, Olupot-Olupot P, Akech SO, et al. Mortality after Fluid Bolus in African Children with Severe Infection. N Engl J Med. 2011;364:2483-95. Medline:21615299 doi:10.1056/NEJMoa1101549

12 World Health Organization. Neonatal mortality. Available: https://www.who.int/gho/child_health/mortality/neonatal_text/en/. Accessed: 19 December 2019.

13 World Bank. World Bank Country Lending Groups. 2018. Available: https://datahelpdesk.worldbank.org/knowledgebase/articles/906519-world-bank-country-and-lending-groups. Accessed: 19 December 2019.

14 Bangladesh I, Kenya, Nigeria P. Geographic location. 2017.

15 Vogel JP, Souza JP, Guelmezoglu AM, Mori R, Lumbiganon P, Qureshi Z, et al. Use of antenatal corticosteroids and tocolytic drugs in preterm births in 29 countries: an analysis of the WHO Multicountry Survey on Maternal and Newborn Health. Lancet. 2014;384:1869-77. Medline:25128271 doi:10.1016/S0140-6736(14)60580-8

16 3ie. Evidence gap maps. Available: https://www.3ieimpact.org/evidence-hub/evidence-gap-maps. Accessed: 5 February 2020.

17 Afulani PA. Determinants of stillbirths in Ghana: does quality of antenatal care matter? BMC Pregnancy Childbirth. 2016;16:132. Medline:27255155 doi:10.1186/s12884-016-0925-9

18 Amoakoh-Coleman M, Klipstein-Grobusch K, Agyepong IA, Kayode GA, Grobbee DE, Ansah EK. Provider adherence to first antenatal care guidelines and risk of pregnancy complications in public sector facilities: a Ghanaian cohort study. BMC Pregnancy Childbirth. 2016;16:369. Medline:27881104 doi:10.1186/s12884-016-1167-6

19 Asundep NN, Jolly PE, Carson A, Turpin CA, Zhang K, Tameru B. Antenatal care attendance, a surrogate for pregnancy outcome? The case of Kumasi, Ghana. Matern Child Health J. 2014;18:1085-94. Medline:23948806 doi:10.1007/s10995-013$1338-2$

20 McDiehl R, Boatin A, Riley L, Ngonzi J, Bebell L. Does screening, treatment and prevention for infectious diseases by attending $\geq 4$ antenatal care visits decrease the risk of stillbirth and poor birth outcomes in rural uganda? Am J Obstet Gynecol. 2017;217:739-40. doi:10.1016/j.ajog.2017.08.037 
21 Atnafu H, Zelalem B, Kinfu H, Tadasse M, Mohammed A, Ballard KD. Can a community-based maternal care package in rural Ethiopia increase the use of health facilities for childbirth and reduce the stillbirth rate? Int J Womens Health. 2016;8:421-8. Medline:27574471 doi:10.2147/IJWH.S104160

22 Ballard K, Belete Z, Kinfu H, Tadesse M, Amin M, Atnafu H. The effect of prenatal and intrapartum care on the stillbirth rate among women in rural Ethiopia. Int J Gynaecol Obstet. 2016;133:164-7. Medline:26899816 doi:10.1016/j.ijgo.2015.09.027

23 Beauclair R, Petro G, Myer L. The association between timing of initiation of antenatal care and stillbirths: a retrospective cohort study of pregnant women in Cape Town, South Africa. BMC Pregnancy Childbirth. 2014;14:204. Medline:24923284 doi:10.1186/1471-2393-14-204

24 Biswas A, Anderson R, Doraiswamy S, Abdullah ASM, Purno N, Rahman F, et al. Timely referral saves the lives of mothers and newborns: Midwifery led continuum of care in marginalized teagarden communities - A qualitative case study in Bangladesh. F1000Res. 2018;7:365. Medline:29707205 doi:10.12688/f1000research.13605.1

25 Lassi ZS, Middleton PF, Bhutta ZA, Crowther C. Strategies for improving health care seeking for maternal and newborn illnesses in low- and middle-income countries: A systematic review and meta-analysis. Glob Health Action. 2016;9:31408. Medline:27171766 doi:10.3402/gha.v9.31408

26 Mbuagbaw L, Medley N, Darzi AJ, Richardson M, Garga HK, Ongolo-Zogo P. Health system and community level interventions for improving antenatal care coverage and health outcomes. Cochrane Database Syst Rev. 2015;CD010994. Medline:26621223 doi:10.1002/14651858.CD010994.pub2

27 Mbuyita S, Tillya R, Godfrey R, Kinyonge I, Shaban J, Mbaruku G. Effects of introducing routinely ultrasound scanning during Ante Natal Care (ANC) clinics on number of visits of ANC and facility delivery: a cohort study. Arch Public Heal. 2015;1-6.

28 Nimi T, Fraga S, Costa D, Campos P, Barros H. Prenatal care and pregnancy outcomes: A cross-sectional study in Luanda, Angola. Int J Gynaecol Obstet. 2016;135 Suppl 1:S72-8. Medline:27836089 doi:10.1016/j.ijgo.2016.08.013

29 Lassi ZS, Middleton PF, Bhutta ZA, Crowther C. Strategies for improving health care seeking for maternal and newborn illnesses in low- and middle-income countries: a systematic review and meta-analysis. Glob Health Action. 2016;9:31408. Medline:27171766 doi:10.3402/gha.v9.31408

30 Goldenberg R, Nathan R, Swanson D, Saleem S, Mirza W, Esamai F, et al. Routine antenatal ultrasound in low- and middle-income countries: first look - a cluster randomised trial. BJOG An Int J Obstet Gynaecol. 2018;1-9.

31 Lee AC, Mullany LC, Quaiyum M, Mitra DK, Labrique A, Christian P, et al. Effect of population-based antenatal screening and treatment of genitourinary tract infections on birth outcomes in Sylhet, Bangladesh (MIST): a cluster-randomised clinical trial. Lancet Glob Health. 2019;7:e148-59. Medline:30554751 doi:10.1016/S2214-109X(18)30441-8

32 Bellad MB, Hoffman M, Mallapur A, Charantimath U, Katageri G, Ganachari M, et al. Clindamycin to reduce preterm birth in a low resource setting: a randomised placebo- controlled clinical trial. BJOG. 2018;125:1601-9. Medline:29790266 doi:10.1111/1471-0528.15290

33 Gupta S, Tripathi R, Singh N, Bhalla P, Ramji S, Mala YM. Pregnancy outcome in asymptomatic women with abnormal vaginal flora without any treatment and after treatment with vaginal clindamycin and clotrimazole: A randomised controlled trial. S Afr J Obstet Gynaecol. 2013;19:35-8.

34 Li Y, Zhu L, Du L, Qu L, Jiang W, Xu B. Effects on preventing mother-to-child transmission of syphilis and associated adverse pregnant outcomes: a longitudinal study from 2001 to 2015 in Shanghai, China. BMC Infect Dis. 2017;17:626. Medline:28923018 doi:10.1186/s12879-017-2721-1

35 Vaivada T, Gaffey MF, Das JK, Bhutta ZA. Evidence-based interventions for improvement of maternal and child nutrition in low-income settings: what's new? Curr Opin Clin Nutr Metab Care. 2017;20:204-10. Medline:28207425 doi:10.1097/ MCO.0000000000000365

36 Muriel P, Sushama C, Cardoso PM. The Effect of Vitamin E and Vitamin C on the Prevention of Preeclampsia and Newborn Outcome: A Case - Control Study. J Obstet Gynaecol India. 2016;66:271-8. Medline:27651616 doi:10.1007/s13224-016-0885-z

37 Li Z, Ye R, Zhang L, Li H. Periconceptional folic acid supplementation and the risk of preterm births in China: a large prospective cohort study. Int J Epidemiol. 2014;43:1132-9. Medline:24603317 doi:10.1093/ije/dyu020

38 Liu JM, Mei Z, Ye R, Serdula MK, Ren A, Cogswell ME. Micronutrient Supplementation and Pregnancy Outcomes Double-Blind Randomized Controlled Trial in China. JAMA Intern Med. 2013;173:276-82. Medline:23303315 doi:10.1001/jamainternmed.2013.1632

39 Mccauley ME, Van Den Broek N, Dou L, Othman M. Vitamin A supplementation during pregnancy for maternal and newborn outcomes. Cochrane Database Syst Rev. 2015;11:CD008666. Medline:26503498 doi:10.1002/14651858.CD008666.pub3

40 Mojibian M, Soheilykhah S, Moghadam J. The effects of vitamin D supplementation on maternal and neonatal outcome: A randomized clinical trial. Iran J Reprod Med. 2015;13:687-96. Medline:26730243

41 Mosha D, Liu E, Hertzmark E, Chan G, Sudfeld C, Masanja H, et al. Dietary iron and calcium intakes during pregnancy are associated with lower risk of prematurity, stillbirth and neonatal mortality among women in Tanzania. Public Health Nutr. 2017;20:678-86. Medline:27819215 doi:10.1017/S1368980016002809

42 Nossier SA, Naeim NE, El-sayed NA, Zeid AAA. The effect of zinc supplementation on pregnancy outcomes: a double-blind, randomised controlled trial, Egypt. Br J Nutr. 2015;114:274-85. Medline:26099195 doi:10.1017/S000711451500166X

43 Ota E, Mori R, Middleton P, Mahomed K, Miyazaki C, Za B, et al. Zinc supplementation for improving pregnancy and infant outcomes. Cochrane Database Syst Rev. 2012;7:1.

44 Peña-Rosas JP, De-Regil LM, Malave HG, Flores-Urrutia MC, Dowswell T. Intermittent oral iron supplementation during pregnancy. Cochrane Database Syst Rev. 2015;2015:CD009997. Medline:26482110

45 Ramakrishnan U, Nguyen PH, Gonzalez-Casanova I, Pham H, Hao W, Nguyen H, et al. Neither Preconceptional Weekly Multiple Micronutrient nor Iron-Folic Acid Supplements Affect Birth Size and Gestational Age Compared with a Folic Acid Sup- 
plement Alone in Rural Vietnamese Women: A Randomized Controlled Trial. J Nutr. 2016;146:1445S-52S. Medline:27281806 doi:10.3945/jn. 115.223420

46 Sablok A, Batra A, Thariani K, Batra A, Bharti R, Aggarwal AR. Supplementation of vitamin D in pregnancy and its correlation with feto-maternal outcome. Clin Endocrinol (Oxf). 2015;83:536-41. Medline:25683660 doi:10.1111/cen.12751

47 Haider BA, Bhutta ZA. Multiple-micronutrient supplementation for women during pregnancy. Cochrane Database Syst Rev. 2017;4:CD004905. Medline:28407219

48 Smith ER, Shankar AH, Wu LS-F, Aboud S, Adu-Afarwuah S, Ali H, et al. Modifiers of the effect of maternal multiple micronutrient supplementation on stillbirth, birth outcomes, and infant mortality: a meta-analysis of individual patient data from 17 randomised trials in low-income and middle-income countries. Lancet Glob Health. 2017;5:e1090-100. Medline:29025632 doi:10.1016/\$2214-109X(17)30371-6

49 West KP, Shamim AA, Mehra S, Labrique AB, Ali H, Shaikh S, et al. Effect of Maternal Multiple Micronutrient vs Iron-Folic Acid Supplementation on Infant Mortality and Adverse Birth Outcomes in Rural Bangladesh The JiVitA-3 Randomized Trial. JAMA. 2014:312:2649-58. Medline:25536256 doi:10.1001/jama.2014.16819

50 Zheng JS, Guan Y, Zhao Y, Zhao W, Tang X, Chen H, et al. Pre-conceptional intake of folic acid supplements is inversely associated with risk of preterm birth and small-for-gestational-age birth: a prospective cohort study. Br J Nutr. 2016;115:509-16. Medline:26651997 doi:10.1017/S0007114515004663

51 Haider BA, Olofin I, Wang M, Spiegelan D, Ezzati M, Fawzi W. Anaemia, prenatal iron use, and risk of adverse pregnancy outcomes: systematic review and. BMJ. 2013;346:f3443. Medline:23794316 doi:10.1136/bmj.f3443

52 He Y, Pan A, Hu FB, Ma X. Folic acid supplementation, birth defects, and adverse pregnancy outcomes in Chinese women: a population-based mega-cohort study. Lancet. 2016;388:S91. doi:10.1016/S0140-6736(16)32018-9

53 Hemminki E, Nwaru BI, Salomé G, Parkkali S, Abacassamo F, Augusto O, et al. Is selective prenatal iron prophylaxis better than routine prophylaxis: fi nal results of a trial (PROFEG) in Maputo, Mozambique. BMJ Open. 2016;6:e011280. Medline:27297013 doi:10.1136/bmjopen-2016-011280

54 Hossain N, Kanani FH, Ramzan S, Kausar R, Ayaz S, Khanani R, et al. Obstetric and Neonatal Outcomes of Maternal Vitamin D Supplementation: Results of an Open- Label, Randomized Controlled Trial of Antenatal Vitamin D Supplementation in Pakistani Women. J Clin Endocrinol Metab. 2014;99:2448-55. Medline:24646102 doi:10.1210/jc.2013-3491

55 Janmohamed A, Karakochuk CD, Boungnasiri S, Chapman GE, Janssen PA, Brant R, et al. Prenatal supplementation with Corn Soya Blend Plus reduces the risk of maternal anemia in late gestation and lowers the rate of preterm birth but does not significantly improve maternal weight gain and birth anthropometric measurements in rural Cambodian. Am J Clin Nutr. 2016;103:559-66. Medline:26739037 doi:10.3945/ajcn.114.104034

56 Kang Y, Dang S, Zeng L, Wang D, Li Q, Wang J, et al. Multi-micronutrient supplementation during pregnancy for prevention of maternal anaemia and adverse birth outcomes in a high-altitude area: a prospective cohort study in rural Tibet of China. Br J Nutr. 2017;118:431-40. Medline:28980891 doi:10.1017/S000711451700229X

57 Kiondo P, Wamuyu-maina G, Wandabwa J, Bimenya GS, Tumwesigye NM. The effects of vitamin C supplementation on pre-eclampsia in Mulago Hospital, Kampala, Uganda: a randomized placebo controlled clinical trial. BMC Pregnancy Childbirth. 2014;14:283. Medline:25142305 doi:10.1186/1471-2393-14-283

58 Colbourn T, Nambiar B, Kim S, Bondo A, Banda L, Makwenda C, et al. Cost-effectiveness and affordability of community mobilisation through women' s groups and quality improvement in health facilities (MaiKhanda trial) in Malawi. Cost Eff Resour Alloc. 2015;13:1-15. Medline:25649323 doi:10.1186/s12962-014-0028-2

59 Fottrell E, Azad K, Kuddus A, Younes L, Shaha S, Nahar T, et al. The Effect of Increased Coverage of Participatory Women's Groups on Neonatal Mortality in Bangladesh A Cluster Randomized Trial. JAMA Pediatr. 2013;167:816-25. Medline:23689475 doi:10.1001/jamapediatrics.2013.2534

60 Prost A, Colbourn T, Seward N, Azad K, Coomarasamy A, Copas A, et al. Women's groups practising participatory learning and action to improve maternal and newborn health in low-resource settings: a systematic review and meta-analysis. Lancet. 2013;381:1736-46. Medline:23683640 doi:10.1016/S0140-6736(13)60685-6

61 Pasha O, McClure EM, Wright LL, Saleem S, Goudar SS, Chomba E, et al. A combined community-and facility-based approach to improve pregnancy outcomes in low-resource settings: a Global Network cluster randomized trial. BMC Med. 2013;11:215. Medline:24090370 doi:10.1186/1741-7015-11-215

62 August F, Pembe AB, Kayombo E, Mbekenga C, Axemo P, Darj E. Birth preparedness and complication readiness - a qualitative study among community members in rural Tanzania. Glob Health Action. 2015;8:26922. Medline:26077145 doi:10.3402/ gha.v8.26922

63 Lewycka S, Mwansambo C, Rosato M, Kazembe P, Phiri T, Mganga A, et al. Effect of women's groups and volunteer peer counselling on rates of mortality, morbidity, and health behaviours in mothers and children in rural Malawi (MaiMwana): a factorial, cluster- randomised controlled trial. Lancet. 2013;381:1721-35. Medline:23683639 doi:10.1016/S0140-6736(12)61959-X

64 Lassi ZS, Bhutta ZA. Community-based intervention packages for reducing maternal and neonatal morbidity and mortality and improving neonatal outcomes. Cochrane Database Syst Rev. 2015;11:CD007754. Medline:25803792 doi:10.1002/14651858. CD007754.pub3

65 Prost A, Colbourn T, Seward N, Azad K, Coomarasamy A, Copas A, et al. Women's groups practising participatory learning and action to improve maternal and newborn health in low-resource settings: a systematic review and meta-analysis. Lancet. 2013;381:1736-46. Medline:23683640 doi:10.1016/S0140-6736(13)60685-6

66 Soubeiga D, Gauvin L, Hatem MA, Johri M. Birth Preparedness and Complication Readiness (BPCR) interventions to reduce maternal and neonatal mortality in developing countries: systematic review and meta-analysis. BMC Pregnancy Childbirth. 2014;14:129. Medline:24708719 doi:10.1186/1471-2393-14-129 
67 Prost A, Colbourn T, Tripathy P, Osrin D, Costello A. Analyses confirm effect of women's groups on maternal and newborn deaths. Lancet. 2013;381:e15. Medline:23683648 doi:10.1016/S0140-6736(13)61082-X

68 Wang C, Wei Y, Zhang X, Zhang Y, Xu Q, Sun Y, et al. A randomized clinical trial of exercise during pregnancy to prevent gestational diabetes mellitus and improve pregnancy outcome in overweight and obese pregnant women. Am J Obstet Gynecol. 2017;216:340-51. Medline:28161306 doi:10.1016/j.ajog.2017.01.037

69 Wang C, Zhu W, Wei Y, Feng H, Su R, Yang H. Exercise intervention during pregnancy can be used to manage weight gain and improve pregnancy outcomes in women with gestational diabetes mellitus. BMC Pregnancy Childbirth. 2015;15:255. Medline:26459271 doi:10.1186/s12884-015-0682-1

70 Alexander DA, Northcross A, Karrison T, Morhasson-Bello O, Wilson N, Atalabi OM, et al. Pregnancy outcomes and ethanol cook stove intervention: A randomized-controlled trial in Ibadan, Nigeria. Environ Int. 2018;111:152-63. Medline:29216559 doi:10.1016/j.envint.2017.11.021

71 Muhindo MK, Kakuru A, Natureeba P, Awori P, Olwoch P, Ategeka J, et al. Reductions in malaria in pregnancy and adverse birth outcomes following indoor residual spraying of insecticide in Uganda. Malar J. 2016;15:437. Medline:27566109 doi:10.1186/ s12936-016-1489-x

72 Orobaton N, Austin AM, Abegunde D, Ibrahim M, Mohammed Z, Abdul-Azeez J, et al. Scaling-up the use of sulfadoxine-pyrimethamine for the preventive treatment of malaria in pregnancy: results and lessons on scalability, costs and programme impact from three local government areas in Sokoto State, Nigeria. Malar J. 2016;15:533. Medline:27814763 doi:10.1186/ s12936-016-1578-x

73 Roh ME, Shiboski S, Natureeba P, Kakuru A, Muhindo M, Ochieng T, et al. Protective Effect of Indoor Residual Spraying of Insecticide on Preterm Birth Among Pregnant Women With HIV Infection in Uganda: A Secondary Data Analysis. J Infect Dis. 2017;216:1541-9. Medline:29029337 doi:10.1093/infdis/jix533

74 Scott S, D’Alessandro U, Kendall L, Bradley J, Bojang K, Correa S, et al. Community-based malaria screening and treatment for pregnant women receiving standard intermittent preventive treatment with sulfadoxine-pyrimethamine: A multicenter (the gambia, burkina faso, and benin) cluster-randomized controlled trial. Clin Infect Dis. 2019;68:586-96. Medline:29961848

75 Unger HW, Ome-kaius M, Wangnapi RA, Umbers AJ, Hanieh S, Sn C, et al. Sulphadoxine-pyrimethamine plus azithromycin for the prevention of low birthweight in Papua New Guinea: a randomised controlled trial. BMC Med. 2015;13:9. Medline:25591391 doi:10.1186/s12916-014-0258-3

76 Salam RA, Maredia H, Das JK, Lassi ZS, Bhutta ZA. Community-based interventions for the prevention and control of helmintic neglected tropical diseases. Infect Dis Poverty. 2014:3:23. Medline:25114793 doi:10.1186/2049-9957-3-23

77 Maaløe N, Housseine N, Meguid T, Nielsen BB, Jensen AKG, Khamis RS, et al. Effect of locally tailored labour management guidelines on intrahospital stillbirths and birth asphyxia at the referral hospital of Zanzibar: a quasi-experimental pre-post study (The PartoMa study). BJOG. 2018;125:235-45. Medline:28892306 doi:10.1111/1471-0528.14933

78 Mgaya AH, Kidanto HL, Nystrom L, Essen B. Improving Standards of Care in Obstructed Labour: A Criteria-Based Audit at a Referral Hospital in a Low-Resource Setting in Tanzania. PLoS One. 2016;11:e0166619. Medline:27893765 doi:10.1371/ journal.pone.0166619

79 Okonofua FE, Ogu RN, Fabamwo AO, Ujah IO, Chama CM, Archibong EI, et al. Training health workers for magnesium sulfate use reduces case fatality from eclampsia: results from a multicenter trial. Acta Obstet Gynecol Scand. 2013;92:716-20. Medline:23550632 doi:10.1111/aogs.12135

80 Asare EV, Olayemi E, Boafor T, Dei-Adomakoh Y, Mensah E, Ghansah H, et al. Implementation of multidisciplinary care reduces maternal mortality in women with sickle cell disease living in low-resource setting. Am J Hematol. 2017;92:872-8. Medline:28512745 doi:10.1002/ajh.24790

81 Byaruhanga R, Bassani DG, Jagau A, Muwanguzi P, Montgomery AL, Lawn J. Use of wind-up fetal Doppler versus Pinard for fetal heart rate intermittent monitoring in labour: a randomised clinical trial. BMJ Open. 2015;5:e006867. Medline:25636792 doi:10.1136/bmjopen-2014-006867

82 Ngwenya S. Reducing fresh full term intrapartum stillbirths through leadership and accountability in a low-resource setting, Mpilo Central Hospital, Bulawayo, Zimbabwe. BMC Res Notes. 2017;10:246. Medline:28683767 doi:10.1186/s13104-0172567-z

83 Srofenyoh E, Ivester T, Engmann C, Olufolabi A, Bookman L, Owen M. Advancing obstetric and neonatal care in a regional hospital in Ghana via continuous quality improvement. Int J Gynaecol Obstet. 2012;116:17-21. Medline:22040863 doi:10.1016/j. ijgo.2011.08.010

84 Mgaya AH, Litorp H, Kidanto HL, Nystrom L, Essen B. Criteria-based audit to improve quality of care of foetal distress: standardising obstetric care at a national referral hospital in a low resource setting, Tanzania. BMC Pregnancy Childbirth. 2016;16:343. Medline:27825311 doi:10.1186/s12884-016-1137-z

85 Chomba E, Carlo WA, Goudar SS, Jehan I, Tshefu A, Garces A, et al. Effects of Essential Newborn Care Training on Fresh Stillbirths and Early Neonatal Deaths by Maternal Education. Neonatology. 2017;111:61-7. Medline:27544512 doi:10.1159/000447421

86 Gomez PP, Nelson AR, Asiedu A, Addo E, Agbodza D, Allen C, et al. Accelerating newborn survival in Ghana through a lowdose, high-frequency health worker training approach: A cluster randomized trial. BMC Pregnancy Childbirth. 2018;18:72. Medline:29566659 doi:10.1186/s12884-018-1705-5

87 Chinkhumba J, De Allegri M, Muula AS, Robberstad B. Maternal and perinatal mortality by place of delivery in sub-Saharan Africa: a meta-analysis of population-based cohort studies. BMC Public Health. 2014;14:1014. Medline:25263746 doi: 10.1186/1471-2458-14-1014

88 Day LT, Hruschka D, Mussell F, Jeffers E, Saha SL, Alam S. Perinatal mortality associated with use of uterotonics outside of Comprehensive Emergency Obstetric and Neonatal Care: a cross-sectional study. Reprod Health. 2016;13:129. Medline:27716260 doi:10.1186/s12978-016-0241-x 
89 Ganchimeg T, Nagata C, Vogel JP, Morisaki N, Pileggi-Castro C, Ortiz-Panozo E, et al. Optimal Timing of Delivery among LowRisk Women with Prior Caesarean Section: A Secondary Analysis of the WHO Multicountry Survey on Maternal and Newborn Health. PLoS One. 2016;11:e0149091. Medline:26866368 doi:10.1371/journal.pone.0149091

90 Godlonton S, Okeke EN. Does a ban on informal health providers save lives? Evidence from Malawi. J Dev Econ. 2016;118:11232. Medline:26681821 doi:10.1016/j.jdeveco.2015.09.001

91 Goudar SS, Goco N, Somannavar MS, Vernekar SS, Mallapur AA, Moore JL, et al. Institutional deliveries and perinatal and neonatal mortality in Southern and Central India. Reprod Health. 2015;12 Suppl 2:S13. Medline:26063586 doi:10.1186/17424755-12-S2-S13

92 Kayiga H, Lester F, Amuge PM, Byamugisha J, Autry AM. Impact of mode of delivery on pregnancy outcomes in women with premature rupture of membranes after 28 weeks of gestation in a low-resource setting: A prospective cohort study. PLoS One. 2018;13:e0190388. Medline:29320516 doi:10.1371/journal.pone.0190388

93 Khanam R, Baqui H, Moin MI, Harrison M, Quaiyum A, Saha K, et al. Can facility delivery reduce the risk of intrapartum complications-related perinatal mortality? Findings from a cohort study. J Glob Health. 2018;8:010408. Medline:29564085 doi:10.7189/jogh.08.010408

94 Chagomerana MB, Miller WC, Pence BW, Hosseinipour MC, Hoffman IF, Flick RJ, et al. PMTCT Option B+ Does Not Increase Preterm Birth Risk and May Prevent Extreme Prematurity: A Retrospective Cohort Study in Malawi. J Acquir Immune Defic Syndr. 2017;74:367-74. Medline:27875363 doi:10.1097/QAI.0000000000001253

95 Rempis EM, Schnack A, Decker S, Braun V, Rubaihayo J, Tumwesigye NM, et al. Option B + for prevention of vertical HIV transmission has no influence on adverse birth outcomes in a cross-sectional cohort in Western Uganda. BMC Pregnancy Childbirth. 2017;17:82. Medline:28270119 doi:10.1186/s12884-017-1263-2

96 Lancaster KE, Kwok C, Rinaldi A, Byamugisha J, Nyamapfeni P, Salata RA, et al. Incident pregnancy and pregnancy outcomes among HIV-infected women in Uganda and Zimbabwe. Int J Gynaecol Obstet. 2015;131:255-9. Medline:26387468 doi:10.1016/j.ijgo.2015.06.035

97 Westen EHMN, Kolk PR, Velzen CLVAN, Unkels R, Mmuni NS, Hamisi AD, et al. Single-dose compared with multiple day antibiotic prophylaxis for cesarean section in low-resource settings, a randomized controlled, noninferiority trial. Acta Obstet Gynecol Scand. 2015;94:43-9. Medline:25263498 doi:10.1111/aogs.12517

98 Brizot ML, Hernandez W, Liao AW, Bittar RE, Francisco RPV, Krebs VLJ, et al. Vaginal progesterone for the prevention of preterm birth in twin gestations: a randomized. Am J Obstet Gynecol. 2015;213:82.e1-9. Medline:25731690 doi:10.1016/j. ajog.2015.02.021

99 Haghighi L, Rashidi M, Najmi Z, Homam H, Hashemi N. Comparison of intramuscular progesterone with oral nifedipine for treating threatened preterm labor: A randomized controlled trial. Med J Islam Repub Iran. 2017;31:56. Medline:29445685 doi:10.14196/mjiri.31.56

100 Jiang H, Xiang X, Su Y, Peng J, Zhu X, Wang J, et al. Use of antiseptic mouthrinse during pregnancy and pregnancy outcomes: a randomised controlled clinical trial in rural China. BJOG. 2016;123(3, SI):39-47. Medline:27627596 doi:10.1111/14710528.14010

101 Edmond KM, Newton S, Shannon C, O'Leary M, Hurt L, Thomas G, et al. Effect of early neonatal vitamin A supplementation on mortality during infancy in Ghana (Neovita): A randomised, double-blind, placebo-controlled trial. Lancet. 2015;385:1315-23. Medline:25499545 doi:10.1016/S0140-6736(14)60880-1

102 Deshpande G, Jape G, Rao S, Patole S. Benefits of probiotics in preterm neonates in low-income and medium-income countries: a systematic review of randomised controlled trials. BMJ Open. 2017;7:e017638. Medline:29222137 doi:10.1136/bmjopen-2017-017638

103 Panigrahi P, Parida S, Nanda NC, Satpathy R, Pradhan L, Chandel DS, et al. A randomized synbiotic trial to prevent sepsis among infants in rural India. Nature. 2017;548:407-12. Medline:28813414 doi:10.1038/nature23480

104 Patel S, Chaudhari M, Kadam S, Rao S, Patole S. Standardized feeding and probiotic supplementation for reducing necrotizing enterocolitis in preterm infants in a resource limited set up. Eur J Clin Nutr. 2018;72:281-7. Medline:29255185 doi:10.1038/ s41430-017-0040-7

105 Santana RNS, Santos VS, Ribeiro-Júnior RF, Freire MS, Menezes MAS, Cipolotti R, et al. Use of ranitidine is associated with infections in newborns hospitalized in a neonatal intensive care unit: A cohort study. BMC Infect Dis. 2017;17:1375. Medline:28558748 doi:10.1186/s12879-017-2482-x

106 Serce O, Benzer D, Gursoy T, Karatekin G, Ovali F. Efficacy of saccharomyces boulardii on necrotizing enterocolitis or sepsis in very low birth weight infants: A randomised controlled trial. Early Hum Dev. 2013;89:1033-6. Medline:24041815 doi:10.1016/j.earlhumdev.2013.08.013

107 Soofi S, Ariff S, Sadiq K, Habib A, Bhatti Z, Ahmad I, et al. Evaluation of the uptake and impact of neonatal Vitamin A supplementation delivered through the Lady Health Worker programme on neonatal and infant morbidity and mortality in rural Pakistan: An effectiveness trial. Arch Dis Child. 2017;102:216-23. Medline:27471856 doi:10.1136/archdischild-2016-310542

108 Tali S, Kabra N, Ahmed J, Dash S, Balasubramanian H, Avasthi B, et al. Effect of feeding scheduleon time toreach full feeds in ELBW and VLBW neonates: a randomized trial. Perinatology. 2016;17:95-102.

109 Debes AK, Kohli A, Walker N, Edmond K, Mullany LC. Time to initiation of breastfeeding and neonatal mortality and morbidity: A systematic review. BMC Public Health. 2013;13 SUPPL.3:S19. Medline:24564770 doi:10.1186/1471-2458-13-S3-S19

110 English R, Peer N, Honikman S, Tugendhaft A, Hofman KJ. 'First 1000 days' health interventions in low-and middle-income countries: alignment of South African policies with high-quality evidence. Glob Health Action. 2017;10:1340396. Medline:28715934 doi:10.1080/16549716.2017.1340396 
111 Khan J, Vesel L, Bahl R, Martines J. Timing of Breastfeeding Initiation and Exclusivity of Breastfeeding During the First Month of Life: Effects on Neonatal Mortality and Morbidity - A Systematic Review and Meta-analysis. Matern Child Health J. 2015;19:468-79. Medline:24894730 doi:10.1007/s10995-014-1526-8

112 Banupriya N, Vishnu Bhat B, Benet BD, Sridhar MG, Parija SC. Efficacy of zinc supplementation on serum calprotectin, inflammatory cytokines and outcome in neonatal sepsis - a randomized controlled trial. J Matern Fetal Neonatal Med. 2017;30:162731. Medline:27491377 doi:10.1080/14767058.2016.1220524

113 Güney-Varal I, Köksal N, Özkan H, Bağcl O, Doğan P. The effect of early administration of combined multi-strain and multi-species probiotics on gastrointestinal morbidities and mortality in preterm infants: A randomized controlled trial in a tertiary care unit. Turk J Pediatr. 2017;59:13-9. Medline:29168358 doi:10.24953/turkjped.2017.01.003

114 Dilli D, Aydin B, Fettah ND, Ozyazici E, Beken S, Zenciroglu A, et al. The propre-save study: effects of probiotics and prebiotics alone or combined on necrotizing enterocolitis in very low birth weight infants. J Pediatr. 2015;166:545-51.e1. Medline:25596096 doi:10.1016/j.jpeds.2014.12.004

115 Oncel MY, Sari FN, Arayici S, Guzoglu N, Erdeve O, Uras N, et al. Lactobacillus Reuteri for the prevention of necrotising enterocolitis in very low birthweight infants: a randomised controlled trial. Arch Dis Child Fetal Neonatal Ed. 2014;99:F110-5. Medline:24309022 doi:10.1136/archdischild-2013-304745

116 Fernández-Carrocera LA, Solis-Herrera A, Cabanillas-Ayon M, Gallardo-Sarmiento RB, Garcia-Perez CS, Montano-Rodriguez $\mathrm{R}$, et al. Double-blind, randomised clinical assay to evaluate the efficacy of probiotics in preterm newborns weighing less than $1500 \mathrm{~g}$ in the prevention of necrotising enterocolitis. Arch Dis Child Fetal Neonatal Ed. 2013;98:F5-9. Medline:22556209 doi:10.1136/archdischild-2011-300435

117 Kaur G, Gathwala G. Efficacy of bovine lactoferrin supplementation in preventing late-onset sepsis in low birth weight neonates: A randomized placebo-Controlled clinical trial. J Trop Pediatr. 2015;61:370-6. Medline:26224129 doi:10.1093/ tropej/fmv044

118 Lund N, Biering-Sørensen S, Andersen A, Monteiro I, Camala L, Jørgensen MJ, et al. Neonatal vitamin A supplementation associated with a cluster of deaths and poor early growth in a randomised trial among low-birth-weight boys of vitamin A versus oral polio vaccine at birth. BMC Pediatr. 2014;14:214. Medline:25163399 doi:10.1186/1471-2431-14-214

119 Mahallei M, Gharehbaghi MM, Majidzadeh L, Hazhir N. Comparing the Efficacy of High and Low Doses of Vitamin A in Prevention of Bronchopulmonary Dysplasia. Int J Pediatr. 2016;4:1919-25.

120 Masanja H, Smith ER, Muhihi A, Briegleb C, Mshamu S, Ruben J, et al. Effect of neonatal vitamin A supplementation on mortality in infants in Tanzania (Neovita): A randomised, double-blind, placebo-controlled trial. Lancet. 2015;385:1324-32. Medline:25499543 doi:10.1016/S0140-6736(14)61731-1

121 Mazumder S, Taneja S, Bhatia K, Yoshida S, Kaur J, Dube B, et al. Efficacy of early neonatal supplementation with vitamin A to reduce mortality in infancy in Haryana, India (Neovita): A randomised, double-blind, placebo-controlled trial. Lancet. 2015;385:1333-42. Medline:25499546 doi:10.1016/S0140-6736(14)60891-6

122 Nandhini LP, Biswal N, Adhisivam B, Mandal J, Bhatb V, Mathai B. Synbiotics for decreasing incidence of necrotizing enterocolitis among preterm neonates - A randomized controlled trial. J Matern Fetal Neonatal Med. 2016;29:821-5. Medline:25754214 doi:10.3109/14767058.2015.1019854

123 Van Niekerk E, Nel DG, Blaauw R, Kirsten GF. Probiotics reduce necrotizing enterocolitis severity in HIV-exposed premature infants. J Trop Pediatr. 2015;61:155-64. Medline:25724213 doi:10.1093/tropej/fmv004

124 Haider BA, Sharma R, Bhutta ZA. Neonatal vitamin A supplementation for the prevention of mortality and morbidity in term neonates in low and middle income countries. Cochrane Database Syst Rev. 2017;2:CD006980. Medline:28234402 doi:10.1002/14651858.CD006980.pub3

125 Lunze K, Bloom DE, Jamison DT, Hamer DH. The global burden of neonatal hypothermia: systematic review of a major challenge for newborn survival. BMC Med. 2013;11:24. Medline:23369256 doi:10.1186/1741-7015-11-24

126 Mullany LC, Katz J, Khatry SK, LeClerq SC, Darmstadt GL, Tielsch JM. Risk of mortality associated with neonatal hypothermia in southern Nepal. Arch Pediatr Adolesc Med. 2010;164:650-6. Medline:20603466 doi:10.1001/archpediatrics.2010.103

127 Jayaraman D, Mukhopadhyay K, Bhalla AK, Dhaliwal LK. Randomized Controlled Trial on Effect of Intermittent Early Versus Late Kangaroo Mother Care on Human Milk Feeding in Low-Birth-Weight Neonates. J Hum Lact. 2017;33:533-9. Medline:28152330 doi:10.1177/0890334416685072

128 Leng H, Wang H, Lin B, Cheng G, Wang L. Reducing Transitional Hypothermia in Outborn Very Low Birth Weight Infants. Neonatology. 2016;109:31-6. Medline:26485388 doi:10.1159/000438743

129 Leadford AE, Warren JB, Manasyan A, Chomba E, Salas AA, Schelonka R, et al. Plastic Bags for Prevention of Hypothermia in Preterm and Low Birth Weight Infants. Pediatrics. 2013;132:e128-34. Medline:23733796 doi:10.1542/peds.2012-2030

130 Massawe A, Kidanto HL, Moshiro R, Majaliwa E, Chacha F, Shayo A, et al. A care bundle including antenatal corticosteroids reduces preterm infant mortality in Tanzania a low resource country. PLoS One. 2018;13:e0193146. Medline:29513706 doi:10.1371/journal.pone.0193146

131 Roy SS, Mahapatra R, Rath S, Bajpai A, Singh V, Rath S, et al. Improved neonatal survival after participatory learning and action with women's groups: A prospective study in rural eastern India. Bull World Health Organ. 2013;91:426-433B. Medline:24052679 doi:10.2471/BLT.12.105171

132 Conde-Agudelo A, Diaz-Rossello JL. Kangaroo mother care to reduce morbidity and mortality in low birthweight infants. Cochrane Database Syst Rev. 2014;(4):CD002771. Medline:24752403 doi:10.1002/14651858.CD002771.pub3

133 Afjeh SA, Sabzehei M, Fahimzad S, Shiva F, Shamshiri A, Esmaili F. Antibiotic Therapy for Very Low Birth Weigh Newborns in NICU. Iran J Pediatr. 2016;26:e2612. Medline:27307961 
134 Erdemir A, Kahramaner Z, Yuksel Y, Cosar H, Turkoglu E, Sutcuoglu S, et al. The effect of topical ointment on neonatal sepsis in preterm infants. J Matern Fetal Neonatal Med. 2015;28:33-6. Medline:24588277 doi:10.3109/14767058.2014.900037

135 Li J, Wu J, Du L, Hu Y, Yang X, Mu D, et al. Different antibiotic strategies in transient tachypnea of the newborn: an ambispective cohort study. Eur J Pediatr. 2015;174:1217-23. Medline:25833763 doi:10.1007/s00431-015-2526-4

136 Salam RA, Das JK, Darmstadt GL, Bhutta ZA. Emollient therapy for preterm newborn infants evidence from the developing world. BMC Public Health. 2013;13:S31. Medline:24564550 doi:10.1186/1471-2458-13-S3-S31

137 Sankar MJ, Paul VK. Efficacy and safety of whole body skin cleansing with chlorhexidine in neonates-a systemic review. Pediatr Infect Dis J. 2013;32:e227-34. Medline:23340558 doi:10.1097/INF.0b013e31828693f6

138 Sazawal S, Dhingra U, Ali SM, Dutta A, Deb S, Ame SM, et al. Efficacy of chlorhexidine application to umbilical cord on neonatal mortality in Pemba, Tanzania: a community-based randomised controlled trial. Lancet Glob Health. 2016;4:e837-44. Medline:27693438 doi:10.1016/S2214-109X(16)30223-6

139 Schmidt S, Bounnack S, Hoehn T. Neonatal mortality and morbidity in the post-implementation period of a neonatal teaching program in provincial hospitals in Laos. Public Health. 2018;154:123-9. Medline:29232564 doi:10.1016/j.puhe.2017.10.021

140 Shabaan AE, Nour I, Elsayed Eldegla H, Nasef N, Shouman B, Abdel-Hady H. Conventional Versus Prolonged Infusion of Meropenem in Neonates With Gram-negative Late-onset Sepsis: A Randomized Controlled Trial. Pediatr Infect Dis J. 2017;36:358-63. Medline:27918382 doi:10.1097/INF.0000000000001445

141 Soofi S, Cousens S, Turab A, Wasan Y, Mohammed S, Ariff S, et al. Effect of provision of home-based curative health services by public sector health-care providers on neonatal survival: a community-based cluster-randomised trial in rural Pakistan. Lancet Glob Health. 2017;5:e796-806. Medline:28716351 doi:10.1016/S2214-109X(17)30248-6

142 Zhou Q, Lee SK, Jiang SY, Chen C, Kamaluddeen M, Hu XJ, et al. Efficacy of an infection control program in reducing ventilator-associated pneumonia in a Chinese neonatal intensive care unit. Am J Infect Control. 2013;41:1059-64. Medline:24041863 doi:10.1016/j.ajic.2013.06.007

143 Cleminson J, McGuire W. Topical emollient for preventing infection in preterm infants. Cochrane Database Syst Rev. 2016;1:CD001150. Medline:26824786 doi:10.1002/14651858.CD001150.pub3

144 Hosseini M, Mahallei M, Mahramuz B, Behtari M, Alemi P, Oskuoee S, et al. Impact of empirical antibiotic treatment duration on short-term prognosis of very low birth weight newborns. Crescent J Med Biol Sci. 2017;4:59-63.

145 Pinto MCFG, Bueno AC, Vieira AA. Implementation of a protocol proposed by the Brazilian National Health Surveillance Agency for antibiotic use in very low birth weight infants. J Pediatr (Rio J). 2013;89:450-5. Medline:23870480 doi:10.1016/j. jped.2013.01.009

146 Salam RA, Darmstadt GL, Bhutta ZA. Effect of emollient therapy on clinical outcomes in preterm neonates in Pakistan: a randomised controlled trial. Arch Dis Child Fetal Neonatal Ed. 2015;100:F210-5. Medline:25637007 doi:10.1136/archdischild-2014-307157

147 Semrau KEA, Herlihy J, Grogan C, Musokotwane K, Yeboah-antwi K, Mbewe R, et al. Effectiveness of 4\% chlorhexidine umbilical cord care on neonatal mortality in Southern Province, Zambia (ZamCAT): a cluster-randomised controlled trial. Lancet Glob Health. 2016;4:e827-36. Medline:27693439 doi:10.1016/S2214-109X(16)30215-7

148 Bhutta ZA, Das JK, Rizvi A, Gaff MF, Walker N, Horton S, et al. Evidence-based interventions for improvement of maternal and child nutrition: what can be done and at what cost? Lancet. 2013;382:452-77. Medline:23746776 doi:10.1016/S01406736(13)60996-4

149 Cleminson J, Mcguire W. Topical emollient for prevention of infection in preterm infants: a systematic review. Lancet. 2015;385:S31. Medline:26312853 doi:10.1016/S0140-6736(15)60346-4

150 Ali E, Abdel Wahed M, Alsalami Z, Abouseif H, Gottschalk T, Rabbani R, et al. New modalities to deliver surfactant in premature infants: a systematic review and meta-analysis. J Matern Fetal Neonatal Med. 2016;29:3519-24. Medline:26864884 doi:10.3109/14767058.2015.1136997

151 Boo N-Y, Cheah IG-S, Neoh S-H, Chee S-C, Registry MNN. Impact and Challenges of Early Continuous Positive Airway Pressure Therapy for Very Low Birth Weight Neonates in a Developing Country. Neonatology. 2016;110:116-24. Medline:27074004 doi:10.1159/000444316

152 Martin S, Duke T, Davis P. Efficacy and safety of bubble CPAP in neonatal care in low and middle income countries: a systematic review. Arch Dis Child Fetal Neonatal Ed. 2014;99:F495-504. Medline:25085942 doi:10.1136/archdischild-2013-305519

153 Mazmanyan P, Mellor K, Dore CJ, Modi N. A randomised controlled trial of flow driver and bubble continuous positive airway pressure in preterm infants in a resource-limited setting. Arch Dis Child Fetal Neonatal Ed. 2016;101:F16-20. Medline:26271753 doi:10.1136/archdischild-2015-308464

154 Myhre J, Immaculate M, Okeyo B, Anand M, Omoding A, Myhre L, et al. Effect of treatment of premature infants with respiratory distress using low-cost bubble CPAP in a rural African hospital. J Trop Pediatr. 2016;62:385-9. Medline:27118822 doi:10.1093/tropej/fmw023

155 Nahimana E, Ngendahayo M, Magge H, Odhiambo J, Amoroso CL, Muhirwa E, et al. Bubble CPAP to support preterm infants in rural Rwanda: a retrospective cohort study. BMC Pediatr. 2015;15:135. Medline:26403679 doi:10.1186/s12887015-0449-x

156 Niknafs P, Faghani A, Afjeh SA, Moradinazer M, Bahman-Bijari B. Management of neonatal respiratory distress syndrome employing ACoRN respiratory sequence protocol versus early nasal continuous positive airway pressure protocol. Iran J Pediatr. 2014:24:57-63. Medline:25793046

157 Ntigurirwa P, Mellor K, Langer D, Evans M, Robertson E, Tuyisenge L, et al. A health partnership to reduce neonatal mortality in four hospitals in Rwanda. Global Health. 2017;13:28. Medline:28569202 doi:10.1186/s12992-017-0252-6 
158 Rebello CM, Precioso AR, Mascaretti RS. A multicenter, randomized, double-blind trial of a new porcine surfactant in premature infants with respiratory distress syndrome. Einstein (Sao Paulo). 2014;12:397-404. Medline:25628188 doi:10.1590/ S1679-45082014AO3095

159 Sankar MJ, Gupta N, Jain K, Agarwal R, Paul VK. Efficacy and safety of surfactant replacement therapy for preterm neonates with respiratory distress syndrome in low- and middle-income countries: a systematic review. J Perinatol. 2016;36 Suppl 1:S36-48. Medline:27109091 doi:10.1038/jp.2016.31

160 Say B, Kanmaz Kutman HG, Oguz SS, Oncel MY, Arayici S, Canpolat FE, et al. Binasal Prong versus Nasal Mask for Applying CPAP to Preterm Infants: A Randomized Controlled Trial. Neonatology. 2016;109:258-64. Medline:26859512 doi:10.1159/000443263

161 Thukral A, Sankar MJ, Chandrasekaran A, Agarwal R, Paul VK. Efficacy and safety of CPAP in low- and middle-income countries. J Perinatol. 2016;36 Suppl 1:S21-8. Medline:27109089 doi:10.1038/jp.2016.29

162 Ceylan A, Gezer S, Demir N, Tuncer O, Peker E, Kirimi E. The importance of administration of early surfactant and nasal continuous positive airway pressure in newborns with respiratory distress syndrome. Turk Pediatri Ars. 2014;49:192-7. Medline:26078662 doi:10.5152/tpa.2014.1624

163 Zubizarreta JR, Lorch SA, Marshall G, D’apremont I, Tapia JL. Effect of prophylactic CPAP in very low birth weight infants in South America. J Perinatol. 2016;36:629-34. Medline:27054844 doi:10.1038/jp.2016.56

164 Guinsburg R, de Almeida MFB, de Castro JS, Goncalves-Ferri WA, Marques PF, Caldas JPS, et al. T-piece versus self-inflating bag ventilation in preterm neonates at birth. Arch Dis Child Fetal Neonatal Ed. 2018;103:F49-55. Medline:28663283 doi:10.1136/archdischild-2016-312360

165 Kanmaz HG, Erdeve O, Canpolat FE, Mutlu B, Dilmen U. Surfactant administration via thin catheter during spontaneous breathing: randomized controlled trial. Pediatrics. 2013;131:e502-9. Medline:23359581 doi:10.1542/peds.2012-0603

166 Rezzonico R, Caccamo LM, Manfredini V, Cartabia M, Sanchez N, Paredes Z, et al. Impact of the systematic introduction of low-cost bubble nasal CPAP in a NICU of a developing country: a prospective pre- and post-intervention study. BMC Pediatr. 2015;15:26. Medline:25885437 doi:10.1186/s12887-015-0338-3

167 Crivceanscaia L, Avasiloaiei A, Moscalu M, Stamatin M. Short-Term Predictive Factors for the Outcome of Preterm Infants Depending on the Method of Respiratory Support. Medical-Surgical Journal-Revista Medico-Chirurgicala. 2017;121:681-8.

168 Daga S, Daga A, Mhatre S, Ghane V. Enhancing neonatal survival: what can we do today? J Perinatol. 2016;36:681-4. Medline:27054840 doi:10.1038/jp.2016.51

169 Dilmen U, Özdemir R, Tatar Aksoy H, Uras N, Demirel N, Kirimi E, et al. Early regular versus late selective poractant treatment in preterm infants born between 25 and 30 gestational weeks: A prospective randomized multicenter study. J Matern Fetal Neonatal Med. 2014;27:411-5. Medline:23795582 doi:10.3109/14767058.2013.818120

170 Gonçalves-Ferri WA, Martinez FE, Caldas JPS, Marba STM, Fekete S, Rugolo L, et al. Application of continuous positive airway pressure in the delivery room: a multicenter randomized clinical trial. Braz J Med Biol Res. 2014;47:259-64. Medline:24554040 doi:10.1590/1414-431X20133278

171 Kawaza K, Machen HE, Brown J, Mwanza Z, Iniguez S, Gest A, et al. Efficacy of a Low-Cost Bubble CPAP System in Treatment of Respiratory Distress in a Neonatal Ward in Malawi. PLoS One. 2014;9:e86327. Medline:24489715 doi:10.1371/ journal.pone.0086327

172 Kong X, Cui Q, Hu Y, Huang W, Ju R, Li W, et al. Bovine surfactant replacement therapy in neonates of less than 32 weeks' gestation: A multicenter controlled trial of prophylaxis versus early treatment in China - A pilot study. Pediatr Neonatol. 2016;57:19-26. Medline:26059103 doi:10.1016/j.pedneo.2015.03.007

173 Kumar MS, Najih M, Bhat YR, Jayashree P, Lewis LES, Kamath A, et al. Prophylactic methylxanthines for preventing extubation failure in the preterm neonates with the gestational age of $\leq 30$ weeks: A randomized controlled trial. Iran J Neonatol. 2017:8:11-8.

174 Carns J, Kawaza K, Quinn MK, Miao Y, Guerra R, Molyneux E, et al. Impact of hypothermia on implementation of CPAP for neonatal respiratory distress syndrome in a low-resource setting. PLoS One. 2018;13:e0194144. Medline:29543861 doi:10.1371/journal.pone.0194144

175 Soll RF. Synthetic surfactant for respiratory distress syndrome in preterm infants. Cochrane Database Syst Rev. 2000;2:CD001149. Medline:10796417

176 Lassi ZS, Haider BA, Bhutta ZA. Community-based intervention packages for reducing maternal and neonatal morbidity and mortality and improving neonatal outcomes. Cochrane Database Syst Rev. 2010;11:CD007754. Medline:21069697 doi:10.1002/14651858.CD007754.pub2

177 Boone P, Eble A, Elbourne D, Frost C, Jayanty C, Lakshminarayana R, et al. Community health promotion and medical provision for neonatal health - CHAMPION cluster randomised trial in Nagarkurnool district, Telangana (formerly Andhra Pradesh), India. PLoS Med. 2017;14:e1002324. Medline:28678849 doi:10.1371/journal.pmed.1002324

178 Colbourn T, Nambiar B, Bondo A, Makwenda C, Tsetekani E, Makonda-Ridley A, et al. Effects of quality improvement in health facilities and community mobilization through women's groups on maternal, neonatal and perinatal mortality in three districts of Malawi: MaiKhanda, a cluster randomized controlled effectiveness trial. Int Health. 2013;5:180-95. Medline:24030269 doi:10.1093/inthealth/iht011

179 Persson LÅ, Nga NT, Målqvist M, Thi Phuong Hoa D, Eriksson L, Wallin L, et al. Effect of Facilitation of Local Maternal-and-Newborn Stakeholder Groups on Neonatal Mortality: Cluster-Randomized Controlled Trial. PLoS Med. 2013;10:e1001445. Medline:23690755 doi:10.1371/journal.pmed.1001445

180 Singh K, Speizer I, Handa S, Boadu RO, Atinbire S, Barker PM, et al. Impact evaluation of a quality improvement intervention on maternal and child health outcomes in Northern Ghana: early assessment of a national scale-up project. Int J Qual Health Care. 2013;25:477-87. Medline:23925506 doi:10.1093/intqhc/mzt054 
181 Kirkwood BR, Manu A, ten Asbroek AHA, Soremekun S, Weobong B, Gyan T, et al. Effect of the Newhints home-visits intervention on neonatal mortality rate and care practices in Ghana: a cluster randomised controlled trial. Lancet. 2013;381:218492. Medline:23578528 doi:10.1016/S0140-6736(13)60095-1

182 Sadeck LSR, Leone CR, Procianoy RS, Guinsburg R, Marba STM, Martinez FE, et al. Effects of therapeutic approach on the neonatal evolution of very low birth weight infants with patent ductus arteriosus. J Pediatr (Rio J). 2014;90:616-23. Medline:25046256 doi:10.1016/j.jped.2014.04.010

183 Ohlsson A, Shah PS. Paracetamol (acetaminophen) for patent ductus arteriosus in preterm or low-birth-weight infants. Cochrane Database Syst Rev. 2018;4:CD010061. Medline:29624206 doi:10.1002/14651858.CD010061.pub3

184 Dempsey E, Pammi M, Ryan AC, Barrington KJ. Standardised formal resuscitation training programmes for reducing mortality and morbidity in newborn infants. Cochrane Database Syst Rev. 2015;9:CD009106. Medline:26337958 doi:10.1002/14651858.CD009106.pub2

185 Goudar SS, Somannavar M, Clark R, Lockyer JM, Revankar AP, Fidler HM, et al. Stillbirth and Newborn Mortality in India After Helping Babies Breathe Training. Pediatrics. 2013;131:e344-52. Medline:23339215 doi:10.1542/peds.2012-2112

186 Kc A, Wrammert J, Clark RB, Ewald U, Vitrakoti R, Chaudhary P, et al. Reducing Perinatal Mortality in Nepal Using Helping Babies Breathe. Pediatrics. 2016;137:e20150117. Medline:27225317 doi:10.1542/peds.2015-0117

187 Mduma E, Ersdal H, Svensen E, Kidanto H, Auestad B, Perlman J. Frequent brief on-site simulation training and reduction in 24-h neonatal mortality-An educational intervention study. Resuscitation. 2015;93:1-7. Medline:25957942 doi:10.1016/j. resuscitation.2015.04.019

188 Namazzi G, Waiswa P, Nakakeeto M, Nakibuuka VK, Namutamba S, Najjemba M, et al. Strengthening health facilities for maternal and newborn care: experiences from rural eastern Uganda. Glob Health Action. 2015;8:24271. Medline:25843496 doi:10.3402/gha.v8.24271

189 Opiyo N, English M. In-service training for health professionals to improve care of the seriously ill newborn or child in low and middle-income countries [Review]. Cochrane Database Syst Rev. 2010;4:CD007071. Medline:20393956 doi:10.1002/14651858.CD007071.pub2

190 Sousa S, Mielke JG. Does Resuscitation Training Reduce Neonatal Deaths in Low-Resource Communities? A Systematic Review of the Literature. Asia Pac J Public Health. 2015;27:690-704. Medline:26378066 doi:10.1177/1010539515603447

191 Turner C, Carrara V, Thein NAM, Win NCMM, Turner P, Bancone G, et al. Neonatal Intensive Care in a Karen Refugee Camp: A 4 Year Descriptive Study. PLoS One. 2013;8:e72721. Medline:23991145 doi:10.1371/journal.pone.0072721

192 Wrammert J, Kc A, Ewald U, Målqvist M. Improved postnatal care is needed to maintain gains in neonatal survival after the implementation of the Helping Babies Breathe initiative. Acta Paediatr. 2017;106:1280-5. Medline:28316097 doi:10.1111/ apa. 13835

193 Gilbert C, Darlow B, Zin A, Sivasubramaniam S, Shah S, Gianini N, et al. Educating Neonatal Nurses in Brazil: A Before-and-After Study with Interrupted Time Series Analysis. Neonatology. 2014;106:201-8. Medline:25012540 doi:10.1159/000362532

194 Bellad RM, Bang A, Carlo WA, McClure EM, Meleth S, Goco N, et al. A pre-post study of a multi-country scale up of resuscitation training of facility birth attendants: does Helping Babies Breathe training save lives? BMC Pregnancy Childbirth. 2016;16:222. Medline:27527831 doi:10.1186/s12884-016-0997-6

195 Pammi M, Dempsey M, Anthony C, Barrington K. Newborn Resuscitation Training Programmes Reduce Early Neonatal Mortality. Neonatology. 2016;110:210-24. Medline:27222260 doi:10.1159/000443875

196 Msemo G, Massawe A, Mmbando D, Rusibamayila N, Manji K, Kidanto HL, et al. Newborn Mortality and Fresh Stillbirth Rates in Tanzania After Helping Babies Breathe Training. Pediatrics. 2013;131:e353-60. Medline:23339223 doi:10.1542/ peds.2012-1795

197 Cavicchiolo ME, Lanzoni P, Wingi MO, Pizzol D, Daverio M, Da Dalt L, et al. Reduced neonatal mortality in a regional hospital in Mozambique linked to a Quality Improvement intervention. BMC Pregnancy Childbirth. 2016;16:366-6. Medline:27876013 doi:10.1186/s12884-016-1170-y

198 Harris C, Patel H, Corn O, Harris U, Munyagwa M, Greenough A. Neonatal Mortality in Western Uganda. Arch Dis Child. 2018;103 Suppl 1:A112.

199 Kakkad KM, Patel MS, Patel S, Kakkad K. Effect of "Janani Shishu Suraksha Karyakram" - a Government Health Beneficiary Scheme - on Admission Rate and Clinical Outcome in Nicu in a Tertiary Care Hospital. Natl J Community Med. 2014;5:11821.

200 Zonneveld R, Holband N, Bertolini A, Bardi F, Lissone NPA, Dijk PH, et al. Improved referral and survival of newborns after scaling up of intensive care in Suriname. BMC Pediatr. 2017;17:189. Medline:29137607 doi:10.1186/s12887-017-0941-6

201 Chola L, McGee S, Tugendhaft A, Buchmann E, Hofman K. Scaling Up Family Planning to Reduce Maternal and Child Mortality: The Potential Costs and Benefits of Modern Contraceptive Use in South Africa. PLoS One. 2015;10:e0130077. Medline:26076482 doi:10.1371/journal.pone.0130077

202 Blencowe H, Cousens S, Jassir FB, Say L, Chou D, Mathers C, et al. National, regional, and worldwide estimates of stillbirth rates in 2015, with trends from 2000: A systematic analysis. Lancet Glob Health. 2016;4:e98-108. Medline:26795602 doi:10.1016/S2214-109X(15)00275-2

203 Lassi ZS, Mansoor T, Salam RA, Das JK, Bhutta ZA. Essential pre-pregnancy and pregnancy interventions for improved maternal, newborn and child health. Reprod Health. 2014;11:S2. Medline:25178042 doi:10.1186/1742-4755-11-S1-S2

204 Bhutta ZA, Yakoob MY, Lawn JE, Rizvi A, Friberg IK, Weissman E, et al. Stillbirths: What difference can we make and at what cost? Lancet. 2011;377:1523-38. Medline:21496906 doi:10.1016/S0140-6736(10)62269-6

205 Geleto A, Chojenta C, Musa A, Loxton D. Barriers to access and utilization of emergency obstetric care at health facilities in sub-Saharan Africa: a systematic review of literature. Syst Rev. 2018;7:183-5. Medline:30424808 doi:10.1186/s13643-0180842-2 
206 Heidkamp R, Clermont A, Phillips E. Modeling the Impact of Nutrition Interventions on Birth Outcomes in the Lives Saved Tool (LiST). J Nutr. 2017;147:2188S-93S. Medline:28904112

207 World Health Organization \& UNICEF. Every newborn: An Action Plan to End Preventable Deaths. Geneva: WHO; 2014.

208 World Health Organization. Ongoing Research Project Overview: Immediate Kangaroo Mother Care (i-KMC). 2017. Available http://www.who.int/maternal_child_adolescent/research/who-mca-ikmc.pdf?ua=1. Accessed: 18 July 2018.

209 Rule AR, Maina E, Cheruiyot D, Mueri P, Simmons J, Kamath-Rayne B. Using quality improvement to decrease birth asphyxia rates after 'Helping Babies Breathe ' training in Kenya. Acta Paediatr. 2017;106:1666-73. Medline:28580692 doi:10.1111/ apa. 13940

210 Irimu G, Ogero M, Mbevi G, Agweyu A, Akech S, Julius T, et al. Approaching quality improvement at scale: a learning health system approach in Kenya. Arch Dis Child. 2018;103:1013-9. Medline:29514814 doi:10.1136/archdischild-2017-314348

211 World Health Organization. Standards for improving quality of maternal and newborn care in health facilities. Geneva: WHO; 2016.

212 English M, Karumbi J, Maina M, Aluvaala J, Gupta A, Zwarenstein M, et al. The need for pragmatic clinical trials in low and middle income settings - taking essential neonatal interventions delivered as part of inpatient care as an illustrative example. BMC Med. 2016;14:5. Medline:26782822 doi:10.1186/s12916-016-0556-z

213 Chen L, Evans T, Anand S, Boufford JI, Brown H, Chowdhury M, et al. Human resources for health: overcoming the crisis. Lancet. 2004;364:1984-90. Medline:15567015 doi:10.1016/S0140-6736(04)17482-5

214 Olsen L, Aisner D, McGinnis J. The Learning Healthcare System: Workshop Summary. Olsen L, Aisner D, McGinnis JM, editors. Washington (DC); 2007.

215 Tough AG, Lihoma P. Medical record keeping systems in Malawi: Is there a case for hybrid systems and intermediate technologies? Rec Manage J. 2018;28:1-14. doi:10.1108/RMJ-02-2018-0004

216 English M, Irimu G, Agweyu A, Gathara D, Oliwa J. Building Learning Health Systems to Accelerate Research and Improve Outcomes of Clinical Care in Low- and Middle-Income Countries. PLoS Med. 2016;14:e1001991. Medline:27070913 doi:10.1371/journal.pmed.1001991

217 Patel A, Prakash AA, Pusdekar YV, Kulkarni H, Hibberd P. Detection and risk stratification of women at high risk of preterm birth in rural communities near Nagpur, India. BMC Pregnancy Childbirth. 2017;17:311. Medline:28927395 doi:10.1186/ s12884-017-1504-4

218 Cluver CA, Hannan NJ, van Papendorp E, Hiscock R, Beard S, Mol BW, et al. Esomeprazole to treat women with preterm preeclampsia: a randomised placebo controlled trial. Am J Obstet Gynecol. 2018;219:388.e1-388.e17. Medline:30055127 doi:10.1016/j.ajog.2018.07.019

219 Ndibazza J, Muhangi L, Akishule D, Kiggundu M, Ameke C, Oweka J, et al. Effects of Deworming during Pregnancy on Maternal and Perinatal Outcomes in Entebbe, Uganda: A Randomized Controlled Trial. Clin Infect Dis. 2010;50:531-40. Medline:20067426 doi:10.1086/649924

220 Ponmozhi G, Keepanasseril J, Mathaiyan J, Manikandan K. Nitric Oxide in the Prevention of Pre-eclampsia (NOPE): A Double-Blind Randomized Placebo-Controlled Trial Assessing the Efficacy of Isosorbide Mononitrate in the Prevention of Pre-eclampsia in High-Risk Women. J Obstet Gynaecol India. 2019;69:103. Medline:31686742 